UII norden

Future of biodiversity in the Barents Region 

2 norden 



\section{Future of biodiversity in the Barents Region}

Anouschka R. Hof, Roland Jansson and Christer Nilsson 
Future of biodiversity in the Barents Region

Anouschka R. Hof, Roland Jansson and Christer Nilsson

ISBN 978-92-893-3988-9 (PRINT)

ISBN 978-92-893-3990-2 (PDF)

ISBN 978-92-893-3989-6 (EPUB)

http://dx.doi.org/10.6027/TN2015-519

TemaNord 2015:519

ISSN 0908-6692

(C) Nordic Council of Ministers 2015

Layout: Hanne Lebech

Cover photo: Anouschka Hof

Print: Rosendahls-Schultz Grafisk

Copies: 30

Printed in Denmark

This publication has been published with financial support by the Nordic Council of Ministers. However, the contents of this publication do not necessarily reflect the views, policies or recommendations of the Nordic Council of Ministers.

www.norden.org/en/publications

\section{Nordic co-operation}

Nordic co-operation is one of the world's most extensive forms of regional collaboration, involving Denmark, Finland, Iceland, Norway, Sweden, and the Faroe Islands, Greenland, and Åland.

Nordic co-operation has firm traditions in politics, the economy, and culture. It plays an important role in European and international collaboration, and aims at creating a strong Nordic community in a strong Europe.

Nordic co-operation seeks to safeguard Nordic and regional interests and principles in the global community. Common Nordic values help the region solidify its position as one of the world's most innovative and competitive.

\section{Nordic Council of Ministers}

Ved Stranden 18

DK-1061 Copenhagen $\mathrm{K}$

Phone (+45) 33960200

www.norden.org 


\section{Content}

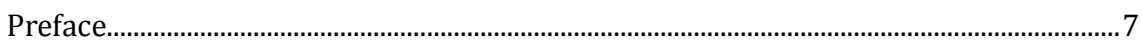

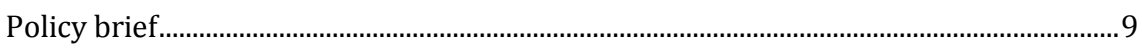

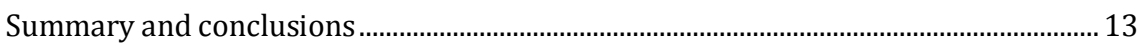

Conclusion and Recommendations ............................................................................ 14

Declining and vanishing species.................................................................................... 15

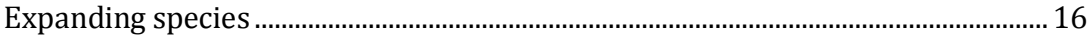

Newly establishing and invasive species......................................................................... 16

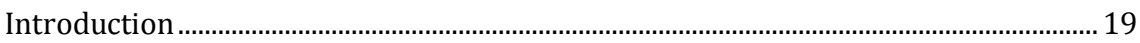

Background and Objectives.............................................................................................. 19

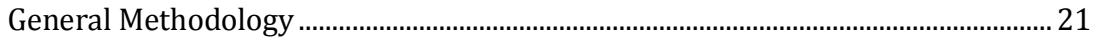

Limitations of the methodology used........................................................................... 26

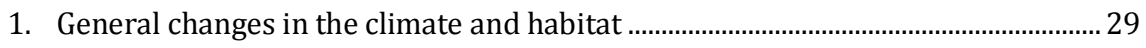

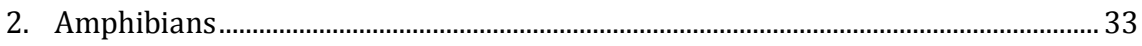

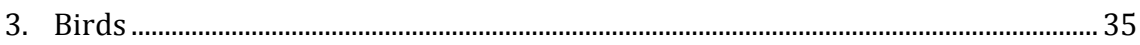

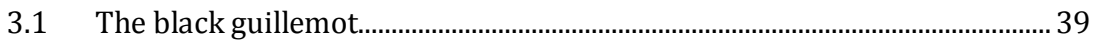

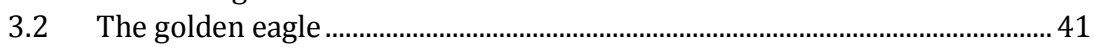

3.3 The spotted nutcracker .................................................................................... 47

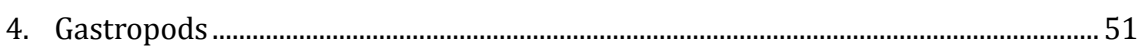

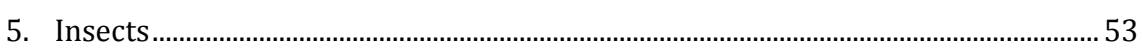

5.1 Possible pest species in the Swedish boreal forest ........................................ 55

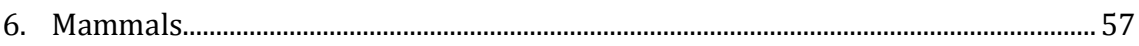

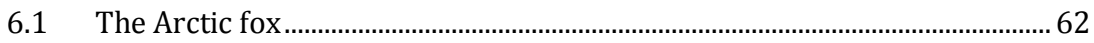

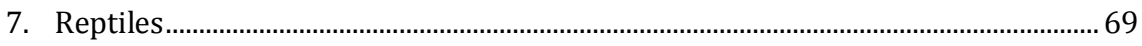

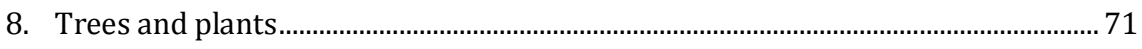

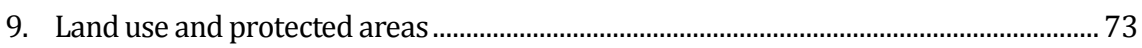

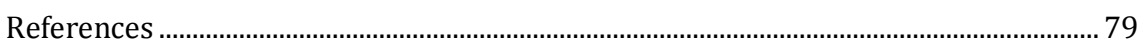

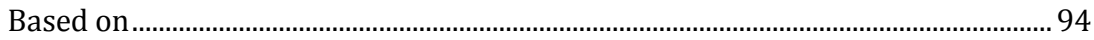

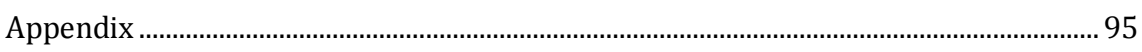

\section{List of figures}

Figure 1. The study area, with the Barents Region........................................................24

Figure 2. Changes in mean annual precipitation and mean annual temperature.........31

Figure 3. The mean annual temperature in $1950-2000$ and 2080 .................................32

Figure 4. The mean annual precipitation in 1950-2000 and 2080 ................................33

Figure 5. Proportion of the main vegetation types. ..........................................................34

Figure 6. Location of the main vegetation types .................................................................34

Figure 7. Current and future predicted potential distribution of common toad...........35

Figure 8. Proportion habitat specialists winner and loser birds ....................................37 
Figure 9. Representation orders winner and loser birds

Figure 10. Percentage area suitable for breeding for birds in 2000 and in $2080 \ldots . . . .39$

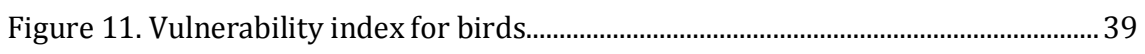

Figure 12. Predicted shift global breeding range black guillemot................................... 42

Figure 13. Current and future suitable areas for golden eagle....................................... 45

Figure 14. Area suitable for the golden eagle with low wind speeds..............................4 47

Figure 15. Area most suitable for wind farms .................................................................. 48

Figure 16. Current, future and stable geographic range of slender-billed nutcracker

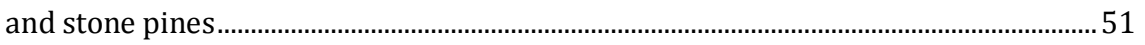

Figure 17. Mean range contraction/ expansion of loser and winner gastropods.........54 Figure 18. Percentage of the Barents Region covered by the geographic distributions of losers and winners at present and in 2070 ..................................................................5 Figure 19. Predicted current extent of boreal needle leaved forest in Sweden affected by the European spruce bark beetle. ..................................................................................... 58 Figure 20. Potential extent of boreal needle leaved forest in Sweden to be affected by the European spruce bark beetle in future...........................................................................58

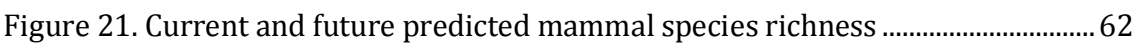

Figure 22. Change in suitability for mammals to occur from present to $2080 \ldots . . . . . . . . . .63$

Figure 23. Former and current distribution range of the arctic fox .................................66

Figure 24. Current and future predicted range of the arctic fox......................................67

Figure 25. Example of how not accounting for species interactions may affect

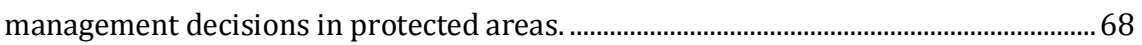

Figure 26. Future climatic suitability of the Barents Region for the sand lizard ..........72

Figure 27. Area of the Barents Region suitable for plants in 2000 and in 2080 ..........74

Figure 28. The fate of the species assessed ....................................................................... 75

Figure 29. Percentage Barents Region covered by geographic distribution ranges of

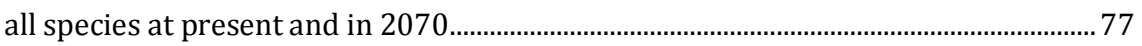

Figure 30. Most important predictor variables for species presence ............................. 77

Figure 31. Areas that may need conservation prioritization ........................................... 79

\section{List of tables}

Table 1. Bioclimatic variables used in the species distribution models

Table 2. The results of the assessment of the impact of climate change on the geographical distribution of a) amphibians, b) birds, c) butterflies and moths, d) mammals, and e) reptiles 95 


\section{Preface}

It is currently well know that climate change may affect biodiversity to a large extent. Its effects have already caused shifts in species distributions and even species' extinctions. Since especially high latitude regions are expected to be affected by climate change, we felt it necessary to assess the impact of future climate change on the biodiversity in these regions. By doing so we would be able to aid decision makers and stakeholders in nature conservation planning. The overarching aim of this project was therefore to evaluate the effectiveness of protected areas that are currently present in the Barents Region in conserving species and ecosystems in a future situation with a warmer climate, and to assess the effect of predicted increases in anthropogenic pressures and land-use changes on future species communities. The climate projections used in this study were the downscaled general circulation model CGCM2, developed by the Canadian Centre for Climate Modelling and Analysis, under emission scenarios A2 and B2 for the year 2080. The A2 scenario considers an important future population growth with elevated primary energy use leading to high greenhouse gas emissions, whilst the B2 scenario is based on the assumption that there will be local solutions to economic, social, and environmental sustainability. It assumes low rates of continuously increasing global population, intermediate levels of economic development, and relatively slow and diverse technological change. The scenario is also oriented toward environmental protection and social equity. However, since climate projections were updated during the course of the study, for some projects the 4.5 and 8.5 Representative Concentration Pathways (RCPs) of the downscaled general circulation model HadGEM2-ES, developed by the Hadley Global Environment Model- Earth System for the year 2070 were used. The RCP 4.5 scenario is based on the assumption that the total radiative forcing is stabilized soon after 2100 . The RCP 8.5 scenario is based on the assumption that greenhouse gas emissions will be increasing over time and will lead to high greenhouse gas concentration levels.

This project was funded by the Nordic Council of Ministers with additional contributions from environmental agencies in Finland, Norway and Sweden. The project was conducted largely by Anouschka Hof with aid of Roland Jansson and coordinated by Christer Nilsson at the Land- 
scape Ecology Group of the Department of Ecology and Environmental Science of Umeå University between 2010 till 2014. The sole responsibility for the content of this document lies with the authors. It does not necessarily reflect the opinion of the Nordic Council of Ministers. The Nordic Council of Ministers is not responsible for any use that may be made of the information contained therein.

We wish to thank the Nordic Council of Ministers, and the environmental agencies in Finland, Norway and Sweden for funding this project, and the Anna och Nils Håkanssons Stiftelse for funding the project described in section 7.1. We further wish to thank Genoveva Rodríguez Castañeda for contributing to the work in chapter 5, Ana Buchadas for contributing to the work in section 5.1, Celine Cordier for contributing to the work in section 5.2, and Anna Svahlin for contributing to the work in section 7.1. 


\section{Policy brief}

It is currently well know that the climate is changing rapidly. This may not only have large consequences for humanity, it may also affect a large number of species and ecosystems. In fact, species have already responded to recent climate change by for instance adjusting their range towards the poles and upwards in the mountains. The climate will change even more in the Barents Region (northern Norway, Sweden, Finland and Northwest Russia) in future. It is thus expected that species will go "on the move". This will likely lead to the formation of new species communities, since species will not all move in the same direction. Species that have never co-existed may co-exist in future. This means that some species may have to face a large number of predators or competitors in future, whilst others may benefit from a larger number of prey. If we want to be able to conserve the species that are currently occurring in the Barents Region, we need to know which threats they will face in future, which new species (species currently occurring south of the Barents region) they may have to co-exist with in future, which areas will be suitable for their needs in future and if they are able to reach those areas. A project to obtain this knowledge was therefore set up at the Landscape Ecology group of the Department of Ecology and Environmental Science of Umeå University. The project was mostly conducted by Anouschka Hof, assisted by Roland Jansson, coordinated by Christer Nilsson, and funded by the Nordic Council of Ministers.

The specific aims of the project were 1) to assess the impacts of climate change on species in the Barents Region, 2) to evaluate how efficient the existing network of protected areas in the Barents Region is in safeguarding species when they will have to face climate change, 3) to provide guidance and recommendations for adapting ecosystem management and conservation strategies in the Barents Region, and 4) to assess the effect of predicted increases in human caused pressures and land-use changes on future species communities in the Barents Region. These aims were addressed by using a range of modelling techniques, literature reviews, and existing data on species presences, on future climate scenarios, and on landcover in the region. These methods and data allowed us to assess the impact of climate change on approximately 500 species of amphibians, butterflies, birds, mammals, moths, plants, 
slugs, snails, and reptiles. A limited number of species like the Arctic fox and the spotted nutcracker were studied more in depth.

We found first and for all that the Barents Region will in future be more wet and warm than at present and the vegetation will be even more dominated by needle leaved forest. Grasslands especially become very rare. These changes in the climate regime and the habitat availability are expected to lead to an increase in the species richness, but only if species are able to disperse to the area that become suitable for their needs and if they are able to fully utilize the area that will become more suitable. If species are not able to disperse to those newly suitable areas, but are able to persist in the areas they occupy at present, species richness will decrease in future. Since it is unlikely that species are indeed able to fully utilize the area that will become suitable to their needs due to the likely presence of barriers and gaps in their migration routes and due to the limited possibility of a large number of species to quickly disperse, we highly recommend considering increasing the network of protected areas and creating possible dispersal routes to allow species to disperse between the areas they currently occupy and the areas that will be suitable for them to occupy in future. This is especially important because on top of the effects future climate change may have on species, there may be other, species-specific, factors that may make species vulnerable. One can for instance think of species that are vulnerable to the competition of predation by other species that may be benefitted by climate change. One example of such a species is the Arctic fox. The Arctic fox thrives in cold climates. The fact that the Barents Region will become warmer in future is therefore negative for the Arctic fox: less area will be suitable to its needs in future. The same goes for one of its main prey items, the Norway lemming. However, the main competitor of the Arctic fox is the red fox. This species thrives in more temperate climates and will likely be able to shift its range northwards when the Barents Region continues to warm. The Arctic fox will therefore likely have to face deteriorating climate conditions, lower numbers of its favourite prey and higher numbers of its main competitor. Such affects all need to be taken into account when we want to effectively conserve species.

The species that need to be prioritized for conservation are coldclimate specialists and slow dispersing species. They are particularly vulnerable and may even go extinct locally. Areas that need to be prioritized when increasing the network of protected areas are located in the coastal areas of Fennoscandia and in the south-western parts of Northwest Russia. These areas are going to be climatologically increasingly 
suitable for a large number of species. However, these areas also have the highest human activity and political and socio-economic issues may undermine choosing the areas that are predicted to have the highest biodiversity for protection. Organizational, social, economic and logistical factors may overrun ecological choices in practice and although the cost component in conservation priority setting is often neglected, resources are not endless. This calls for managing landscapes and regions to allow the coexistence of humans and other species. More detailed studies that focus on species that need immediate attention, such as a large number of species thriving in cold conditions, in combination with assessments of what is possible economically, politically, logistically and socially is necessary if we want to optimize conservation. 



\section{Summary and conclusions}

The climate is changing rapidly, affecting the distribution and abundance of numerous species. If we want to be able to preserve biodiversity it is paramount that we obtain more knowledge about how climate change may affect the species currently inhabiting the Barents Region, i.e. northern Norway, Sweden, Finland and Northwest Russia, and the species that may in future establish in the region. This project was funded by the Nordic Council of Ministers, conducted at the Landscape Ecology group of the Department of Ecology and Environmental Science of Umeå University and set up with the aims:

- To assess the impacts of climate change on species in the Barents Region.

- To evaluate the efficiency of the existing network of protected areas in safeguarding species in the Barents Region under climate change.

- To provide guidance and recommendations for adapting ecosystem management and conservation strategies in the Barents Region.

- To assess the effect of predicted increases in anthropogenic pressures and land-use changes on future species communities in the Barents Region.

We used a range of modelling techniques and literature reviews to assess the impact of climate change on biodiversity by including approximately 500 species of amphibians, butterflies, birds, mammals, moths, plants, slugs, snails, and reptiles in our study. We furthermore studied several species more in depth. 


\section{Conclusion and Recommendations}

- The Barents Region will in future be more wet and warm than at present. The vegetation will be even more dominated by needle leaved forest whilst grasslands become very rare.

- Species richness may increase in the Barents Region in future if species are able to disperse and fully utilize their future climatic niches. If species are not able to disperse beyond their current climatic niche, but are able to maintain in the areas they occupy at present, species richness will decrease in future. We therefore highly recommend considering increasing the network of protected areas and creating possible dispersal routes to allow species to disperse between their current and future climatic niches.

- On top of the effects future climate change may have on species, species' natural history traits that may be potential risk factors in a warming environment, such as whether species are migratory or not and whether species are vulnerable to predators or not, should be taken into account when designing conservation strategies.

- Cold-climate specialists and slow dispersing species are particularly vulnerable and may even go extinct locally. Possible negative effects of indirect impacts of climate change, such as increased competition and predation, are thought to present great challenges to coldclimate specialists. These affects should therefore not be neglected.

- It is important to consider important species interactions when assessing the vulnerability of a species to climate change. As an example, when a key predator is thought to benefit from climate change, a large number of prey species may significantly be affected as well, irrespective of whether the prey species are thought to benefit from climate change directly or not. Similarly, the potential decrease of important prey species, such as the Norway lemming, may cause the decline of a whole range of predators, irrespective of whether the predators are thought to benefit from climate change directly or not.

- Areas that need to be prioritized when increasing the network of protected areas are located in the coastal areas of Fennoscandia and in the south-western parts of Northwest Russia. These areas are going to be climatologically increasingly suitable for a large number of species. However, these areas also have the highest human activity and political and socio-economic issues may undermine 
choosing the areas that are predicted to have the highest biodiversity for protection.

- Organizational, social, economic and logistical factors may overrun ecological choices in practice and although the cost component in conservation priority setting is often neglected, resources are not endless. This calls for managing landscapes and regions to allow coexistence of humans and other species. More detailed studies focusing on particular species in combination with assessments of what is possible economically, politically, logistically and socially is necessary to optimize conservation.

\section{Declining and vanishing species}

We found that cold-climate specialists are particularly vulnerable to climate change. This is not surprising since the Barents region is thought to become wetter and warmer in future. These species may lose considerable parts of their geographic range in the Barents Region in future and their conservation should be prioritized. Table 2 in the appendix lists all species assessed. Species that deserve immediate extra attention are those for which the models predicted that environmental conditions will no longer be suitable in the region in future. Amongst these were two bird species, the red-flanked bluetail (Tarsiger cyanurus) and the Siberian jay (Perisoreus infaustus), and five butterflies/moths, the dingy fritillary (Boloria improba), the mountain fritillary, (Boloria napaea), the pale Arctic clouded yellow (Colias werdandi), the scarce heath (Coenonympha hero), and the Alpine grizzled skipper (Pyrgus andromedae). We recommend that in focus studies will be undertaken to confirm our findings and to investigate other factors that may present additional problems for these species. Indirect impacts of climate change, such as increased competition and predation, and decreased food availability, may be more severe. Furthermore, there may be a whole other range of threats to the species, such as habitat destruction, hunting, oil spills and other anthropogenic pressures. These threats are likely not limited to the political borders of the Barents Region. Cross-border approaches should therefore be taken. In addition, detailed studies will give better insight in which areas should be conserved on a more detailed scale and which additional actions should be taken. Predator control, provision of extra food, limitations of hunting quota or giving specific species protective statuses may all be worthwhile actions depending 
on the species. In depth studies of the species at threat will provide the necessary knowledge needed to design sound conservation plans and strategies.

\section{Expanding species}

The climatic conditions for the fast majority of the species we assessed in this study are predicted to improve. Species richness is therefore thought to increase in the Barents Region in future. However, we stress that it is not given that species are able to reach their future climatic niches. This is highly dependent on their dispersal ability and on the availability of suitable habitat to disperse through. Although highly dispersive species, such as most birds and bats, are likely well-adapted to colonizing small isolated patches of habitat, even if their habitat requirements are restrictive, most amphibians and reptiles and even a number of mammals, like the hazel dormouse (Muscardinus avellanarius) (Bright 1998), are highly dependent on continuous habitat in order to migrate into new areas. Assisted migration may for a limited number of species be an option, provided that the species will not disrupt existing ecosystems. It is however vital that an extensive network of dispersal corridors that connect protected areas and other suitable regions is in place. Such corridors and new protected areas could best be placed in the coastal areas of Fennoscandia and in the south-western parts of Northwest Russia. However, organizational, social, economic and logistical factors may overrun ecological choices for which areas should receive conservation priority in practice. We therefore recommend investigating possibilities to conserve areas in a collaborative platform of ecologists, social and political scientist, practitioners and other stakeholders enveloping all participating countries in the Barents Region.

\section{Newly establishing and invasive species}

A large number of species currently inhabiting areas south of the Barents Region may be able to colonize the region in future because environmental conditions will become suitable. Effects of species that may be able to establish themselves in existing communities are thought to present greater challenges to native species than direct effects of climate (Callaghan et al. 2004; Hoffmann et al. 2010; Hof et al. 2012a). Although not all these species are likely to become invasive, climate 
change may promote invasiveness (Bellard et al. 2012). Invasive alien species have been one of the major causes of species' extinctions in the past and drive, together with habitat loss and fragmentation, presentday species' extinctions (Hoffmann et al. 2010). Climate-driven invasions of species may transform ecosystems to such a degree that alien species become dominant and the diversity of native species decreases (Gritti et al. 2006; Mack et al. 2000). We predict that a number of pest species, like wood boring beetles and moths, may be more widespread in future. In addition, some plant and tree species, like stone pines ( $\mathrm{Pi}$ nus sp.) and the European silver fir (Abies alba), are thought to become more widespread and they are currently already classified as invasive in parts of the Barents Region.

However, all species can become invasive, i.e. they have the potential to spread over a considerable area in large abundances, irrespective of whether they were already present in the Barents Region or whether they will be able to establish themselves in future (Cornelissen et al. 2001). But, they may also contribute towards ecosystem recovery by fulfilling important ecosystem functions or by providing ecosystem services when native species become less adapted (Walther et al. 2009; Bertness and Coverdale 2013). Moreover, aliens may lose their native range due to climate change, making the new established area their only chance for survival. Alien species cost the world's economies a lot of money each year according to the Convention on Biological Diversity (http://www.cbd.int/invasive/), and likely even more in future. Dilemmas with regard to appropriate conservation and management of species will therefore be increasingly common, especially since it is not straightforward to recognise which species will be invasive (Mack et al. 2000), and which will fulfil important ecosystem functions or provide ecosystem services when native species become less adapted. Further research thus needs to be aimed at assessing for each species whether their arrival has negative or positive impacts on native species or ecosystem functions and services. We need to know and understand their impacts, and future role, in our ecosystem, since resources are not endless. 



\section{Introduction}

\section{Background and Objectives}

It is currently well known that the climate is changing rapidly (IPCC 2007). The predicted impact of climate change is thought to be large scale and capable of affecting entire ecosystems, since the geographic distribution of terrestrial ecosystems is ultimately shaped by climatic factors such as temperature and precipitation (Woodward 1987). Especially the high latitude regions in the northern hemisphere are expected to be affected by amongst others an increasing winter temperature (IPCC 2007; ACIA 2005). Indeed, it is undeniable that the climate in the arctic region has changed over the last few decades (Serreze et al. 2000; Peterson et al. 2002; Serreze et al. 2003). Various climate change models predict significant changes in northern areas. Roderfeld et al. (2008), for instance, predict that the tundra climate will decrease and the temperate climate types will extent to the north in future (also see Callaghan et al. 1995; Kullman 2002). Moreover, the European part of the Subarctic and Arctic regions, i.e. the Barents Region is the most geographically complex with the most infrastructure and great cultural, social, and political heterogeneity (Nilsson et al. 2010).

The threat of a changing climate has been recognised as one of the main drivers behind (future) extinctions (Markham 1996; Thomas et al. 2004). Species extinctions and range retractions instigated by climate change are occurring at a large scale (Thomas et al. 2006). Loarie et al. (2009) estimate that climatic niches shift polewards with on average $0.42 \mathrm{~km} \mathrm{yr}^{-1}$ under the A1B emission scenario, which will require species to either adapt to new climatic conditions or migrate at a similar pace. Since climate change is occurring at a rapid rate (IPCC 2007), it seems that climate tracking is imperative for the survival of a large range of species. Evidence shows that species already have responded to climate change by adjusting their range (Parmesan et al. 1999; Thomas et al. 2001; Walther et al. 2002; Parmesan and Yohe 2003; Karban and Strauss 2004). An increasing number of changes in species' geographic distributions are expected in future (Hill et al. 2002; Thuiller 2004). Although the capacity of species to quickly adapt to new climatic conditions should not be underestimated (Hof et al. 2011), the ability to adapt depends amongst others on 
the amount of genetic variation in populations and their physiological sensitivity to climate change (Chown et al. 2010; Davis and Shaw 2001). Habitat fragmentation generally lowers the diversity of gene pools in populations which might augment stress caused by climate change (Joubert and Bijlsma 2010). Existing protected areas, especially small ones, will likely not suffice to conserve a number of species that presently inhabit them in future (Loarie et al. 2009; Araújo et al. 2011).

A changing climate will together with ongoing habitat fragmentation increase the stress upon species, especially on those with a limited capacity for dispersal. When species are unable to track their climatic niche or adapt to changing environments, extinctions may occur (Thomas 2004; Opdam and Wascher 2004). In fact, Warren et al. (2001) found that, in spite of increasing areas of favourable conditions, populations of butterflies with a low dispersal capacity declined, which lead to the believe that for these populations the effect of habitat fragmentation was stronger than the effect of a changing climate. Since climate change is expected to be especially large at high northern latitudes (Sala et al. 2000), species inhabiting the Barents Region might face considerable challenges in tracking their climate niche. Although it is expected that, for instance, a large number of mammals inhabiting the Barents Region might experience range expansions in a future warmer climate (Hof et al. 2012b), it is not necessarily true that species will actually be able to colonize their future ranges. Although many arctic species are capable of coping with direct effects of climate change such as increased temperature and UV-B radiation, indirect effects, such as increased competition and predation, are likely going to have a larger impact and should therefore not be underestimated (Callaghan et al. 2004).

To conserve biodiversity it is imperative to have a good understanding of where species will be in the future. The main aim of this project was therefore to assess how future climate change will affect the distribution of species currently inhabiting the Barents Region as well as species that may colonize the region in the future. We focus on many taxa, including mammals, birds, reptiles, amphibians, insects, gastropods and plants. We further aimed to get a better understanding of where future biodiversity hotspots may be and subsequently which areas may need extra protection and/or changes in ecosystem management. 


\section{General Methodology}

We used the species distribution modelling (SDM) algorithm MaxEnt (Phillips et al. 2006) to predict the current and future (2070) geographic ranges of a large number of species. SDMs are widely used to predict the impact of climate change on species distributions (e.g. Virkkala et al. 2010; Araújo et al. 2011). The general approach of SDMs is to identify important variables amongst those entered in the model that strongly correlate with species occurrences. Largely based upon those variables that determine most of the variation in species presence, SDMs predict the highest likelihood of species presence throughout a defined region in a specific time (Phillips et al. 2006). Maxent only needs presence records to generate predictions, absence records are taken randomly from the extent of the geographic region used to train the model (Phillips et al. 2006, Elith et al. 2011). However, different results may be obtained when using different geographical extents (Anderson and Raza 2010), because the range and diversity of conditions where the species is absent vary. Using a large extent, meaning that there is a large variety in the climatic conditions used to generate predictions, can lead to overestimating the area suitable for a species. On the other hand, when a small geographic extent is used, one risks that the breadth of the climatic conditions used to generate the prediction does not capture the full climatic niche of the species of concern. This leads to underestimations (Thuiller et al. 2004). Although our study site was limited to the Barents Region, the area that we modelled included an additional zone of approximately 1,000 km south of the study site (indicated in Figure 1), since many species are expected to shift or expand their geographic ranges to higher latitudes (Parmesan et al. 1999). In this way we were able to include many possible colonizers, presently occupying climatic conditions that may appear in the Barents Region in the future.

We collected occurrence data for the species assessed for the period 2000-2010 from national species occurrence databases such as the Norwegian Artsobservasjoner (http://www.artsobservasjoner.no), the Swedish Artportalen (http://www.artportalen.se), and the Finnish Hattika [http://www.hatikka.fi]), and from the data portal of the Global Biodiversity Information Facility (http://data.gbif.org). Species occurrences for birds were limited to the breeding season (set to JuneAugust). Occurrence data collected by citizen scientists are often biased due to, amongst others, misidentifications and geographic differences in sampling intensity. 
Figure 1. The study area, with the Barents Region

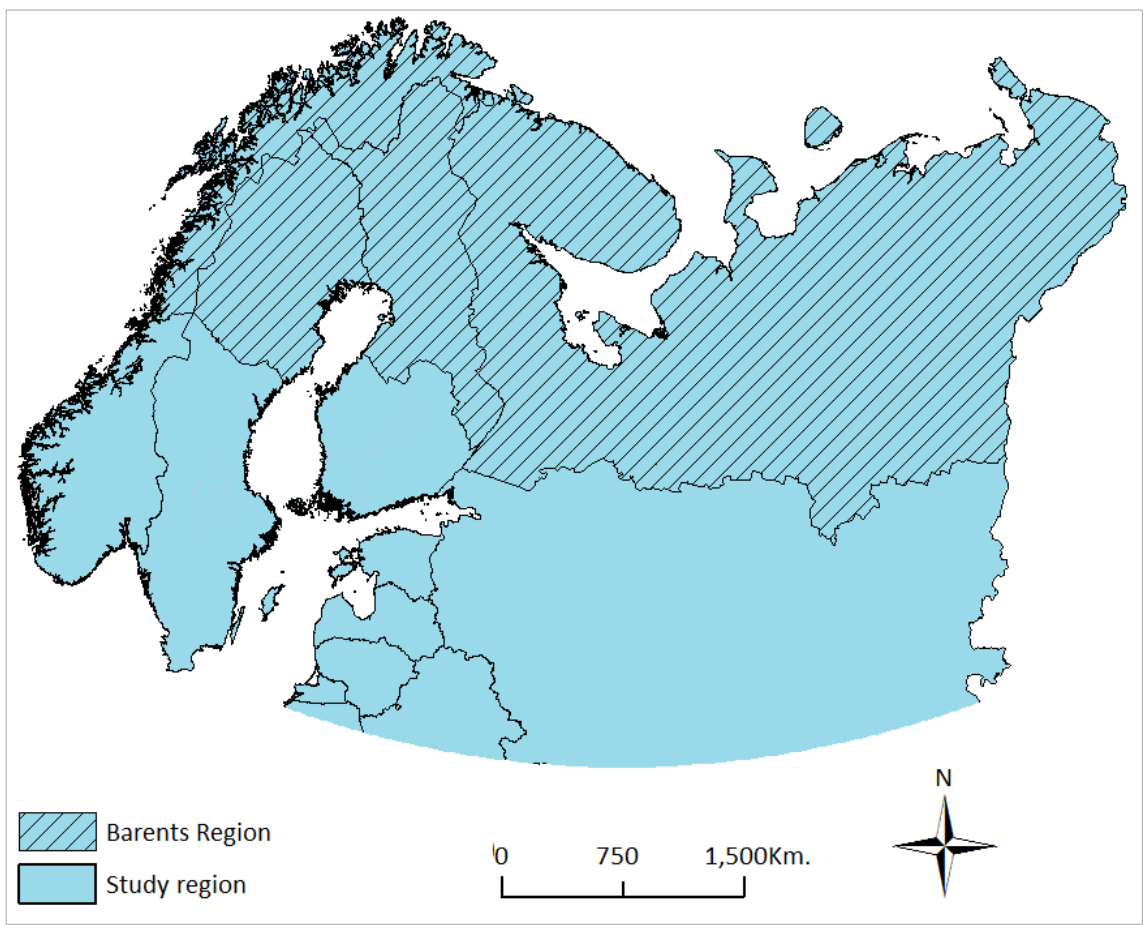

Unfortunately, it is not possible to identify potential misidentifications in databases collected by citizen scientists. Detailed occurrence data from Northwest Russia were highly limited and often non-existent in comparison to Fennoscandia. In order to reduce sampling intensity bias, we randomly deleted occurrences in over-sampled areas, such as near cities, by using a raster larger than the scale of the further analyses (grid size $10 \mathrm{~km}^{2}$ vs. $\sim 1 \mathrm{~km}^{2}$ ) with the aim of having only one randomly chosen occurrence per grid-cell. This approach does not deal with under-sampled areas (i.e., Northwest Russia), implying that the full environmental ranges of the species were not captured. Setting the extent of the environmental variables to the entire study area (including Northwest Russia) in the distribution models led to conservative predictions of current species distributions in comparison to the ranges suggested by the IUCN, since the model assumed that environmental conditions in Northwest Russia were not suitable for the species. Severe under-prediction is a grave error in the context of climate change, and excluding Northwest Russia in the extent of the environmental variables led to more accurate current predictions in comparison to the IUCN-ranges. Therefore, predictions for current situations in Northwest Russia and for future were based on the extent of the environmental variables and the occurrence data from Fennoscandia (Rodríguez-Castañeda et al. 2012). 
A number of climate projections were used. For the majority of the studies the downscaled general circulation model CGCM2, developed by the Canadian Centre for Climate Modelling and Analysis, under emission scenarios A2 and B2 for the year 2080 were used (http://www.worldclim.org). The A2 scenario considers an important future population growth with elevated primary energy use leading to high greenhouse gas emissions, whilst the B2 scenario is based on the assumption that there will be local solutions to economic, social, and environmental sustainability. It assumes low rates of continuously increasing global population, intermediate levels of economic development, and relatively slow and diverse technological change. The scenario is also oriented toward environmental protection and social equity (Nakicenovic et al. 2000). However, since climate projections were updated during the course of the study, for some projects the 4.5 and 8.5 Representative Concentration Pathways (RCPs) of the downscaled general circulation model HadGEM2-ES (Hadley Global Environment Model- Earth System) for the year 2070 were used. The RCP 4.5 scenario is based on the assumption that the total radiative forcing is stabilized soon after 2100 . The long-run radiative forcing target level will not be surpassed (Thomson et al. 2011). The RCP 8.5 scenario is based on the assumption that greenhouse gas emissions will be increasing over time and will lead to high greenhouse gas concentration levels (Riahi et al. 2011). Nineteen bioclimatic variables derived from monthly temperature and rainfall values during 1950-2000, described and available at http://www.worldclim.org, were used in all models (also see Table 1). Since species distributions can largely be determined by habitat type in addition to climatic conditions, we included habitat related variables in the modelling for 2080 only since data for 2070 were not available. We used projections of the main vegetation zones (boreal needle leaved forests, grasslands, shrub areas, and shade intolerant broadleaved forests) for 1990 and 2080 (Wolf et al. 2008). A dynamic vegetation model (LPJ-GUESS) was used to project transient impacts of changes in climate on vegetation of northern Europe; the resulting vegetation projection provided continuous data of biomass of the main vegetation zones. The climate data from WorldClim were available at the 30 arc-seconds $\left(\sim 1 \mathrm{~km}^{2}\right)$ scale. The vegetation data were available at the 25 arc-minutes scale and interpolated to the 30 arc-seconds scale in ArcGis (9.3.1 by ESRI) by means of the natural neighbour method.

For many species climate, vegetation cover, and anthropogenic factors largely determine their geographic distribution. Since habitat 
data for 2070 was not available we included landcover, available at the 30 arc-seconds scale from the Global landcover Facility (http://www.landcover.org), and also human population density (http://edit.csic.es/), in the models for 2070 as static variables. Unfortunately predictions of future land use available for the Barents Region are not available for the latest generation of climate projections. When contacted, the developers of these scenarios lacked confidence in the projections themselves. We therefore had to resort to including these data as static variables, which is not uncommonly done to represent anthropogenic impacts in predictive studies (Algar et al. 2009; Morueta-Holme et al. 2010). Furthermore, a number of species, especially birds, were associated with coastal environments. The distance to the coast was therefore entered in the models as a static variable in order to avoid inland areas being predicted as suitable for coastal species.

Table 1. Bioclimatic variables used in the species distribution models

\begin{tabular}{ll}
\hline Variables & Explanation \\
\hline BIO 1 & Annual mean temperature \\
BIO 2 & Mean diurnal range (mean of monthly (maximum temperature - minimum temperature)) \\
BIO 3 & Isothermality (BIO2/BIO7 * 100) \\
BIO 4 & Temperature seasonality (standard deviation * 100) \\
BIO 5 & Maximum temperature of warmest month \\
BIO 6 & Temperature annual range (BIO5-BIO6) \\
BIO 7 & Mean temperature of wettest quarter \\
BIO 8 & Mean temperature of driest quarter \\
BIO 9 & Mean temperature of warmest quarter \\
BIO 10 & Annual precipitation \\
BIO 11 & Precipitation of wettest month \\
BIO 12 & Precipitation of driest month \\
BIO 13 & Precipitation seasonality (coefficient of variation) \\
BIO 14 & Precipitation of wettest quarter \\
BIO 15 & Precipitation of driest quarter \\
BIO 16 & Precipitation of warmest quarter \\
BIO 17 & Precipitation of coldest quarter \\
BIO 18 & \\
BIO 19 &
\end{tabular}

We did not pre-select variables, taking advantage of the regularization application of MaxEnt, which deals with the selection of environmental variables (regulating some to zero). This application has shown to perform well and is thought to outperform other pre-selecting procedures (Hastie et al. 2009; Elith et al. 2011). MaxEnt uses a continuous scale to predict the suitability of a region. This was transformed into binary suitable/unsuitable area by applying a cut-off threshold where the difference between sensitivity and specificity was minimized (Liu et al. 2005). The extent of, and overlap between, the current and the predicted future ranges were calculated in ArcGIS 9.3. The Area Under the Curve (AUC) of a 
Receiver Operating Characteristic (ROC) plot (Phillips et al. 2006) was used to assess the accuracy of the predictions of species distribution models. The AUC is a discrimination index. It shows the likelihood that an area with a species occurrence will receive a higher suitability value than an area where there is no species occurrence. However, this is regardless of the goodness-of-fit of the model and dependent on the predictor variables entered in the model. In other words, the AUC shows the ability of the model to discriminate between areas that are suitable for a species to occur versus areas that are not, based on the predictor variables (Phillips et al. 2006). In addition, by means of randomized partition, $30 \%$ of the occurrence data were set aside as testing data in order to compare the AUC of these models with that of the training models, which consisted of the remaining $70 \%$ of the occurrence data. Statistical analyses were performed in R version 3.0.2 (R Core Development Team 2014). The Welch Two Sample t-test was used to compare model performances.

For the purpose of the analyses in section 10 we used the software Zonation v.4 (Moilanen et al. 2005, 2009) to identify which areas should receive priority for conservation. Zonation is a spatial conservation planning method which for instance is specifically designed for the prioritization of geographical areas for conservation, and has frequently been used in conservation planning (e.g. Carroll et al. 2010). The software identifies areas that are important for a multitude of species and ranks areas in the study region hierarchically for conservation priority depending on first of all the suitability of areas for species, but may also depend on for instance the importance of species, as set by the user, and connectivity to other suitable areas in space or in time. First, we obtained prioritization for conservation of current species hotspots to assess the current protected area network. Second, we obtained prioritization for conservation of future species hotspots.

We also considered connectivity between current and future species hotspots by prioritizing both current and future hotspots, and connectivity between them. Higher weights were assigned to species currently listed on the European Red List and to species predicted to lose part of their geographical range in the study region due to climate change, based upon the predictions by Maxent. We chose the European list rather than a country specific list as a species can be classified differently depending on the country. Based upon recommendations on the weighing of species by Lehtomäki and Moilanen (2013), all species predicted to expand their geographical range in the study region in future and assessed as least concern were given an aggregated weight of 10. All species predicted to expand their geographical range and assessed as 
near threatened got an aggregated weight of 15, those assessed as vulnerable 20 , as endangered 25 , and critically endangered 30 . All species predicted to lose part of their geographical range in the study region in future and that were assessed as least concern were given an aggregated weight of 15. All species predicted to lose part of their geographical range and assessed as near threatened an aggregated weight of 20 , those assessed as vulnerable 25 , as endangered 30 , and critically endangered 35. This, to some extent arbitrarily, weighing was chosen as such since we thought it most important to conserve the species that currently are and predicted to be most vulnerable in future.

We applied the core-area Zonation, which emphasizes species rarity (Lehtomäki and Moilanen 2013). Since fragmentation of suitable landscape may largely determine the capacity of species to track their environmental niche through time, we gave priority to aggregated and connected sites by using the "Boundary Length Penalty" option in Zonation (Moilanen and Wintle 2007). Cells that increase the length of the boundary - these cells are on the edge of a suitable area - and therefore increase fragmentation, are removed before cells that do not increase the length of the boundary - these cells are within the suitable area.

\section{Limitations of the methodology used}

The main limitation of the use of SDMs is the assumption that species' ranges are determined mostly by climate due to the limited possibility to introduce many other biotic and abiotic factors in such models. Future predictions of, for instance, food availability are usually not available and species interactions can frequently not be included. This is often inherent for studies that apply SDMs to get a better understanding of the impact of climate change on species distributions' (Engler et al. 2009, Anderson and Raza 2010, Barve et al. 2011). Another limitation of the use of SDMs is that they indicate where in space and in time conditions are similar to where species have been found. It must therefore be noted that the accuracy of predictions generated by SDMs is highly dependent on the availability of accurate species occurrence data. Although we made an effort to reduce potential bias present in the datasets, due to the low number of occurrences of some species and patchy availability of data for other species, predictions should be seen as an indication of higher likelihood of presence/absence rather than as a factual presence/absence. Furthermore, there are multiple other factors that drive the distribution of species. We did for instance not account for the dispersal rate of species, usually only 
modelling either full or no dispersal. The dispersal rates for many species are often unknown, poorly documented or highly temporally and spatially variable and when the purpose is to get a general idea of species richness in an area it is logistically not feasible to account for dispersal rates. Due to these limitations predictions generated by SDMs show the potential niche based on the input variables - i.e. if only climatic variables are used, then the climatic niche of a species will be predicted - and not necessarily the realized niche of a species, which is important to keep in mind when interpreting resulting predictions.

Furthermore, as our main aim was to assess the impact of climate change on biodiversity, and since there are many species present in the Barents Region but there was a limited amount of time and resources, we had to use an approach producing general results from a representative set of species. We studied a limited number of species more in detail, such as the Arctic fox (Vulpes lagopus), but it was not logistically feasible to place such a detailed focus on each species. The results should therefore be seen as general trends and to obtain the best possible predictions for specific species, more study is needed, since for the majority of species possible indirect impacts of climate change, such as changes in predation pressure, competition and food availability were not taken into account. 



\section{General changes in the climate and habitat}

The Barents Region will become warmer and wetter in future according to the expectations (Figure 2). In 2080 it is expected to be on average $5.0^{\circ} \mathrm{C}$ warmer than in the period between 1950 and $2000\left(\mathrm{~min} .2 .7^{\circ} \mathrm{C}\right.$, max. $6.7^{\circ} \mathrm{C}$ ). Furthermore, in 2080 the expected annual precipitation has risen with on average $69 \mathrm{~mm}$, with a minimum of $23 \mathrm{~mm}$, and a maximum of $278 \mathrm{~mm}$ extra precipitation in comparison to 1950-2000.

According to the CGCM2 model under emission scenario A2 there will be hardly any area left in future with an annual mean temperature lower than $-2.5^{\circ} \mathrm{C}$ (Figure 3). Similarly, there will be hardly any area where the annual mean temperature does not rise above $0{ }^{\circ} \mathrm{C}$. Only the high mountainous region on the border between Norway and Sweden and the far east of the Barents Region will on average remain below $0{ }^{\circ} \mathrm{C}$ throughout the year. Most of the region will have an annual mean temperature of above $5^{\circ} \mathrm{C}$. In addition to rising temperatures, the Barents Region will also become wetter in future (Figure 2). Based on the CGCM2 model under emission scenario A2 there will less area in the region with an annual precipitation of less than $500 \mathrm{~mm}$. These areas will mostly be in northern Norway and in the north of the Russian part of the Barents Region (Figure 4).

Figure 2. Expected changes in the mean annual precipitation and the mean annual temperature between 1950-2000 and 2080 according to the CGCM2 model under emission scenario $A 2$

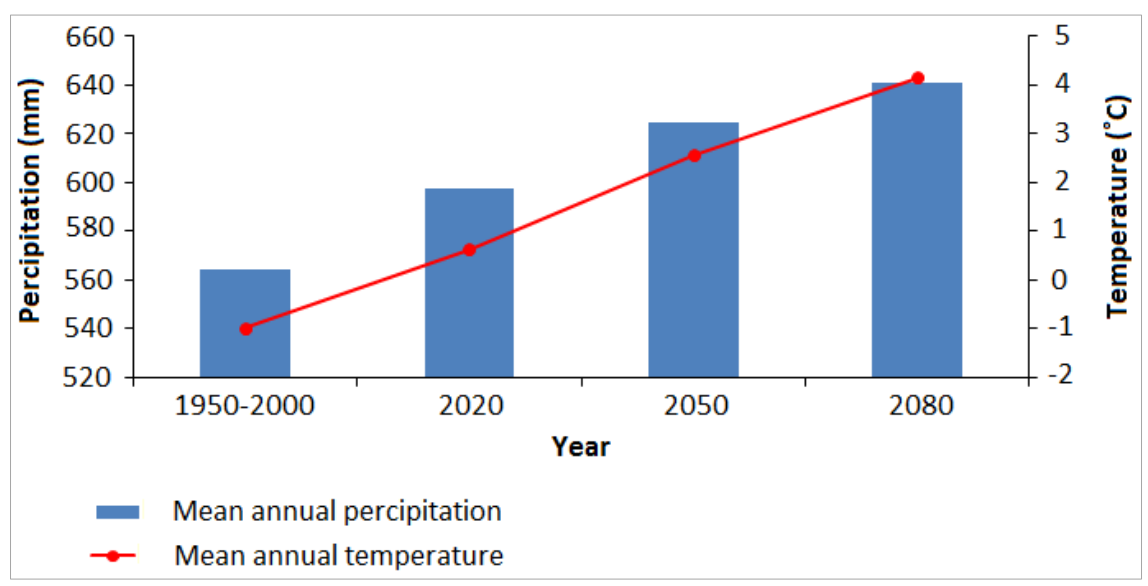


Figure 3. The mean annual temperature for the period 1950-2000 and expected in 2080 according to the CGCM2 model under emission scenario A2

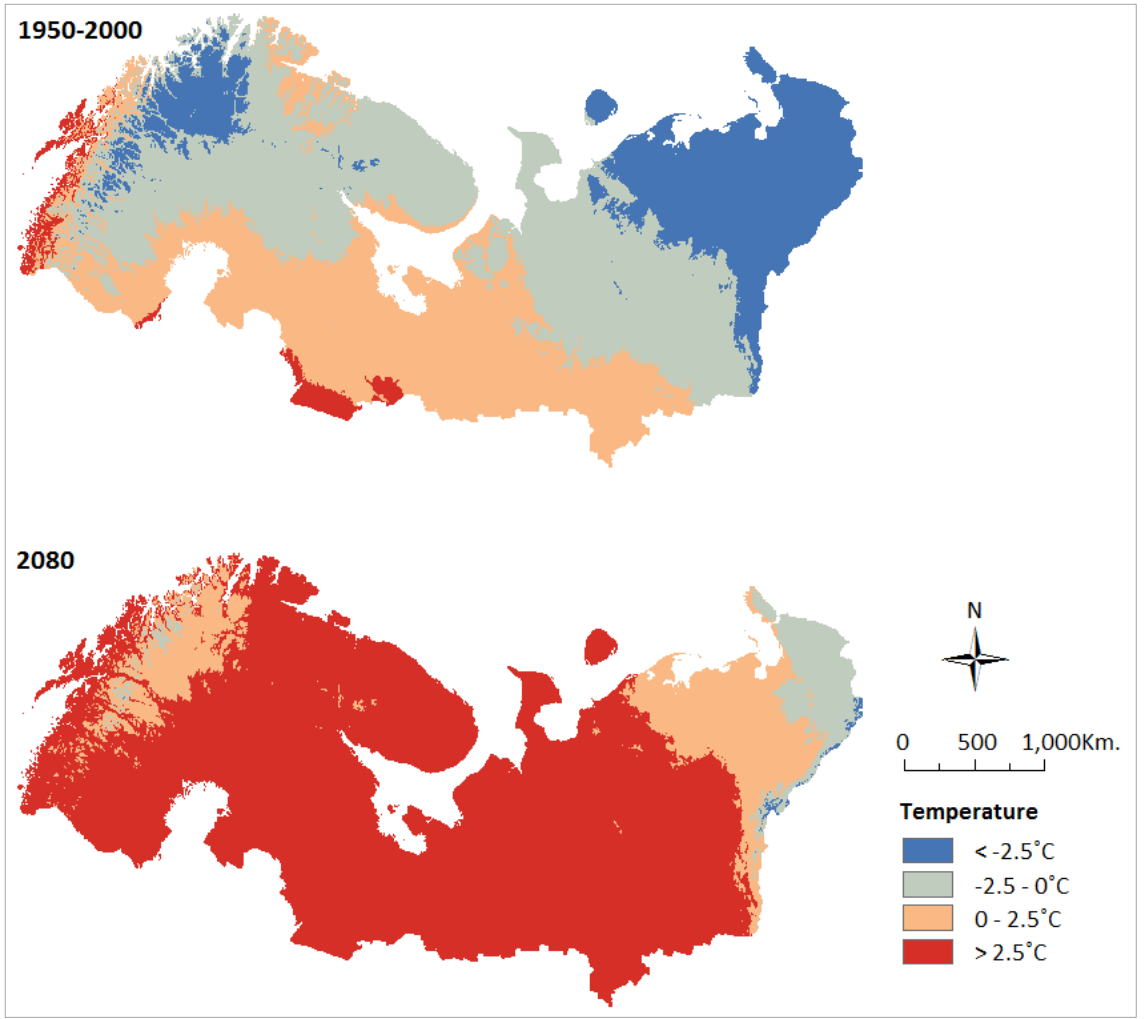


Figure 4. The mean annual precipitation for the period 1950-2000 and expected in 2080 according to the CGCM2 model under emission scenario A2

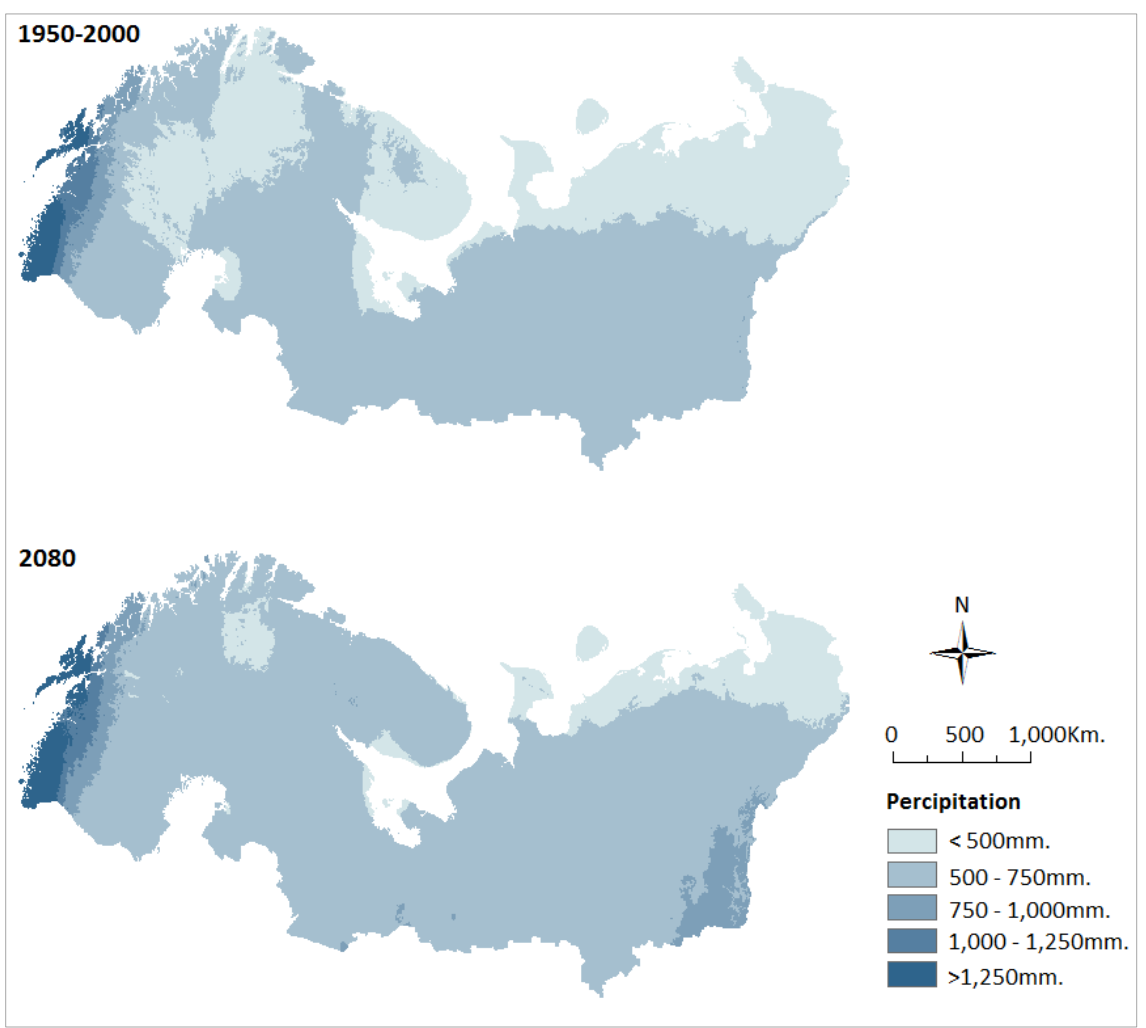

The total area of habitat types represented in the Barents Region differed between 1990 and 2080 (Figure 5). Needle leaved forest will become more dominant in the region on expense of broadleaved forest, grassland and shrubs. These vegetation types are moving upwards in altitude and northwards in latitude (Figure 6). Already now there is not much grassland and by 2080 , hardly any is expected to remain. 
Figure 5. Proportion of the main vegetation types present in the Barents Region in 1990 and in 2080

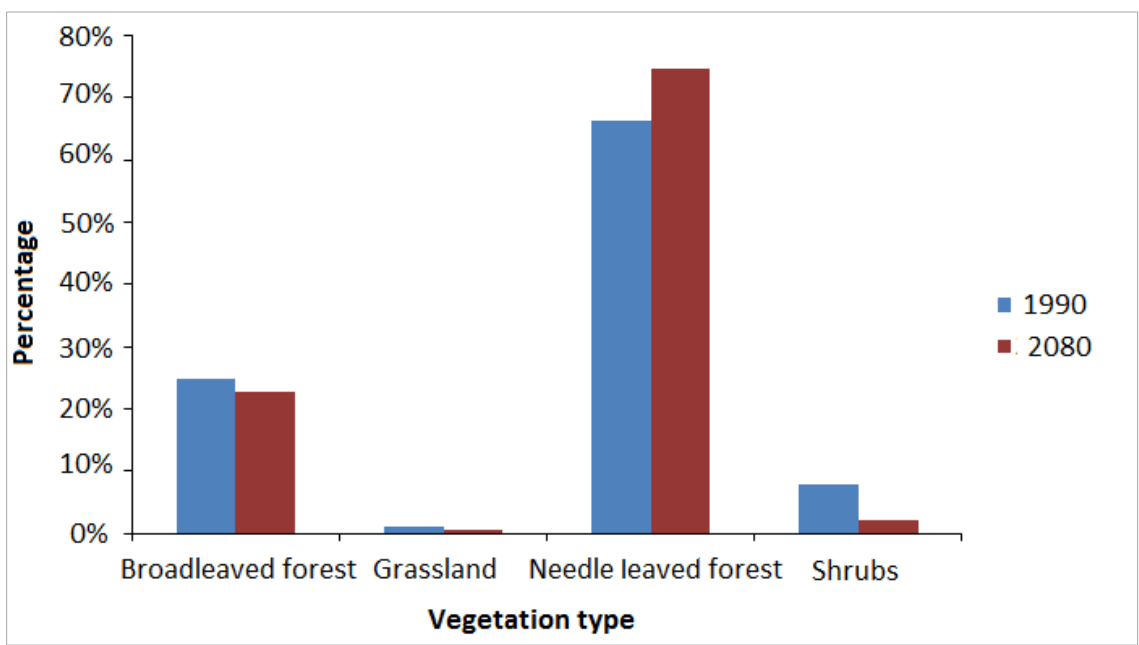

Wolf et al. 2009.

Figure 6. Location of the main vegetation types in 1990 and in 2080

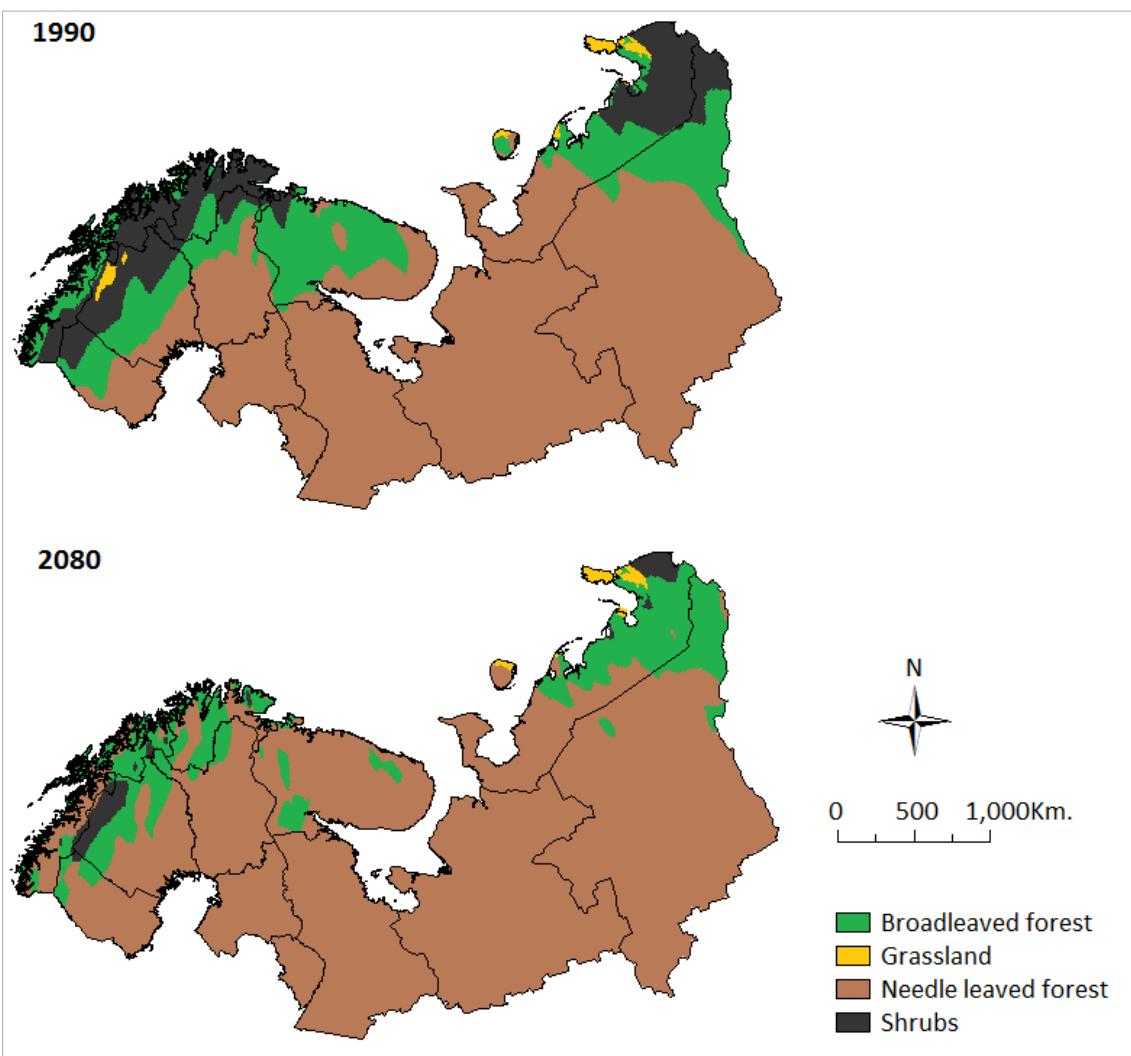

Wolf et al. 2009 


\section{Amphibians}

Amphibians are ectotherms. This means that they rely on environmental heat sources like the sun to regulate their body temperature to a large extent. Changes in the climatic regime therefore generally have large effects on the development, spatial distribution, and species interactions of and between amphibians (Walther et al. 2002). We assessed the impact of climate change on 9 species of amphibians currently occurring in or just south of the Barents Region (also see Table 2a in the Appendix.). These species were the agile frog (Rana dalmatina), common frog (Rana temporaria), European tree frog (Hyla arborea), moor frog (Rana arvalis), pool frog (Pelophylax lessonae), common toad (Bufo bufo), natterjack toad (Epidalea calamita), northern crested newt (Triturus cristatus), and the smooth newt (Lissotriton vulgaris). Of these, the agile frog, the European tree frog, the pool frog, and the natterjack toad are currently not established in the Barents Region. However, part of the region is predicted to be suitable for the pool frog in future (Figure 7). If this species is able to disperse we may be able to find it in the region in future.

Figure 7. The current and future predicted potential distribution of the common toad

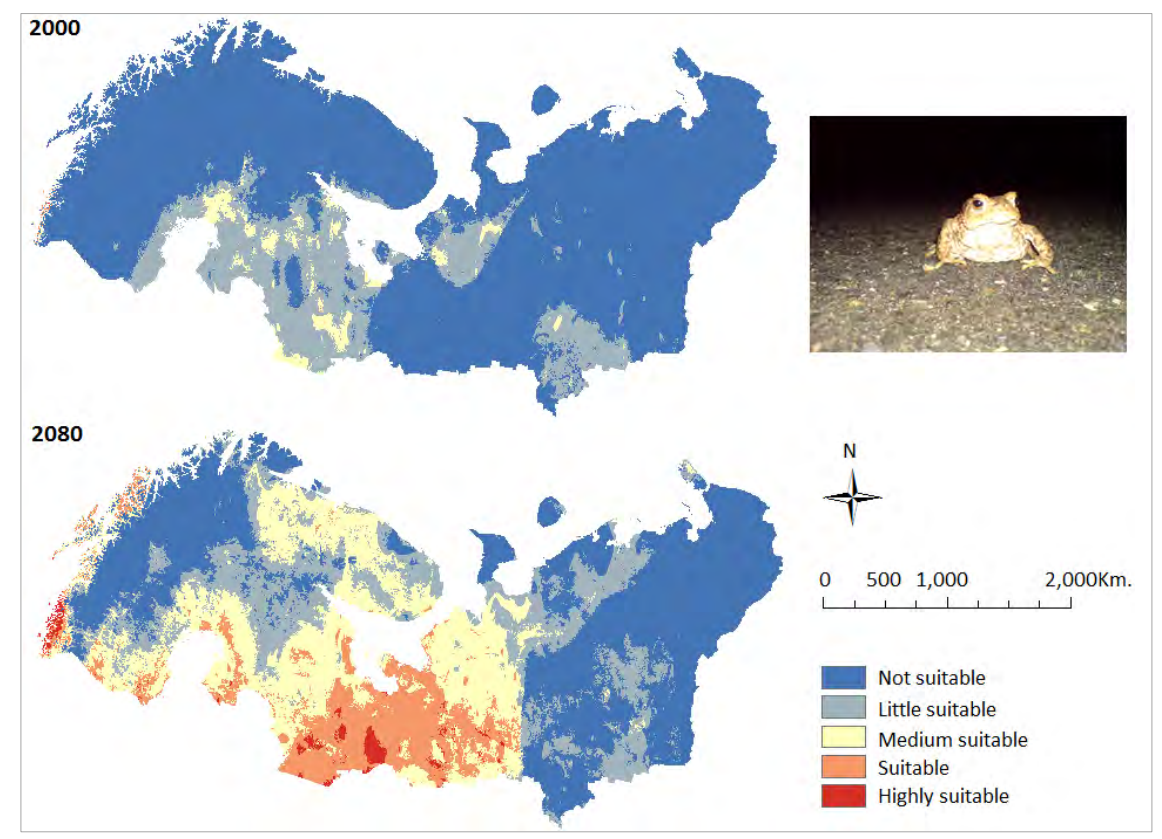


The other three species are unlikely to be able to occur in the Barents Region in future since none of the area was predicted to be suitable for these species to occur. The common frog, moor frog, common toad, northern crested newt, and the smooth newt are already present in the Barents Region and the models predicted that these species may be able to expand their range northwards in future. Although the models predict that the Barents Region may be increasingly suitable for a number of amphibians to occur, there may be several large hurdles for the species to overcome before they indeed occur in the region. Not only do they need to be able to disperse, there may be other problems as well. In the past few decades numerous populations of amphibian populations have suffered widespread declines and extinctions (Houlahan et al. 2000). Populations in Western Europe, the United Kingdom and North America for instance all showed declines (Houlahan et al. 2000). Also high-altitude populations in the Sierra Nevada in the United States have experienced strong declines for reasons largely unknown (Drost and Fellers 1996). Direct and indirect impacts of climate change have been suggested as reasons for the decline of other amphibian populations (Pounds et al. 1999; Walther et al. 2002). Increased exposure to ultraviolet-B (UV-B) radiation and increased prevalence of disease have been mentioned to cause declines. These causes are presumably related to climate-induced reductions in water depth at oviposition sites. Lower water tables have increased the mortality of embryos to a large extent because they are more exposed to UV-B radiation and are therefore more vulnerable to infections by pathogens (Kiesecker et al. 2001). Furthermore, warmer temperatures in winter have already caused dramatic changes in the reproductive cycles of a number of amphibians in the United Kingdom, in newts particularly (Beebee 1995). Newts entered ponds noticeably earlier due to climate change. Frogs however did not show such a large response. This may have consequences for the embryos and larvae of frogs since they are increasingly at risk from predation by newts (Beebee 1995).

Based on the examples mentioned above we have to be very careful before we can conclude that the Barents Region will be more suitable for amphibians to occur. However, none of the five species currently already established in the Barents Region are presently red listed on the Swedish red list for threatened species (http://artfakta.se/). Since their geographic distributions all extend southwards of the Barents Region, we may assume that climatic conditions for them in the region will improve. Also, the possible threat posed by lower water tables in lakes is less likely to occur in the Barents Region in future since precipitation is predicted to increase in future (Also see Chapter 3). 


\section{Birds}

We assessed the vulnerability to climate change of over 200 birds that currently breed in or just south of the Barents Region (also see Table $2 \mathrm{~b}$ in the Appendix). We complemented traditional species distribution modelling with an extensive literature review on a large number of natural history traits that may be potential risk factors in a warming environment. A total of 175 species, the winners, were predicted to expand their breeding range in the Barents Region in future. A further 14 species currently not breeding in the study region were predicted to expand their breeding range in the future into the study region, the colonizers. The other 31 species were predicted to contract their breeding range, the losers. None of the losers was predicted to lose its entire range in the Barents Region. The snow bunting (Plectrophenax nivalis) and the dotterel (Charadrius morinellus) were predicted to lose proportionally the most of their breeding range. The Siberian tit (Poecile cinctus), the horned lark (Eremophila alpestris) and the ring ouzel (Turdus torquatus) were also predicted to lose large parts of their breeding range. Species like the European goldfinch (Carduelis carduelis), barnacle goose (Branta leucopsis), coot (Fulica atra), woodlark (Lullula arborea), and the marsh tit (Poecile palustris) have currently relatively small breeding ranges in the Barents Region but are predicted to be able to breed in large parts of the region in future. The species for which we predicted that they will become losers are often habitat specialists (Figure 8), often breeding in cold-climate areas. The order Charadriiformes (waders, gulls and oaks) was slightly overrepresented amongst the losers (Figure 9).

Figure 8. Proportion of habitat specialists among the winner bird species and the loser bird species

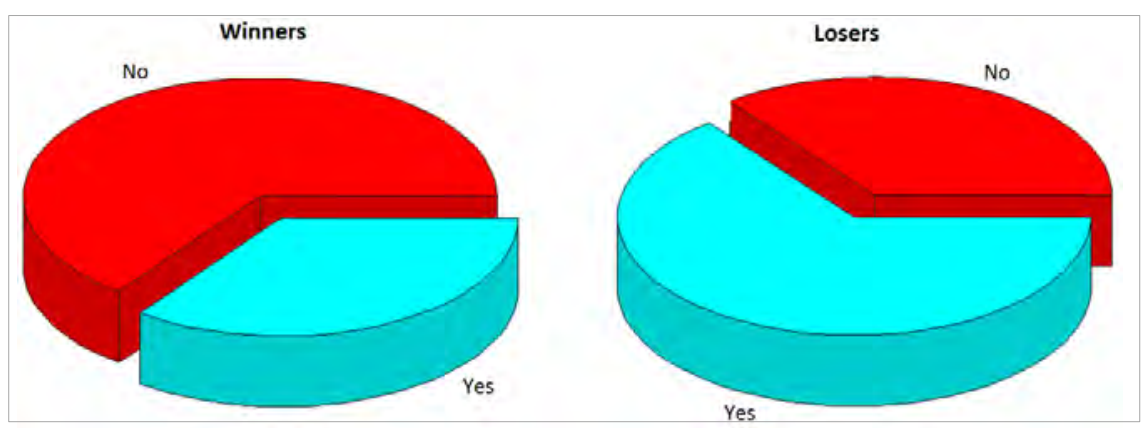


Figure 9. Representation of the orders amongst the winners and the losers

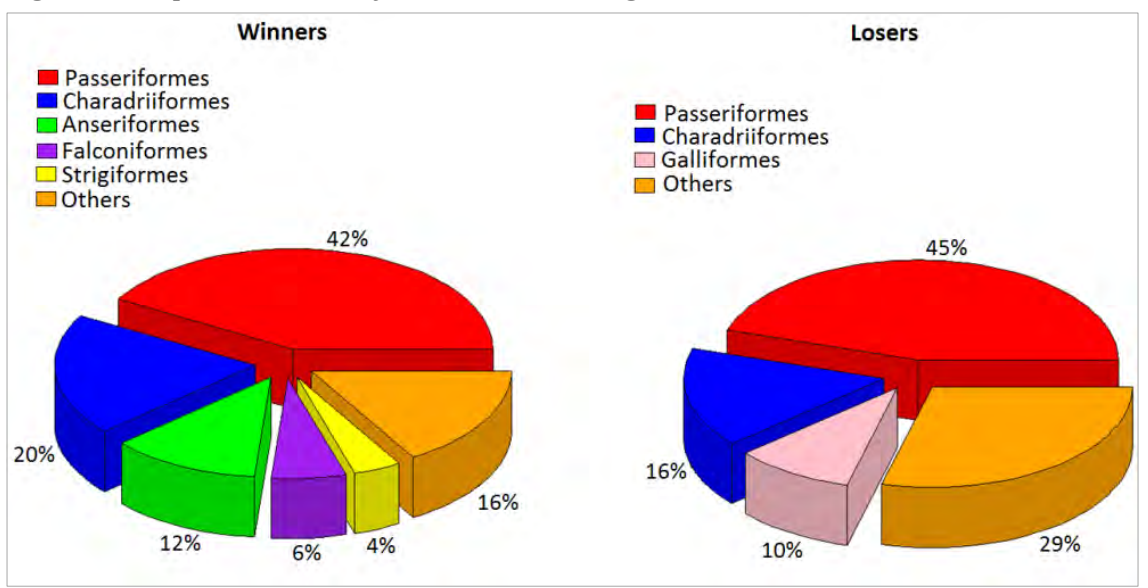

We further predicted that the species that are currently relatively widespread in the Barents Region will become losers and species from the south may take over (Figure 10). This will change existing species communities. We therefore face the prospect of range contractions and local extinctions amongst the cold-climate specialist species that currently breed in the Barents Region. In addition, we created a vulnerability index for birds breeding in the Barents Region based upon their vulnerability to future climate change and based upon their natural history traits (Figure 11). Traits that were included were amongst others: migrating, diet breadth, habitat specialism, ground nesting, average clutch size, number of incubation days, number of fledging days, the length of the breeding season, number of broods, adult and juvenile survival rates, age at first breeding, and typical lifespan. 
Figure 10. The mean percentage area of the Barents Region that is predicted to be suitable for breeding for colonizers (C) losers (L) and winners (W) in 2000 (Current), 2080 (Future) and the mean percentage that is predicted to remain suitable over the years (Stable). Error bars represent \pm 1 standard error, * signifies a significant difference at $\alpha=0.05(p<0.001)$

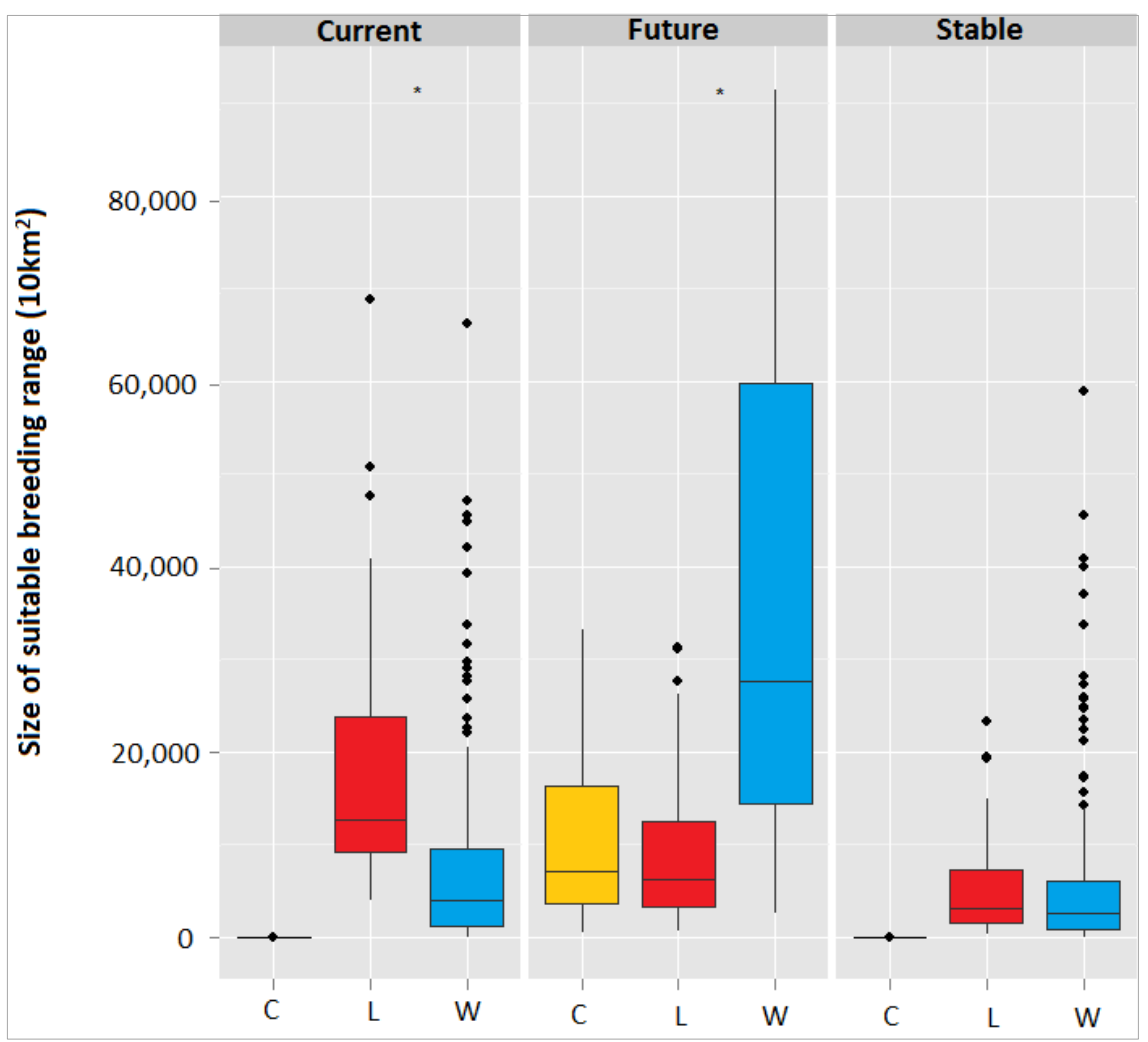

Figure 11. A vulnerability index for birds that breed in the Barents Region. Red dots represent loser birds, blue dots represent winner birds and black stars represent colonizers

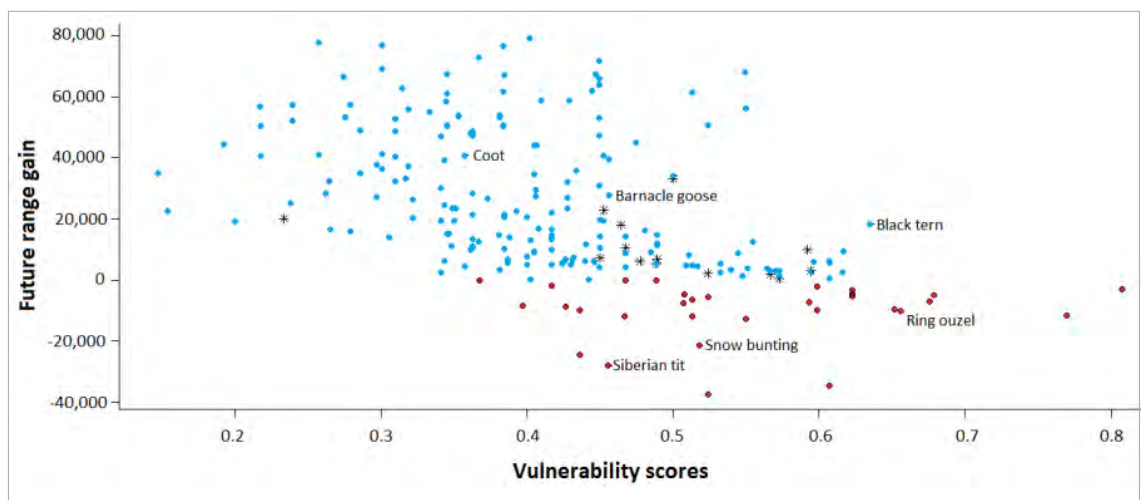


This index may help identify which species are likely to need additional conservation in future. A species like the black tern (Chlidonias niger) for instance is predicted to increase its breeding range in future due to climate change. However, it received a high vulnerability score because it has certain traits that may make the species vulnerable in general. This vulnerability may be enhanced by climate change. The species is a longdistance migrator and migratory species are likely to rely on different habitat types during their breeding season than at their wintering grounds (Elphick 2007), making it more vulnerable to climate change. Furthermore, the species depends on a specific biome (freshwater marshes) during the breeding season. This also does not increase its chances of persistence because of the threats these ecosystems face themselves due to likely increased shore erosion (Brown and McLachlan 2002), and because of the vulnerability of shorebirds to newly established predators like the American mink (Neovison vison) (Nordström et al. 2003), especially in combination with ground nesting strategies. On top of the effects future climate change may have on species, traits like those mentioned above should be taken into account when designing conservation strategies.

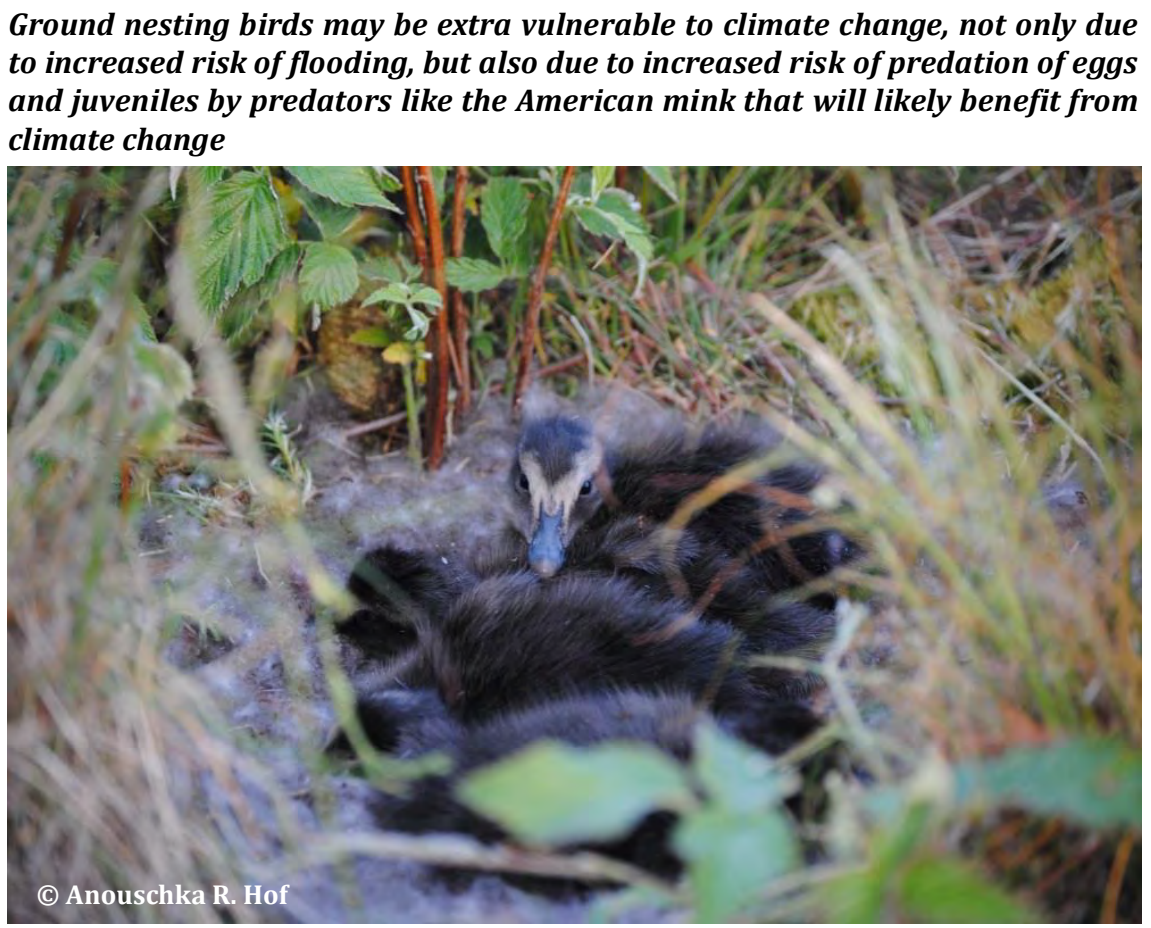




\subsection{The black guillemot}

The black guillemot (Cepphus grylle) is a seabird dependent on both terrestrial and marine habitats, which makes it particularly susceptible to climate change (Sydeman et al. 2012). The species is listed as vulnerable on the HELCOM red list, the red list of Baltic Sea species (Baltic Marine Environment Protection Commission - Helsinki Commission). The IUCN red list mentions future climate change and extreme weather events as threats to the global population, since they may cause shifts in their niche and alterations in habitat. The species is on the southern limit of is range in the Baltic Sea region, making it likely that climate change may affect the black guillemot population in this region (Daunt and Mitchell 2013). Native and non-native mammalian predators, like the American mink, may also be a major threat to black guillemots (Jakt \& Jägare 2005). Climate change is predicted to positively affect the American mink in the Barents Region (Hof et al. 2012b), which may pose additional threats to the species. We assessed the impact of future climate change on the breeding and foraging sites of the black guillemot in the Baltic Sea.

The black guillemot, a seabird that is already vulnerable in the Baltic Sea and that will likely be negatively affected by future climate change

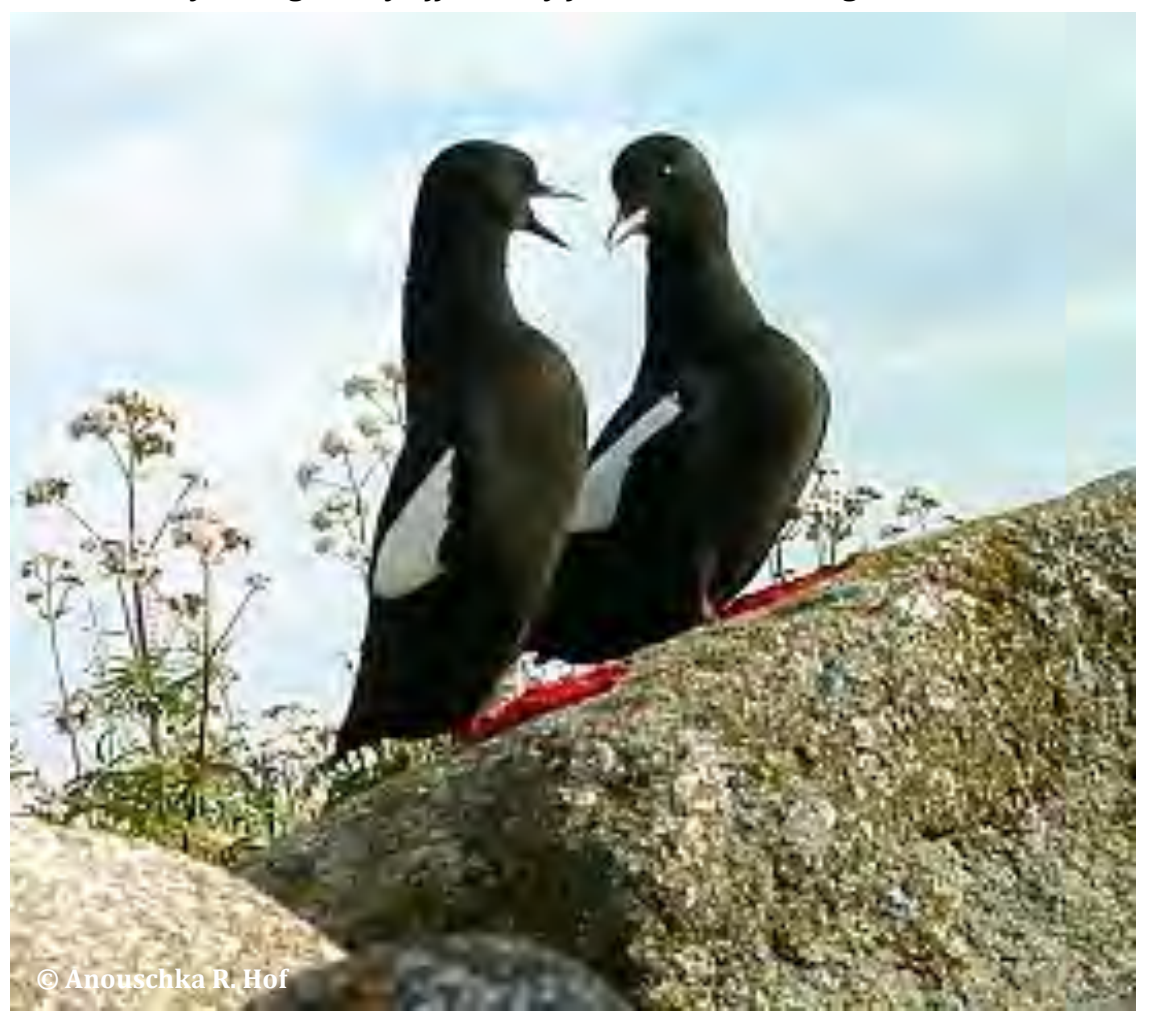


Our results suggest a severe decrease in suitable breeding areas. Up to $94 \%$ of the area that is currently suitable may be lost by 2070 . The northern part of the Gulf of Bothnia will mainly remain suitable for breeding by then. We further predict that only the northern part of the Gulf of Bothnia remains suitable for foraging during the breeding season (Figure 12). However, new foraging sites may appear in the south of the Baltic Sea, assuming that increased productivity relates to suitable foraging sites. Nevertheless, we think it unlikely that this area will indeed be suitable for black guillemot to occur in future due to the lack of climatic conditions suitable for breeding. We therefore expect that only the northern part of the Baltic Sea region, the Gulf of Bothnia, will remain to be suitable in future both as a breeding ground and for foraging during the breeding season. This scenario is very alarming on a sub-species level for Cepphus grylle arcticus; this population currently breeds in the Danish Kattegat and in the Swedish west coast area, where it may not be suitable for breeding in future if the species does not adapt. Our predictions give an indication where threats may be most severe and could therefore be used as guidance in conservation planning. The results suggest that the climatic conditions at breeding sites will be the limitating factor for its geographic distribution and not the climatic conditions at the feeding site. We stress that conservation measures during the breeding season should integrate potential future threats and focus on breeding sites across the current and also across the future potential geographic ranges of seabirds like the black guillemot.

Figure 12. The predicted shift in the global breeding range of the black guillemot under the 6.0 RCP for 2070

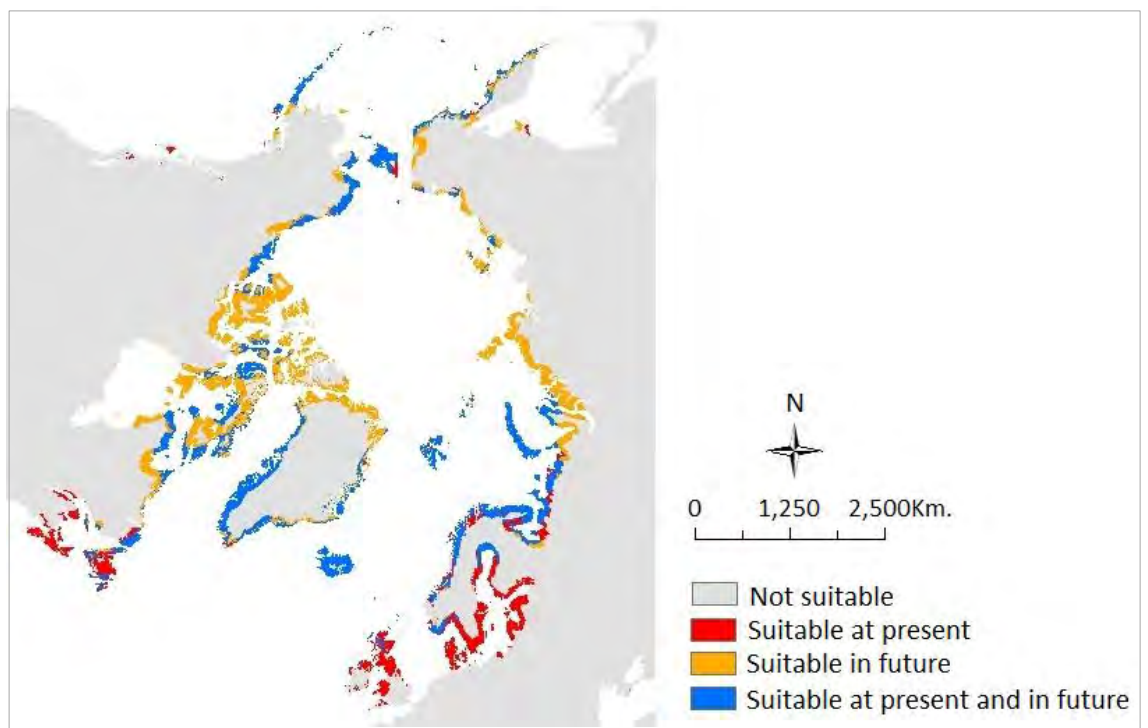




\subsection{The golden eagle}

While trying to reduce greenhouse gas emissions, many countries are investing in renewable energy sources like wind power (Fielding et al. 2006). Sweden has for instance the goal to attain $49 \%$ of renewable energy by 2020 and the country has high potential for wind power (http://energimyndigheten.se). Therefore, the number of wind farms has increased quickly recently (http://www.lansstyrelsen.se). This increasing number of wind farms raises concerns, since they may have harmful impacts on species like the European golden eagle (Aquila chrysaetos chrysaetos) (Fielding et al. 2006; Moss 2011; Walker et al. 2005). This species is already classified as near threatened in Sweden according to the criteria's set by the International Union for the Conservation of Nature (http://www.artfakta.se). Many birds of prey, and especially golden eagles, have already died through wind turbine blade collisions (Fielding et al. 2006; Orloff and Flannery 1992). While planning for future wind power development it is very important to consider future predictions of species distributions, especially for birds, as they have a high dispersal capacity and seem to react rapidly to climate change (Bellard et al. 2012). In order to investigate possibilities to develop wind power in the best conservation manner, the potential current and future distributions of the golden eagle in Sweden were studied.

The Swedish population of the golden eagle is estimated to hold approximately 1,200 to 1,400 reproductive individuals and seems to be stable or growing (Moss 2011). However, a sudden increase in mortality has recently been detected, which is believed to be caused by train collisions, persecution and wind turbines (Moss 2011). The low reproductive rate of the golden eagle makes the species vulnerable to adult mortality (Hunt 2002). In fact, as top predators their population abundance is low (Whitfield et al. 2001). The Swedish population is mainly distributed across mountainous and boreal regions in the north $\left(61-69^{\circ} \mathrm{N}\right)$ with some small areas in the south (Moss 2011). Golden eagles generally migrate a lot the first three or four years after which they return to their nesting area to establish their territory (Systad et al. 2007). In Sweden they sometimes nest at cliff edges but more often in old trees, with a large preference for pine over spruce (Tjernberg 1983). They exploit the area close to their nest more often than the other parts of their territory (McLeod et al. 2002). Golden eagles generally avoid human disturbance (López-López et al. 2007) and prefer mixed habitat with forests for nesting and open lands for hunting (Moss 2011). They have a rather broad food niche (Nyström et al. 2006), which permits them to adapt their diet 
to prey availability (Steenhof and Kochert 1988) and allows them to stay in the same territory year after year (Steenhof et al. 1997). Nonetheless, they still favour some prey species over others (Steenhof and Kochert 1988); in Sweden the main prey species are mountain hare (Lepus timi$d u s$ ) and Tetraonid species, except for Gotland where they mainly feed on rabbits (Oryctolagus cuniculus) and hedgehogs (Erinaceus europaeus) (Tjernberg 1981). The breeding success of the golden eagle appears to be closely linked to the availability of these prey species (Nyström et al. 2006) and the presence of these species has therefore been accounted for in the modelling.

According to the model predictions, the golden eagle may be able to benefit from future climate change in Sweden as the amount of area that climatologically and habitat wise is suitable for its needs is increasing (Figure 13). Sweden is one of the northernmost areas within the global golden eagle distribution (http://www.iucnredlist.org), so the increased suitability following future climate change is not unexpected as northward movement is the common trend (Parmesan et al. 1999; Hickling et al. 2006). According to the model, the potential distribution of the golden eagle may change to a large extent from the present till 2080. According to the climate scenario and the limited number of biotic factors used in this study, Sweden will be more suitable for the golden eagle to occur than at present, which might offer positive prospects for the species. However, the predictions of suitability should not be viewed at the grid cell-level but rather at the landscape level. Furthermore, the results are predictions; it is not necessarily so that the species will indeed be more widespread and abundant in future as is predicted, since there are other factors influencing its abundance as well. Indeed, the predictions only depict areas that are potentially suitable according to the variables entered in the model, this does not automatically mean that a pair of golden eagles will indeed move to potentially highly suitable areas in future, but merely states that this area is suitable according to the climatic scenario and the factors included in the model. The nest site availability for example is not included in the predictions and will obviously influence the possible occupation of a specific area by golden eagles (Tjernberg 1983). The potential range expansion of golden eagles calls for protection of potential nesting trees in areas where it is absent today. 
Figure 13. The current and future predicted potential suitable areas for the golden eagle

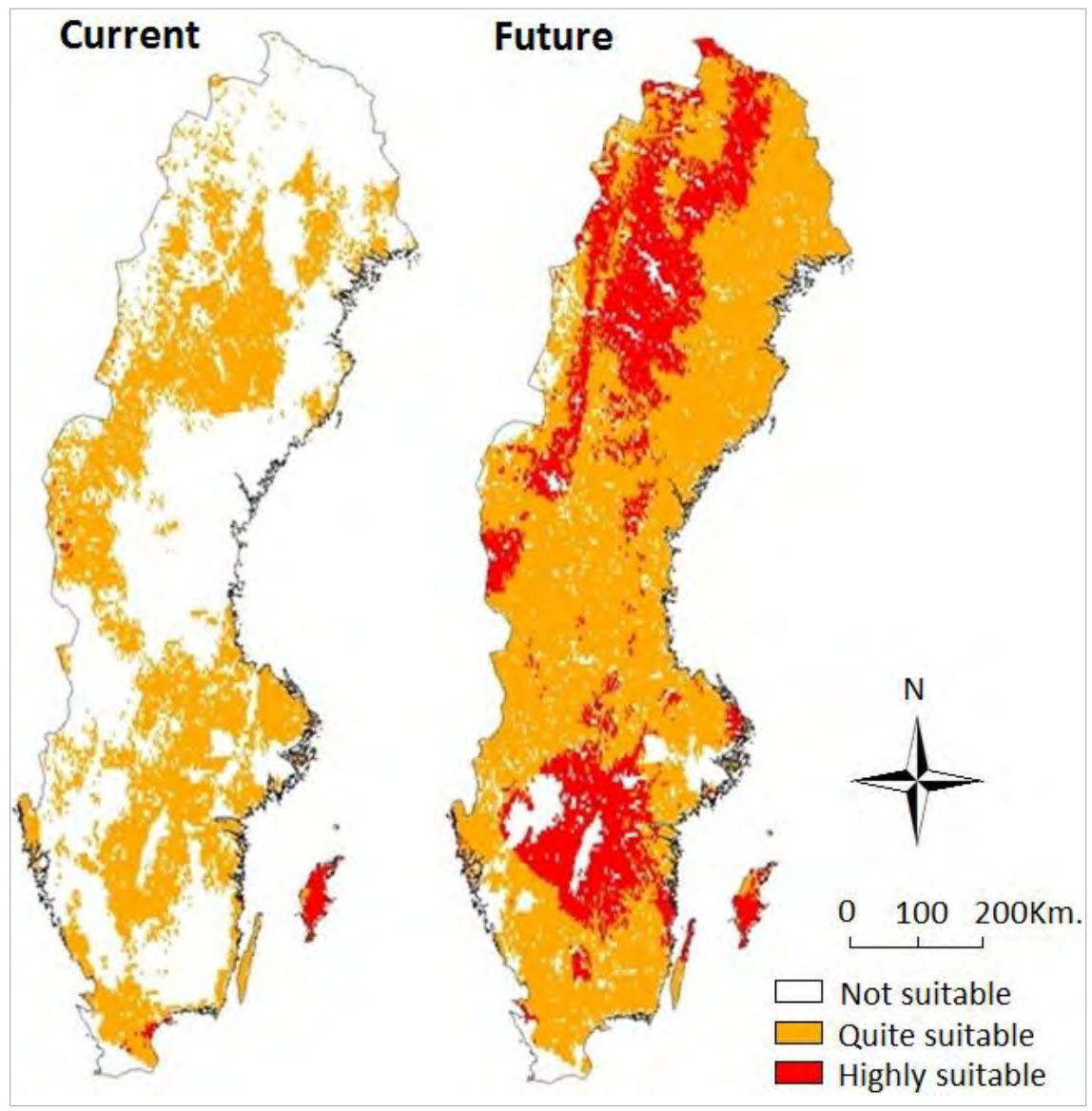

The best location for wind farms is dependent on many factors, such as wind supply, aviation, landscape visual concern, and ecology (Madders and Whitfield 2006). Wind farms tend to be situated at locations with strong winds and away from human population (Madders and Whitfield 2006). However golden eagles favour the same places (Moss 2011), which leads to some conservation issues (Madders and Whitfield 2006), especially since the golden eagle is classified as near threatened in Sweden (http://www.artfakta.se). In order to conserve the species, areas that need extra protection must be identified (Araújo et al. 2011). Besides, the potential future distribution of golden eagles is much larger than the current one and so it is essential to take these new predictions into account for wind power management.

The areas where the wind speed is low and the suitability for eagles is potentially high, such as central southern Sweden and western northern Sweden, are the worst locations for future wind farms (Figure 14). The 
areas where it is potentially quite suitable for golden eagles and that have low wind speeds should ideally be avoided for wind farm construction as well; especially the areas which are potentially suitable both now and in future. Instead, the regions where wind speeds are high and the potential suitability for golden eagles is low could better be prioritized for establishing the new wind farms (Figure 15). It is however important to highlight that the model is not accurate enough to predict the best locations for future wind farms exactly and that the maps and calculations cannot be directly used for choosing locations of future wind farms. Instead, the maps and calculations show that areas suitable for golden eagles may change between now and the future and that some areas seem to be better for wind farms while trying to limit their impact on golden eagles at a landscape scale. The death rate of birds through wind power structures is highly site specific (Barclay et al. 2007; Illner 2011) which highlights the need of species distribution predictions, to minimize impacts. However, other parameters can influence the collision rate and should also be considered before building a new wind farm, such as which types of wind turbines to use (Barclay et al. 2007; Hunt 2002). 
Figure 14. Area that is potentially quite suitable or highly suitable for the golden eagle (currently, in the future and in both time periods) and that has low wind speeds

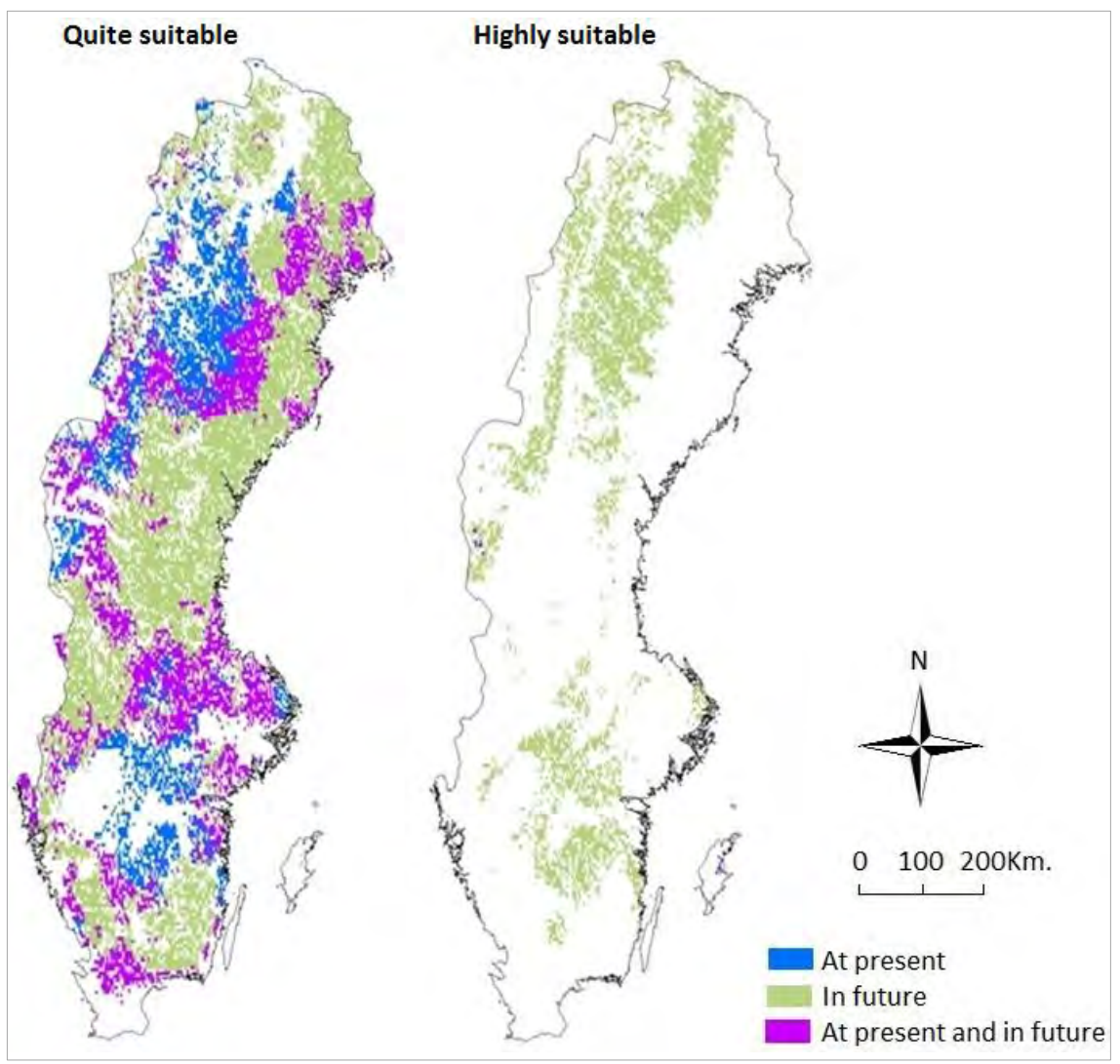


Figure 15. The area most suitable for wind farms, i.e. areas that are potentially not suitable for the golden eagle (currently, in the future and in both periods) but do have high wind speeds

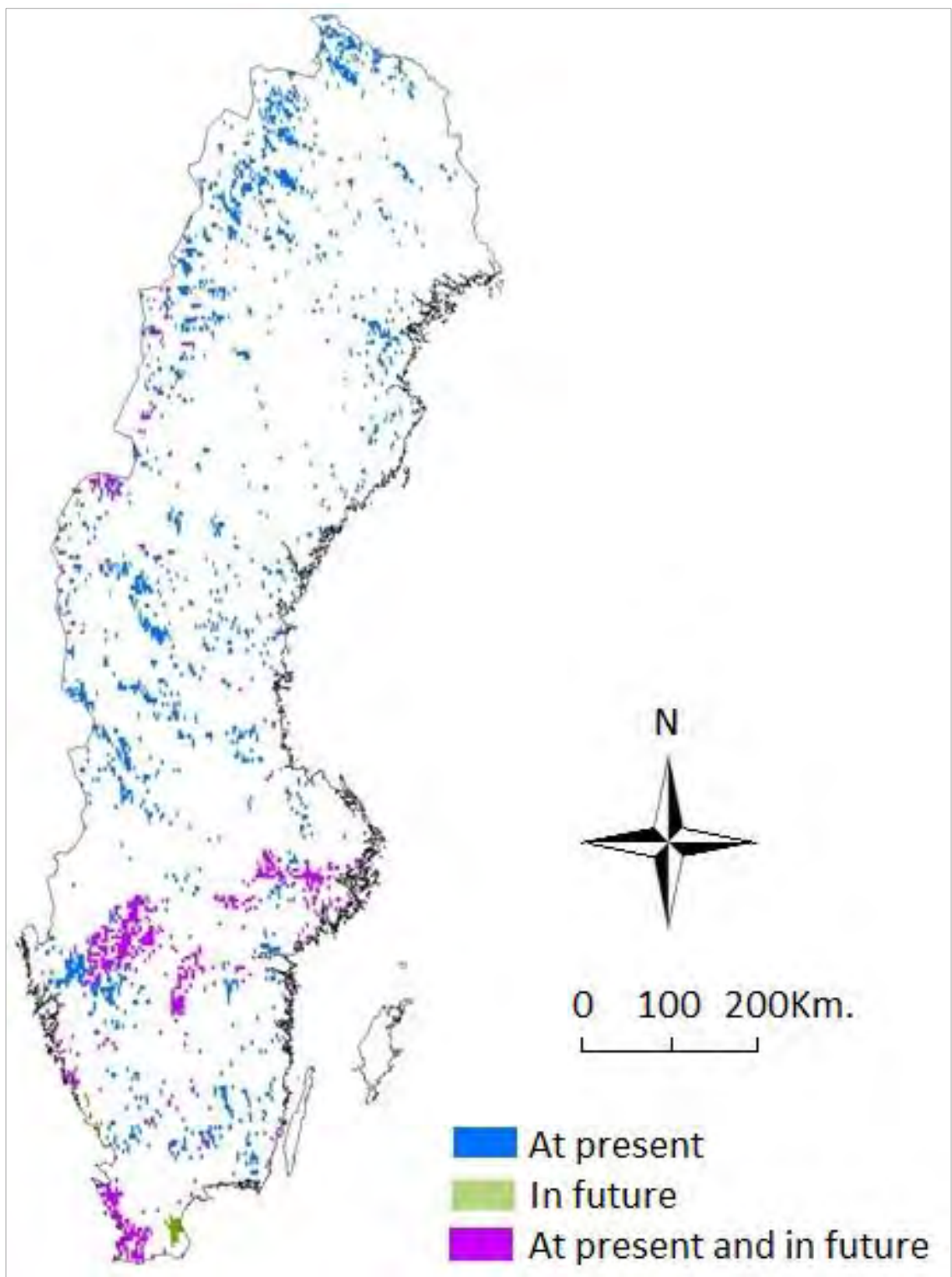




\subsection{The spotted nutcracker}

Climate change may alter the geographic distribution of many species, which may result in species colonizing new regions and potentially becoming invasive when they encounter new, more preferable, climatic conditions. Invasive alien species have been one of the major causes of species' extinctions in the past. Together with habitat loss and fragmentation they drive present-day species' extinctions (Hoffmann et al. 2010). Climate-driven invasions of species may transform ecosystems to such a degree that alien species become dominant and the diversity of native species decreases (Mack et al. 2000; Gritti et al. 2006). To preserve native biodiversity it is therefore highly desirable to get a better understanding of how potentially invasive species will respond to climate change. As a focus study we therefore quantified to which extent the spread of the alien and potentially invasive stone pine species, the Siberian pine (Pinus sibiri$\mathrm{ca}$ ) and the Swiss pine (Pinus cembra), in Sweden in a warming climate is augmented by its dispersal agent: the slender-billed nutcracker (Nucifraga caryocatactes macrorhynchos), alien to Sweden.

Climate change may benefit the spotted nutcracker (Nucifraga caryocatactes sp.) in northern Europe (Archaux 2004; Brommer 2004). One of the two subspecies of the spotted nutcracker present in Sweden, the slender-billed nutcracker, is not native to the country and specializes on seeds from stone pines (The, Berggren 2005; Tjernberg 2010). These pines are not native to the Barents Region and potentially invasive according to the European Network on Invasive Alien Species (http://www.nobanis.org/). Stone pines rely on birds, and especially on the nutcracker, for the dispersal of their seeds (Tomback and Linhart 1990; Mattes 1994). Since the survival of stone pine seedlings is largely limited by long lasting snow cover in spring in the Alps (Senn et al. 1994; Didier 2001), the northern regeneration limit of stone pines in the Barents Region will likely shift northwards in future with climate change. 
The slender-billed spotted nutcracker; recently established in Sweden and the main dispersal agent of the alien and potentially invasive Siberian pine and Swiss pine.

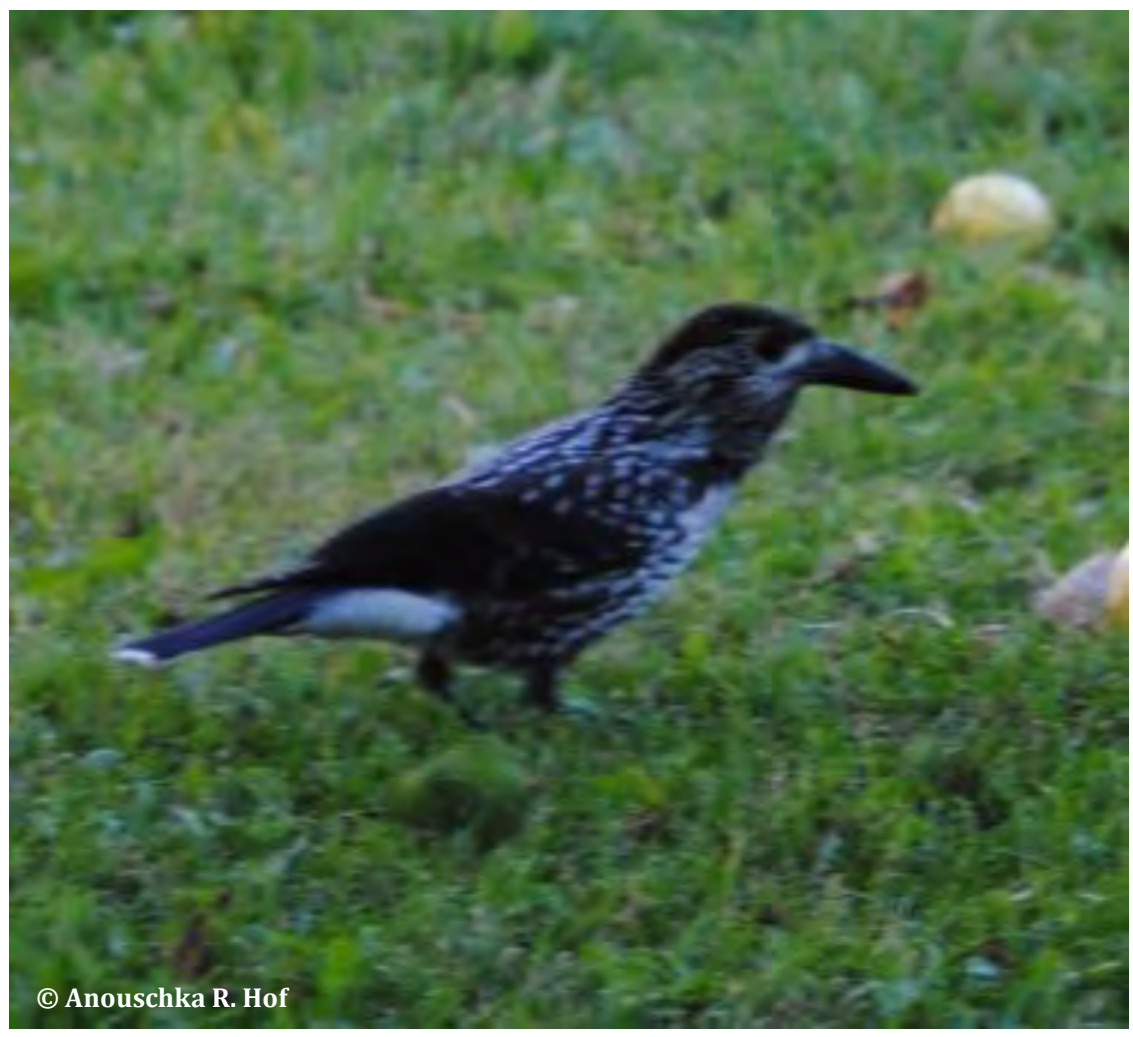

We found that the predicted presence of the slender-billed nutcracker significantly augmented the increase of the predicted future range of the stone pines under climate change. Both the slender-billed nutcracker and the stone pines may significantly increase their range in future (Figure 16). This result stresses the need for nature conservationists and managers to incorporate species interactions and climate change when designing appropriate plans with regard to invasive species. Although the implications of the predicted future spread of the slender-billed nutcracker might be limited, since the very similar thick-billed nutcracker (N. c. caryocatactes) is native to Sweden, the effects of the stone pines should not be neglected. They are currently classified as potentially invasive in parts of the Nordic region (http://www.nobanis.org/). 
Figure 16. The average predicted current, future and stable geographic range of the slender-billed nutcracker and the stone pines under RCP 4.5

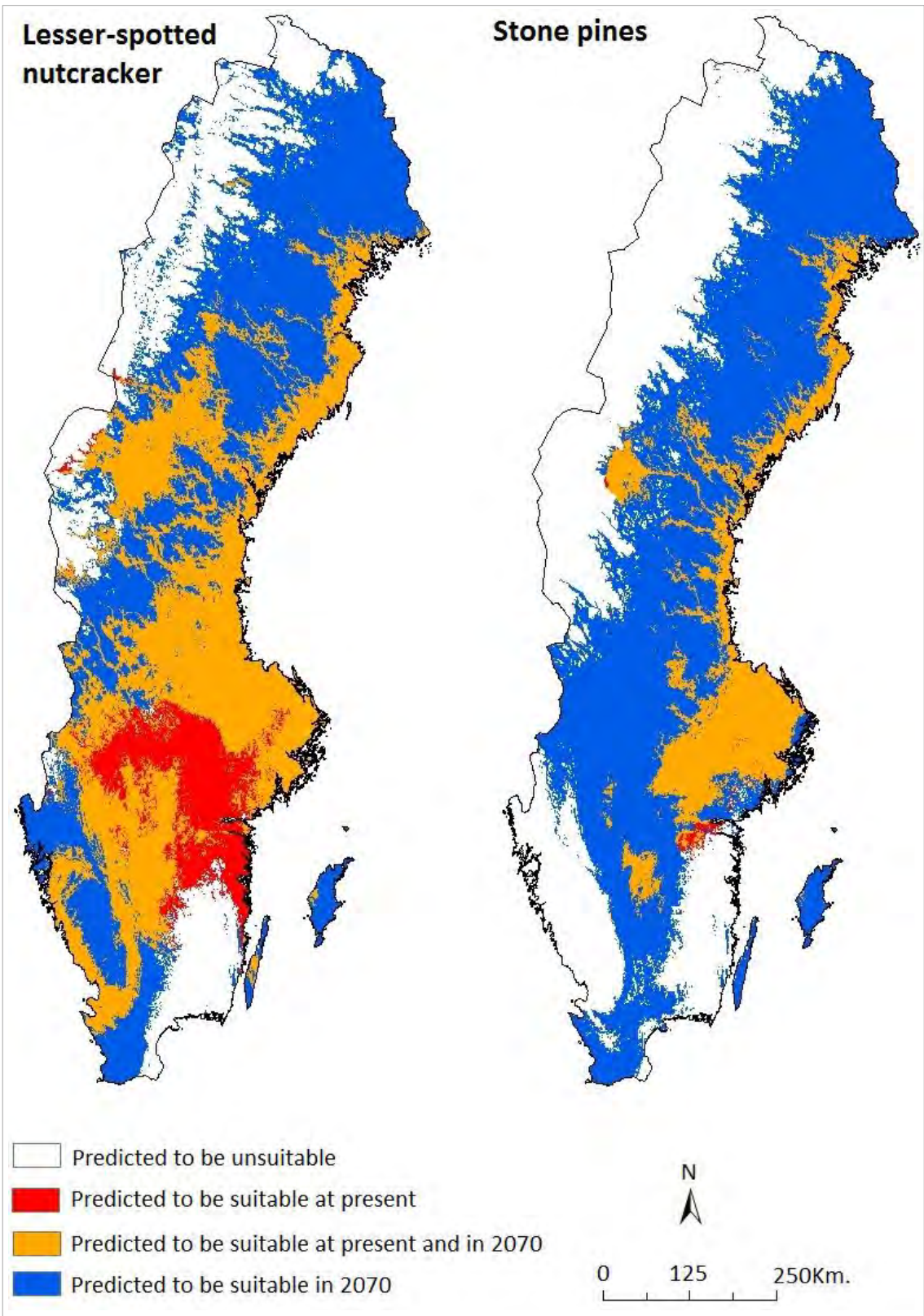





\section{Gastropods}

Especially ectothermic species, such as terrestrial gastropods, may be affected considerably by alterations in temperature and precipitation regimes (Aragón et al. 2010; Deutsch et al. 2008). In addition to these direct impacts, climate change can have a large impact on species communities and habitat structure. Since terrestrial gastropods are also sensitive to alterations in habitat structure and species interactions, it is expected that a continued climate change will affect terrestrial gastropods in ways not easy to anticipate. We assessed the current and future geographic distribution and diversity of 99 terrestrial gastropod species from the order Stylommatophora throughout Europe. We found that most species will be able to expand their geographic distribution range northwards (Figure 17). Only 14 species were expected to contract their future distribution range. Most of these were slugs, which is to be expected since slugs are not protected against unfavourable environmental conditions by a shell, like snails are. Their activity is thus to a larger extent dependent on microclimatic conditions (Crawford-Sidebotham 1972).

Considering the predicted increase in the geographic range of the majority of the gastropod species assessed, it is to be expected that their diversity in the Barents Region will increase. However, terrestrial gastropods, such as the Stylommatophora, are slow moving species. Terrestrial snails are for instance only able to disperse up to a few meters per year in environmentally hospitable conditions (Baur 1988; Welter-Schultes 1998). Active dispersal of terrestrial snails over large distance therefore does not generally occur (Hausdorf 2000). It is thus questionable whether species will be able to reach their full potential extent of occurrence in future. Nevertheless, species are able to colonize large areas by means of passive and aerial dispersal (Hausdorf 2000; Vagvolgyi 1975). Range shifts of terrestrial gastropods will alter species diversity and abundance, which can have far reaching consequences for agricultural management as they can damage crops. In addition, predators of macro-invertebrate prey might be affected by changes in terrestrial gastropod abundances. This needs to be taken into account in conservation planning. 
Figure 17. Mean range contraction/ expansion in Europe of losers and winners amongst slugs and snails, * denotes a significant difference

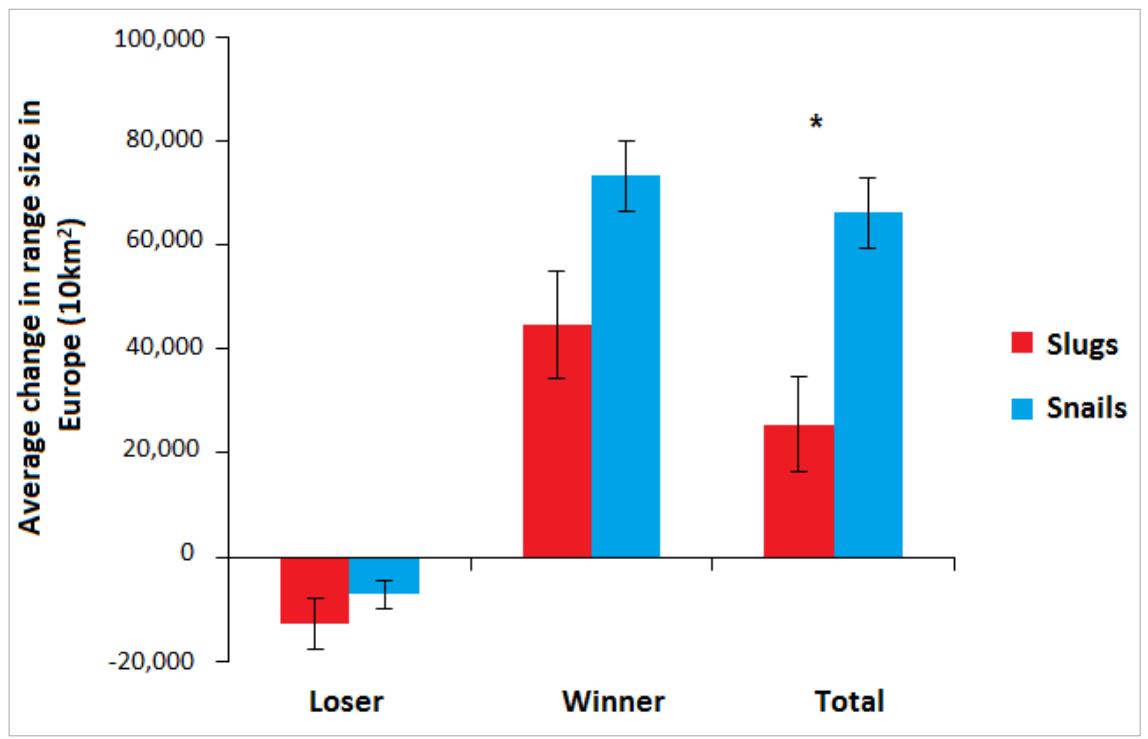

Pearson $\chi^{2}=8.086, d f=1, p=0.040$ 


\section{Insects}

One of the first reported incidences of climate-change induced poleward shifts of the geographic distributions of a relatively large number of species was the study by Parmesan et al. (1999). This study reported that 22 of 35 non-migratory European butterflies had shifted their ranges northwards by $35-240 \mathrm{~km}$ in the last century, whilst only one shifted to the south. We assessed the future potential geographic distribution of 84 insect species of the order Lepidoptera, which includes both butterflies and moths, in the Barents Region (also see Table 2c in the Appendix). Of the 84 species assessed, 28 were not yet established in the Barents Region. For three of these species, Coenonympha arcania, Coenonympha pamphilus, and Maniola jurtina, there will still not be suitable climatic conditions in the Barents Region in future. However, conditions are predicted to be suitable by 2070 for the remaining 25 species.

The Comma (Polygonia c-album), one of the species predicted to become more widespread in the Barents Region in future

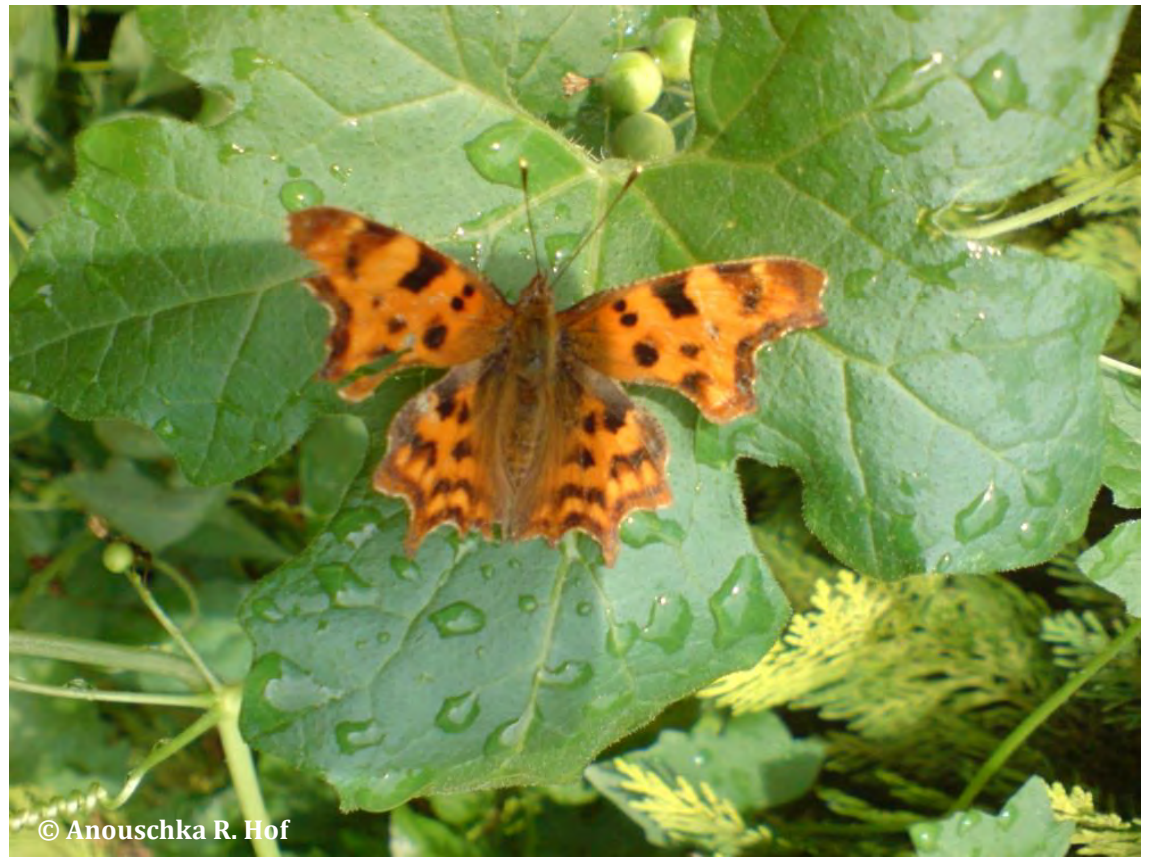


In total 17 species were predicted to lose part of their range, and the region will environmentally no longer be suitable for five of these: the dingy fritillary (Boloria improba), the mountain fritillary, (Boloria napaea), the pale arctic clouded yellow (Colias werdandi), the scarce heath (Coenonympha hero), and the Alpine grizzled skipper (Pyrgus andromedae). Four of these species can generally only be found in cold-climate areas. It is therefore not surprising that these species will lose part of their range with a warming climate. One of them, the dingy fritillary, is currently classified as Vulnerable by the Swedish red-list for species (Eliasson 2012). The fifth species, the scarce heath that is currently classified as Near Threatened, is associated with grassland, habitat that is predicted to be less common in future (Berglind 2007). The remaining 38 species were predicted to be able to expand their range with climate change.

Figure 18. Boxplot of the percentage of the Barents Region covered by the geographic distributions of losers, species that were predicted to lose part of their range in future, and of winners, species that were predicted to gain more range in future, at present and in 2070 according to the 4.5 Representative Concentration Pathway of the downscaled general circulation model HadGEM2-ES

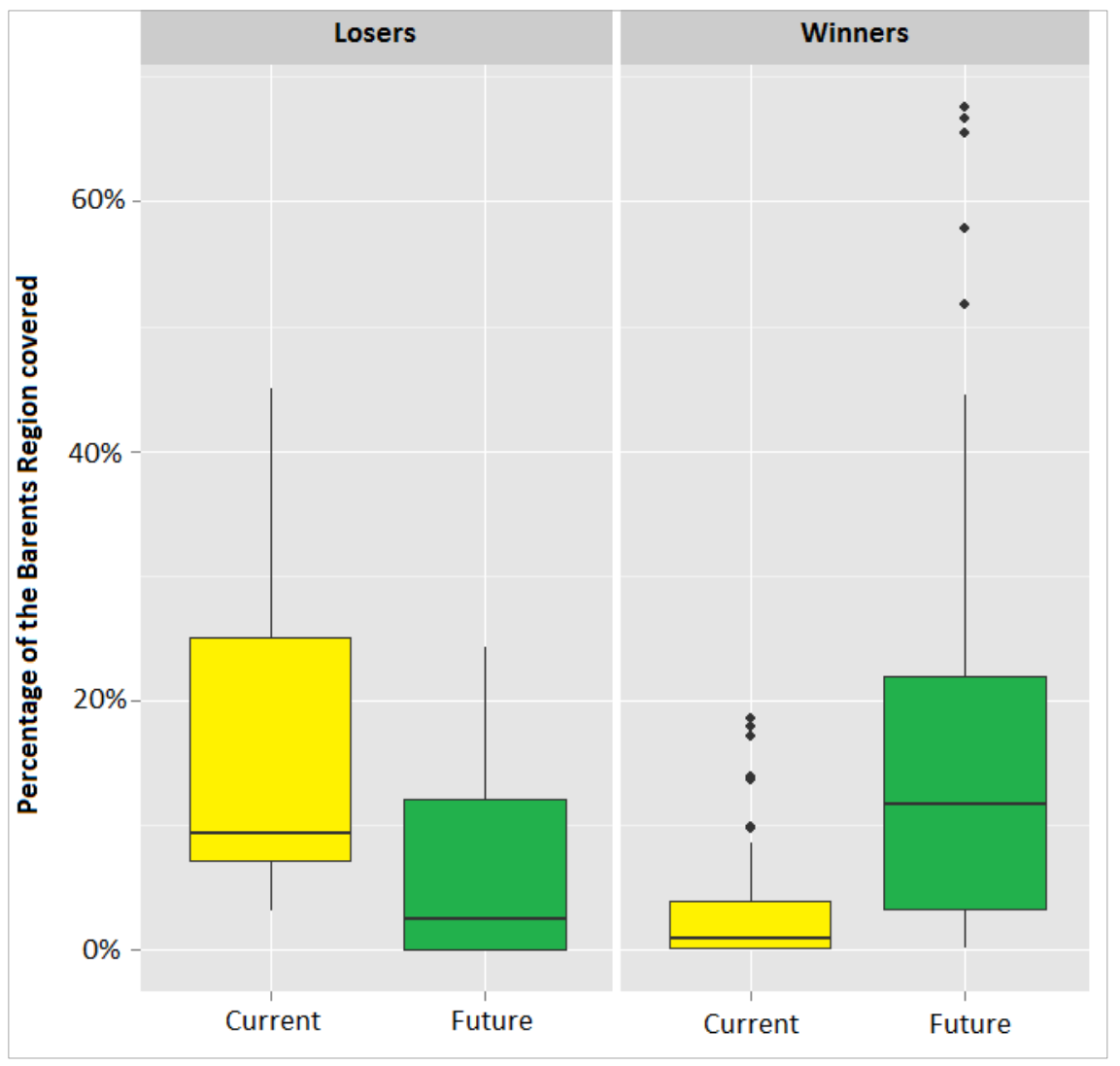




\subsection{Possible pest species in the Swedish boreal forest}

Insects can have large effects on forest ecosystems. With the expected rising temperatures, outbreaks of insect pests may be more frequent (Jönsson et al. 2009; Schlyter et al. 2006). This can have large consequences for forest ecosystems and may negatively affect the forestry sector (Soja et al. 2007). In order to be better able to predict where, but not if, outbreaks may occur in future we investigated the potential future (2070) geographical distribution of thirty prospective insect pest species from the order Coleoptera and Lepidoptera in Swedish boreal forests. We also assessed the geographical extent to which boreal needle leaved forests in Sweden may be affected. We found that for most species the environmental conditions will likely improve in large parts of boreal Sweden in future. Assuming that species will be able to disperse, most species may experience large increases in their potential distribution in future. This may result in outbreaks in "new" areas. It is therefore likely that more trees will be infested by pests in future, which may have large implications for the Swedish forestry sector.

To give an example, one of the species assessed was the European spruce bark beetle (Ips typographus); one of the most damaging pest species in Europe (Christiansen and Bakke 1988). The European spruce bark beetle can cause substantial damage to spruce stands and is able to rapidly become very abundant (Wermelinger 2004). Weakened spruce stands are particularly susceptible to outbreaks of this species (Wermelinger 2004), but rarely occur in the Barents Region today (Eidmann 1992; Eriksson et al. 2005). This is because current climatic conditions only allow the species to reproduce once a year (Sauvard 2004). However, outbreaks of the European spruce bark beetle are thought to be increasingly common in the Barents Region in future because of changing climatic conditions that allow the species to reproduce more often (Jönsson et al. 2009; Öhrn 2012). Our results suggest that the European spruce bark beetle will also likely expand its geographic range extensively (Figure 19 and Figure 20), which may make spruce stands in the Barents Region more likely to be infected by this species in future than at present. 
Figure 19. The predicted current extent of boreal needle leaved forest in Sweden affected by the European spruce bark beetle

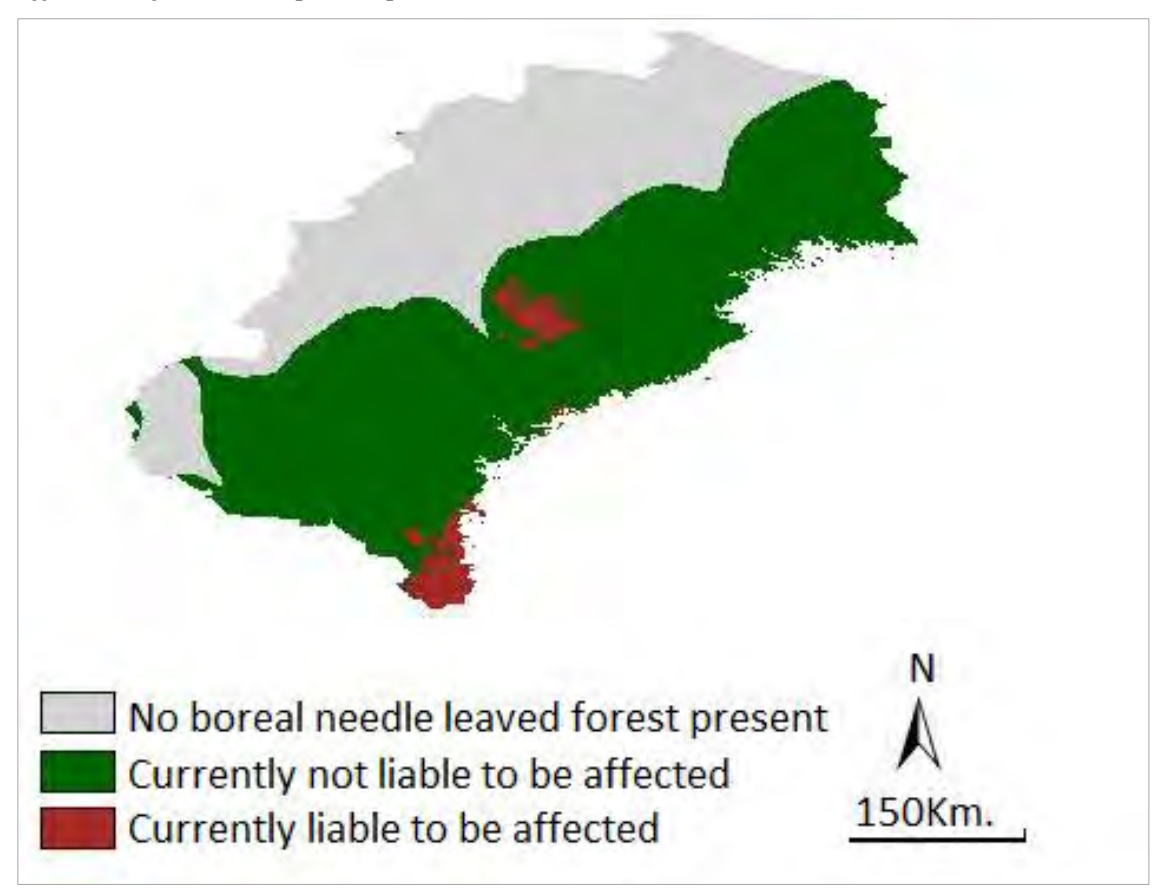

Figure 20. The potential extent of boreal needle leaved forest in Sweden to be affected by the European spruce bark beetle in future
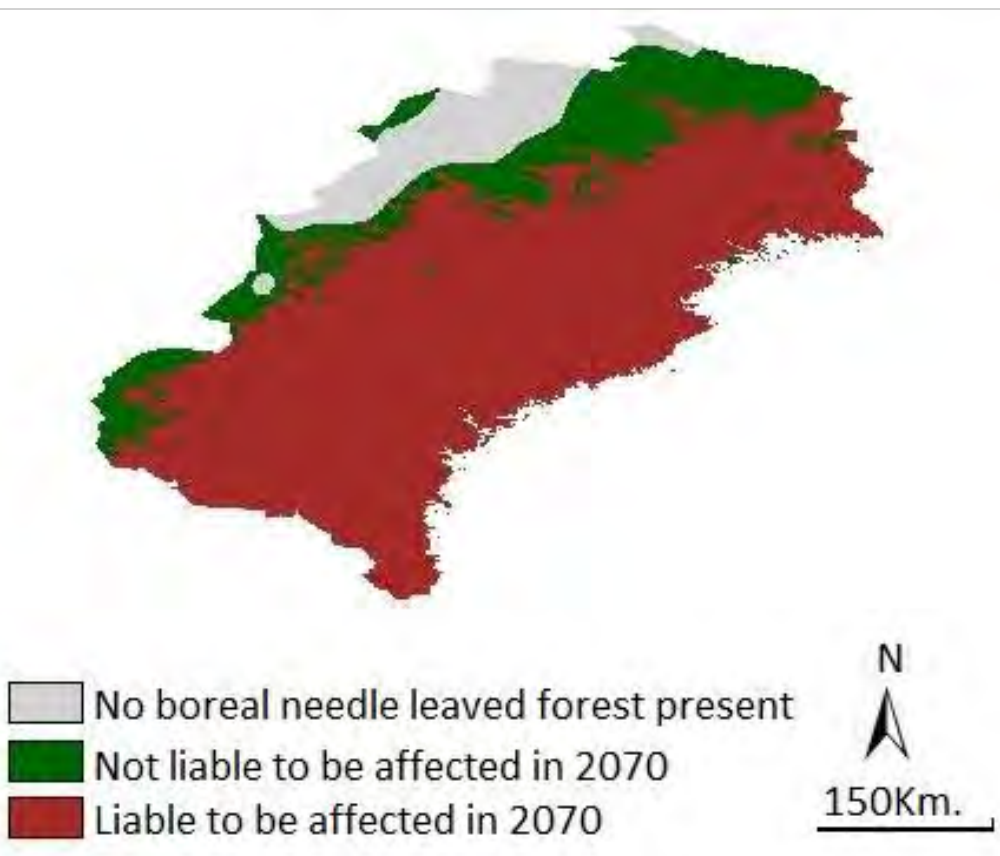


\section{Mammals}

We assessed potential changes in the geographic distribution of all terrestrial mammal species currently present in the Barents Region along with species that might colonize. Our results indicate that 43 out of the 61 species modelled will expand and shift their ranges, mostly in a northeasterly direction, in future. This is based on the assumption that species are able to colonize all areas that become climatically suitable. We further predict that the climate in the Barents Region will become suitable to ten more mammalian species, of which eight bats. Mammalian species richness in the Barents Region is therefore likely to increase substantially when full dispersal ability is assumed (Figure 21). However, when we assumed that species will not be able to disperse beyond areas that are currently suitable for them, we found that the vast majority of species will likely lose part of their geographic range, but none is predicted to go extinct. We can thus conclude that the climate in the Barents Region will in future be more suitable in large parts of the Barents Region than at present for most of the mammals currently present (Figure 22). Warmer and wetter conditions favour more species. However, changes in the landscape and in ecosystem management caused by socioeconomic activities can impact the distribution and dispersal ability of species to a large extent. It is therefore uncertain if species will be able to reach areas that will be suitable for them in future. Species like the hazel dormouse are slow dispersers and highly dependent on continuous habitat in order to migrate into new areas (Bright 1998). For such species climate change may form a large threat. The expected pace of climate change is too high for at least as many as ten non-volant species. It is therefore highly unlikely that small bodied species will be able to colonize all patches that become suitable to their needs according to our full dispersal ability scenario. Species that have no or hardly any overlap between their current and their predicted future realized niches, and that are poor dispersers or habitat specialists, like the Siberian flying squirrel (Pteromys Volans), are particularly vulnerable to future climate change. These species therefore risk local extinction in the Barents Region.

We found that even with full dispersal ability eight species are expected to contract their ranges. Three of these species, the wolverine (Gulo gulo), the grey red-backed vole (Myodes rufocanus), and the Siberi- 
an flying squirrel, are already suffering from population decreases according to the IUCN. All but one of these range-contracting species are considered to be habitat specialists, species that have specific habitat requirements as classified using descriptions of habitat use of species in field guides. It is not surprising that most of these species are confined to alpine conditions. These species are associated with conditions that are increasingly disappearing under the pressure of climate change, and we thus expect them to experience increasing habitat loss and fragmentation. Nonetheless, we did not predict any species to go extinct. We did not account for the increased pressure from other species due to expansions or shifts in species ranges and the impact of indirect effects, such as increased competition and predation is likely going to be stronger than the impact of direct impacts of climate change (Callaghan et al. 2004). New communities are likely to form due to expanding geographic ranges of species and colonization of newcomers, increasing the abundance of certain species and lowering that of others. Several species will have to cope with more predator or competitor species in addition to environmental changes. A species like the mountain hare may receive more competition from the European hare (Lepus europaeus), with negative consequences for the first (Thulin 2003). We further predict that species like the tundra vole (Microtus oeconomus) and the European roe deer (Capreolus capreolus) may experience increased predation in parts of their future range. However, positive indirect effects of climate change for these species, such as increased geographic distribution of prey species and increased competition between predators might lessen these effects to some extent. The projected increase in geographic overlap between predators and prey in the future suggests that further studies are needed to predict community-level effects of climate change (Hof et al. 2012b). Especially since climate change can lead to different outcomes of altered species interactions, species may become rare or highly abundant (Van der Putten et al. 2010), and the importance of biotic interactions in predicting species' future ranges has already been shown (Hof et al. 2012a; Araújo and Luoto 2007). 
The West-european hedgehog (Erinaceus europaeus). One of the species predicted to benefit from climate change

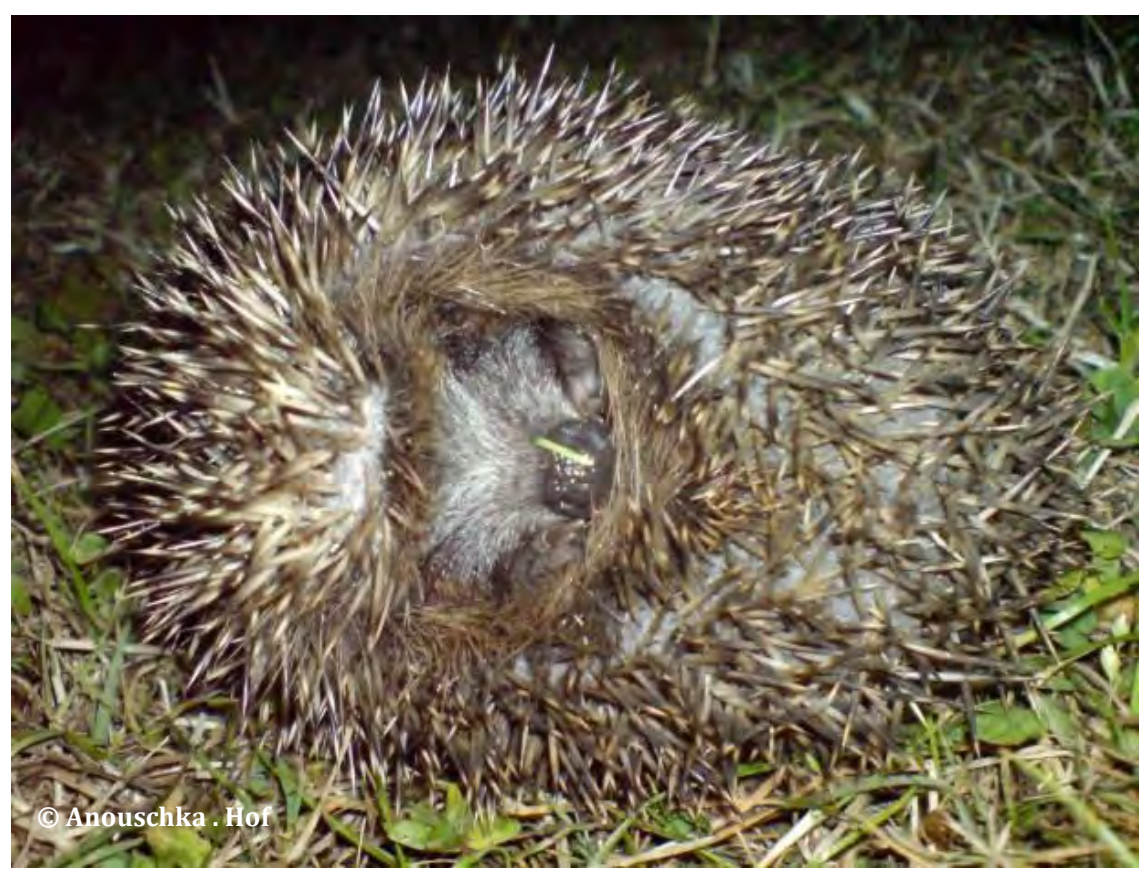

We conclude that climate change in the Barents Region does not necessarily equate to substantial loss of species, provided that dispersal ability is not hampered. However, changes in species interactions, limitations to successful colonization and human impacts related to climate change may threaten species, even when areas are predicted to still be largely suitable to their environmental needs under new climatic conditions. Our study has clear implications regarding the necessity to include future climate change and concurrent changes in community composition in conservation planning. Current protected areas may not provide species with their future requirements (Araújo et al. 2011). Although none of the species assessed is predicted to go regionally extinct, we provide evidence that the vulnerability of already threatened species may increase due to the introduction of new competing/predatory species in their geographic range. We also stress the importance of habitat connectivity and of the existence of sufficient and appropriate corridors to allow dispersal between suitable habitats for the future persistence of various species. 
Figure 21. The current and future predicted mammal species richness in the Barents Region. BCS (best case scenario): all mammals are able to fully disperse to their new climatic niches. WCS (worst case scenario): all mammals are only able to persist in areas that are currently suitable to their climatic needs and remain to be so in future. The predictions are based on the CGM2 A2 scenario for 2080

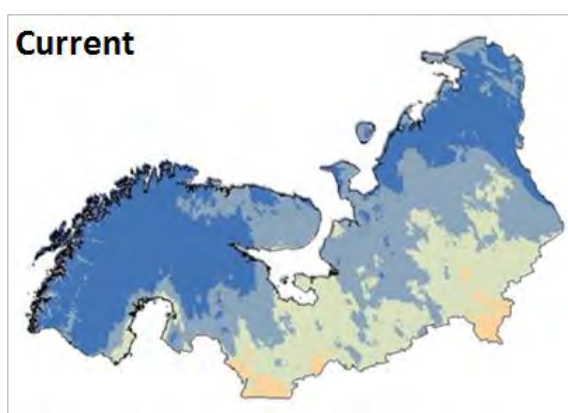

Number of mammal species
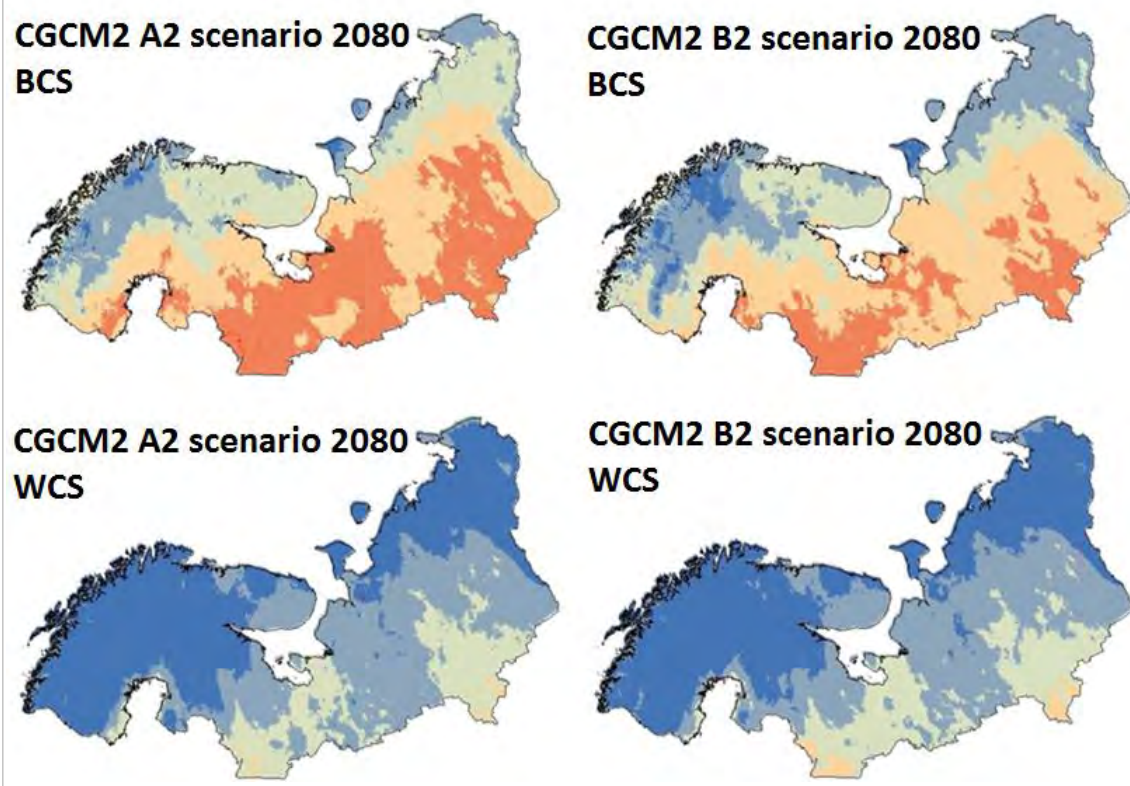
Figure 22. Figure showing the net change in suitability for mammals to occur between current situations and 2080 in the Barents Region, assuming species are able to disperse fully to their new climatic niches

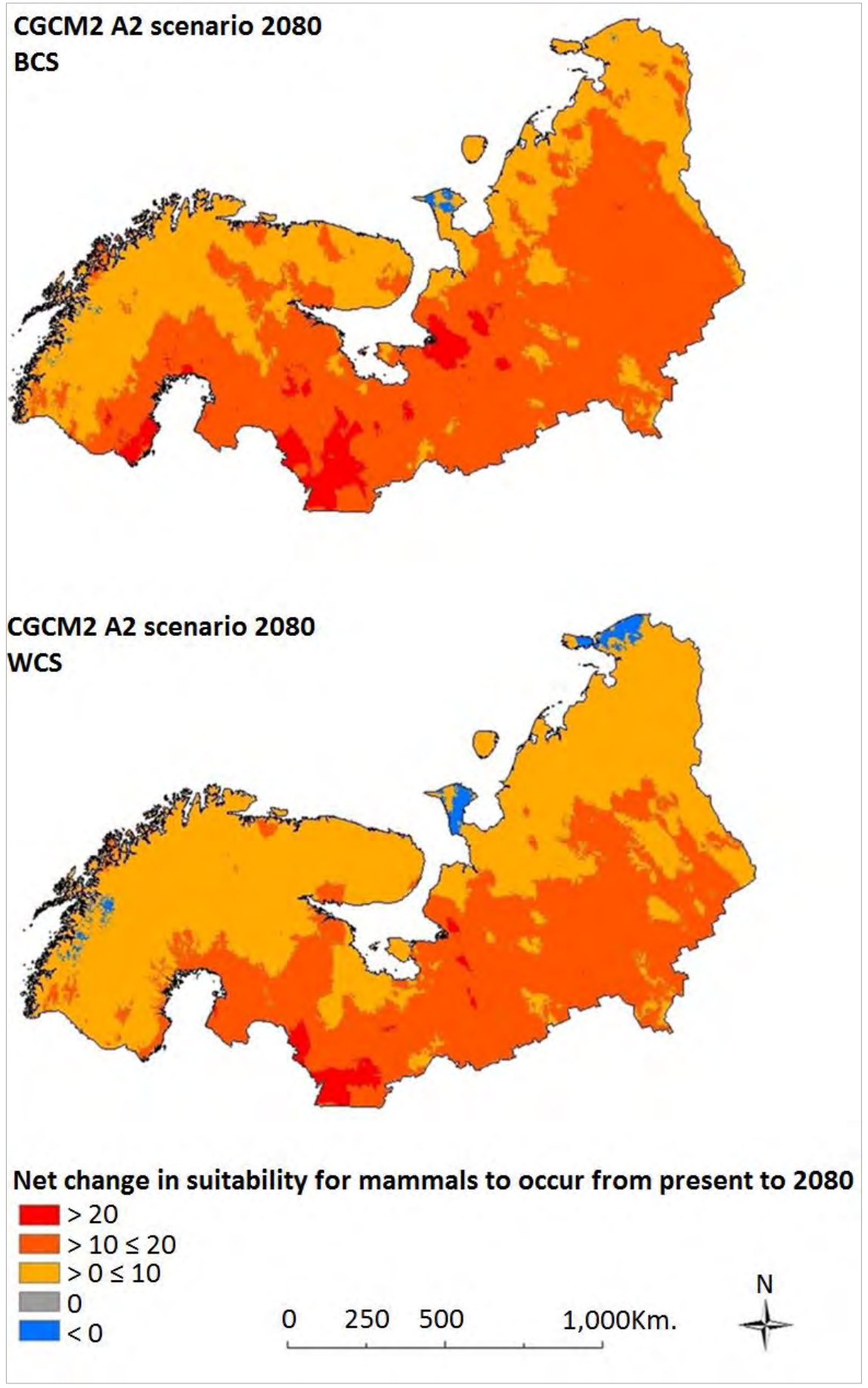




\subsection{The Arctic fox}

Although the Arctic fox is globally classified as least concern by the IUCN red List of threatened species, the Fennoscandian population is assessed as critically endangered (Hersteinsson et al. 2006). Many efforts to safeguard this population have been initiated over the past few decades. Not only are there breeding programmes, additional feeding and culling red foxes (Vulpes vulpes) are amongst the efforts taken as well. However, these efforts have not resulted in a more healthy Arctic fox population in Fennoscandia. This failure is likely caused mainly by an increasing and continued competition from the red fox (Hersteinsson and Macdonald 1992; Tannerfeldt et al. 2002; Selås and Vik 2007). Arctic foxes tend to avoid areas with red foxes (Tannerfeldt et al. 2002). They are also the inferior competitors over resources like carcasses and den sites (review in Hersteinsson and Macdonald 1992). In addition, red foxes also frequently kill juvenile Arctic foxes (Tannerfeldt et al. 2002), and can eradicate entire Arctic fox populations on islands (Bailey 1992; citations in Hersteinsson and Macdonald 1992). Although the Arctic fox generally occurs in colder areas than the red fox, parts of their ranges overlap. In fact, the southern range limit of the Arctic fox is determined by the presence of the red fox (Hersteinsson and Macdonald 1992). The northern limit of the distribution of the red fox is on the other hand determined by climate related resource availability. It is therefore plausible that the red fox will be able to shift its range northwards with climate change. Future climate change may therefore form a further threat to the persistance of arctic foxes in Fennoscandia (also see Fuglei and Ims 2008). This is not only because of the physical requirements of the Arctic fox (Fuglei and Øritsland 1999), but also because the area of sympatry with the red fox will likely expand in future (Hersteinsson and Macdonald 1992).

\section{The red fox is an important competitor and predator of the Arctic fox}

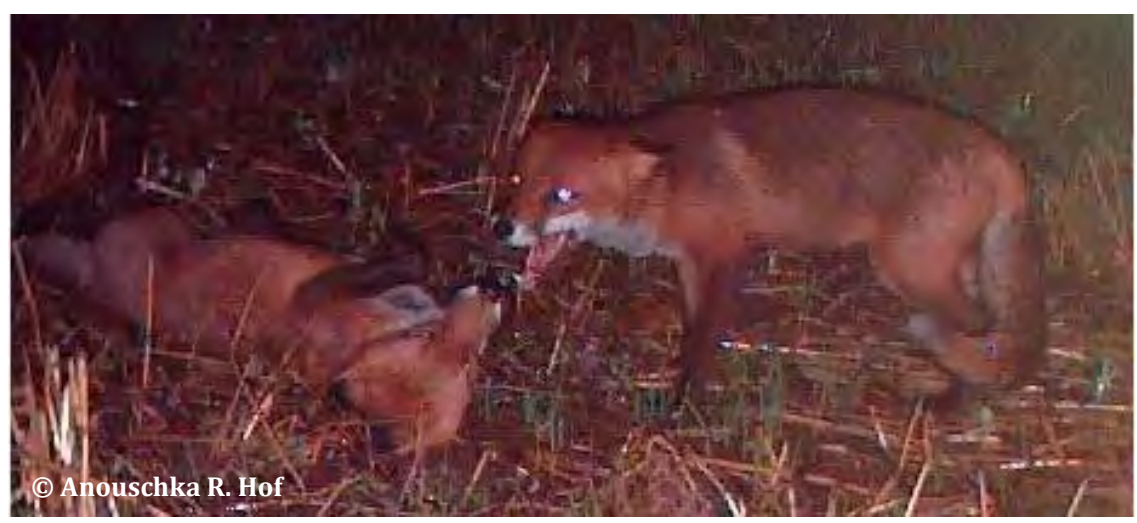


Another important factor that may have caused Fennoscandian Arctic fox numbers to fall during the last century is related to its dietary requirements. Although the Arctic fox is an opportunistic omnivore (Dalerum and Angerbjörn 2000), the Fennoscandian population belongs to a so-called lemming ecotoon (Braestrup 1941). This means that they specialize in lemmings (Lemmus sp.) (Kaikusalo and Angerbjörn 1995; Angerbjörn et al. 1999; Dalerum and Angerbjörn 2000; Elmhagen et al. 2000). In the past the numbers of the Fennoscandian Arctic fox has reflected the abundance of the Norway lemming (Lemmus lemmus) (Angerbjörn et al. 1995, 1999; Kaikusalo and Angerbjörn 1995). If climate change would negatively affect the abundance of the Norway lemming, this may prove negative for the Arctic fox, and perhaps a whole range of other predators, as well. We therefore accounted for the predicted future distribution of the red fox and the Norway lemming while assessing how future climate change may impact the Arctic fox in Fennoscandia. This effort should result in more realistic predictions of the response of the Arctic fox to climate change, which will help to formulate better conservation strategies. 
Figure 23. The former and current distribution range of the Arctic fox in Fennoscandia, taken and adapted from Angerbjörn et al. (2005)

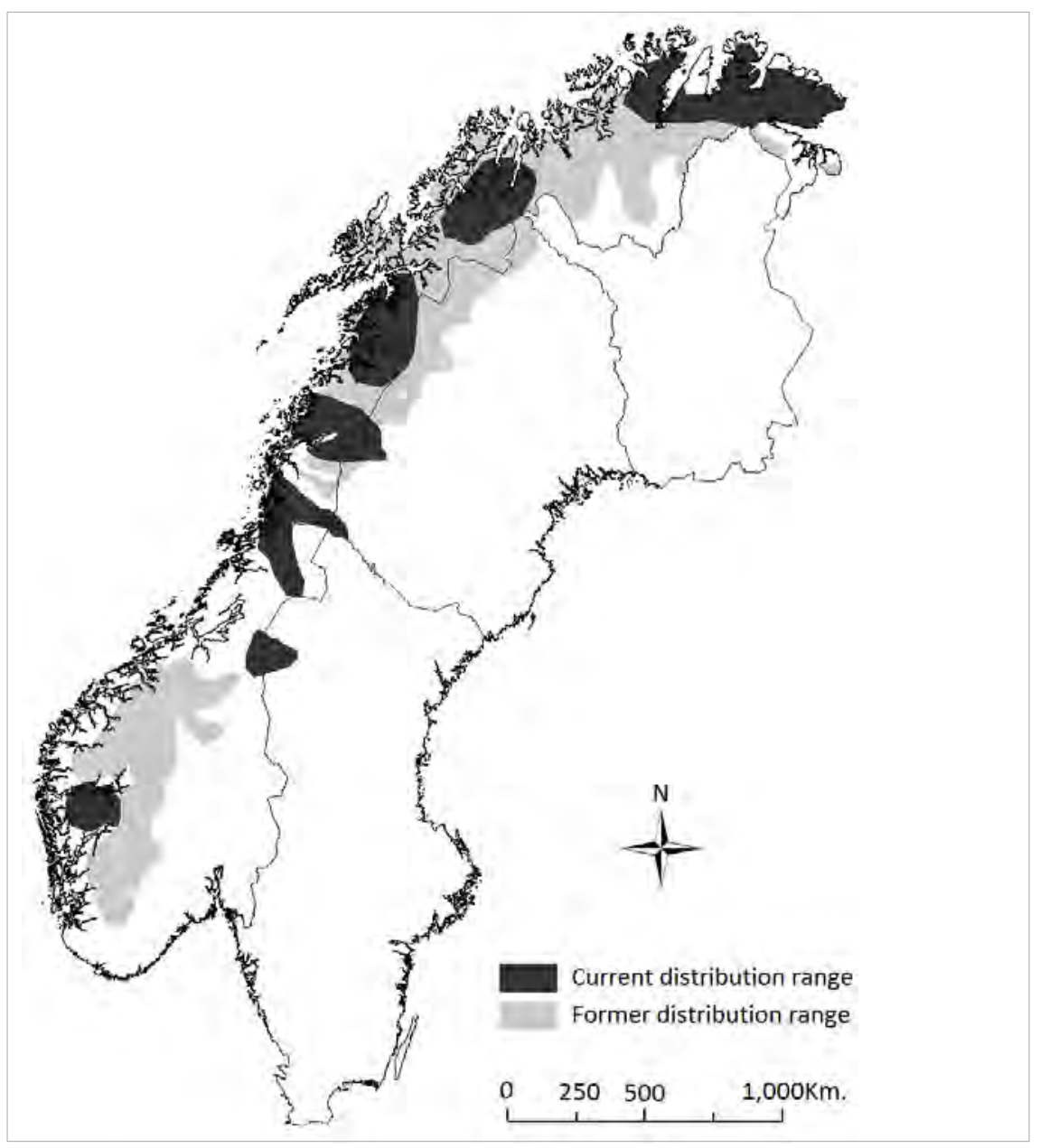


Figure 24. The current and future (2080) predicted range of the Arctic fox when accounting for: (blue and red) climate only, (blue) climate and species interactions. Predictions are based on the CGM2 A2 scenario for 2080

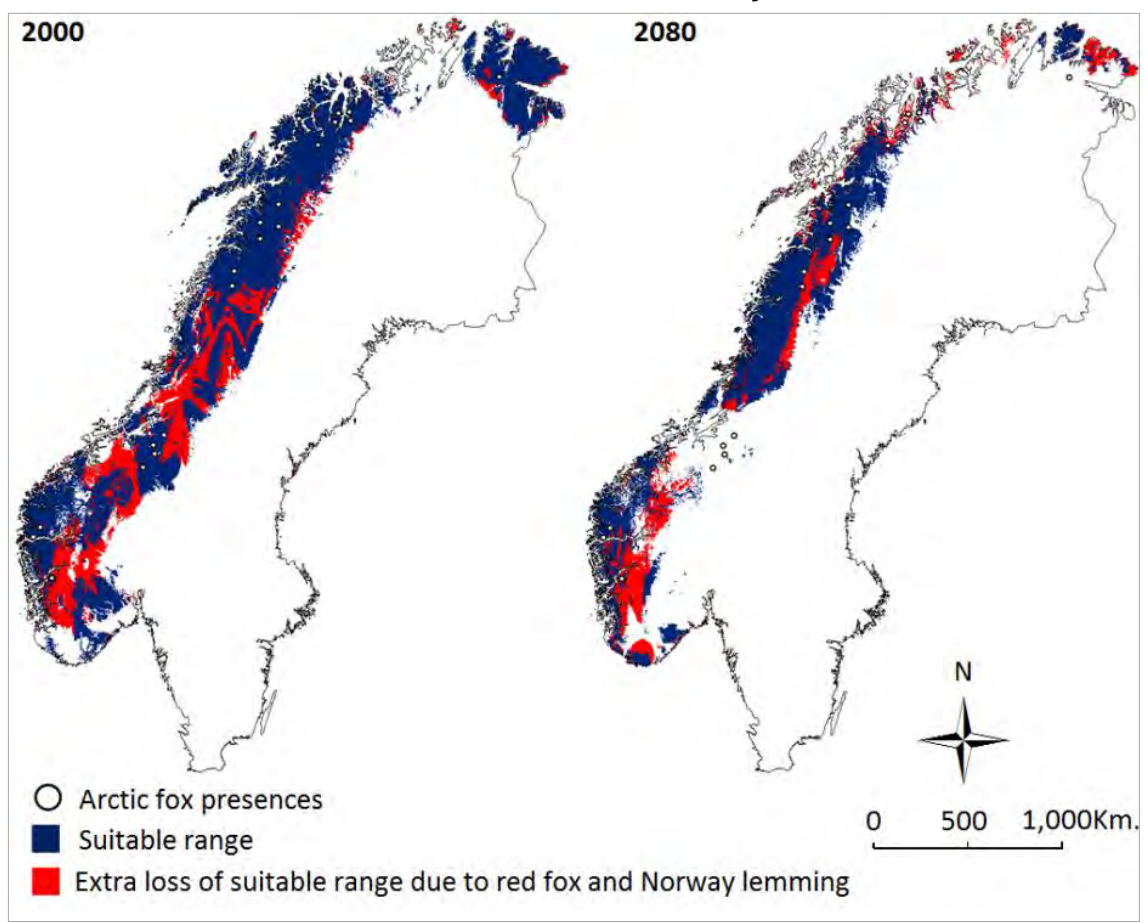

Figure 23 shows the former and current distribution range of the Arctic fox in Fennoscandia. When we compare this figure with Figure 24, we clearly see that accounting for the presence (or absence) of the red fox and the Norway lemming the current prediction of which part of Fennoscandia is suitable for the Arctic fox improves. We therefore assume that accounting for these species also improves the prediction of where the region may be suitable for the Arctic fox in future.

Figure 24 further clearly shows that the future range of the Arctic fox may decrease to a large extent, and that some current strongholds may no longer be suitable in future. This lack of continued suitability is partly due to direct impacts of changing environmental conditions on the Arctic fox, but also due to indirect impacts of changing environmental conditions. Some regions will become suitable for the red fox. This species is thought to be able to benefit from climate change and expand its range. However, the models predict that climate change will, likewise as for the Arctic fox, be negative for the Norway lemming. This species is a cold-climate specialist and will likely decrease its range in future, which feeds back to the Arctic fox. The importance of accounting for such species interactions is illustrated by Figure 25. The protected area shown in this figure is 
Børgefjell. When species interactions would not be taken into account we may believe the entire protected area is suitable for the Arctic fox to occur in future (Figure 24, 2000). However, when we account for the presence of the red fox and the Norway lemming we discover that half of the protected area will not be suitable any longer for the Arctic fox to occur in future (Figure 24, 2080).

Figure 25. An example of how not accounting for species interactions may affect management decisions in protected areas

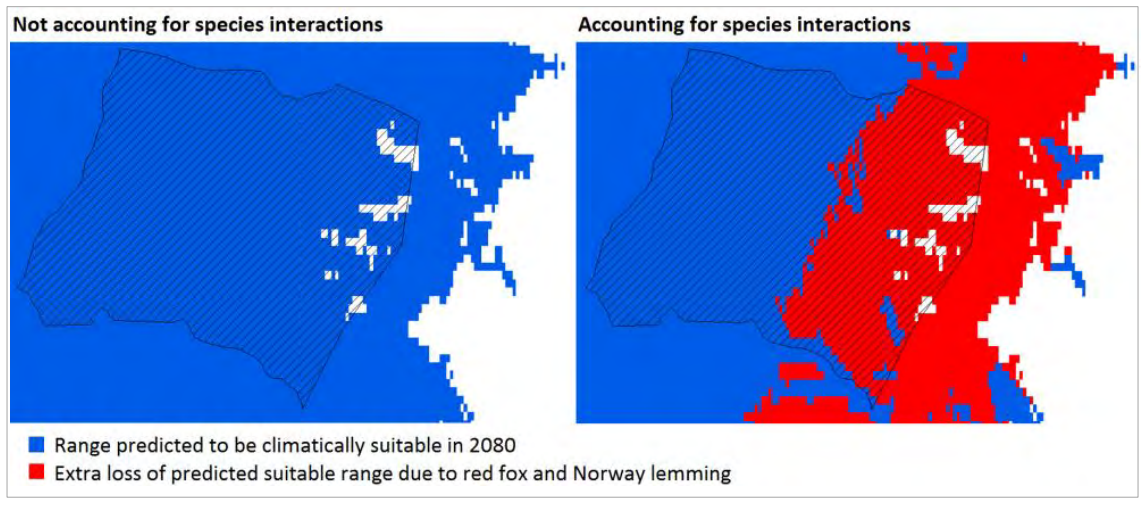

From this study we may conclude that in the absence of conservation actions, the future looks grim for the Fennoscandian population of the Arctic fox. The population is currently critically endangered, and it is already unable to utilize its full potential geographic range (Figure 23; Hersteinsson and Macdonald 1992; Angerbjörn et al. 2005). Its extinction risk is enhanced by increased fragmentation of the existing population (Herfindal et al. 2010). A warming climate combined with an increased threat of competition from the red fox, and a decrease of abundance of the Norway lemming may cause the local extinction of this population, unless immediate action is taken. The control of the abundance and northward spread of the red fox is already used as a management action in Sweden and Finland (Angerbjörn et al. 2008). This may be even more important in the future to preserve the Fennoscandian Arctic fox population. Arctic foxes in Sweden are already fed during parts of the year to increase survival (Angerbjörn et al. 2008). Managers and nature conservationists may also consider increasing their efforts to provide supplementary food to the Arctic fox. It must however be mentioned that Henden et al. (2010) argue that increased food abundance may favour red foxes. This may subsequently negatively affect Arctic foxes. Both Arctic fox and Norway lemming populations fluctuate widely in numbers among years (Angerbjörn et 
al. 1995). We were not able to take this into account in our analyses. These fluctuations increase the risk that the Fennoscandian population of Arctic fox might go extinct for stochastic reasons. It is therefore recommended that conservation management intensities should relate to the current phase in the population cycle to maximize effectiveness (Henden et al. 2009). To conclude, since both red fox culling and supplementary feeding are management actions already used, these are likely to be increasingly important for the future survival of Fennoscandian Arctic fox populations. 



\section{Reptiles}

Reptiles, like amphibians, are ectotherms and like amphibians, they are globally declining. Climate change has been mentioned as one reason for this decline (Gibbons et al. 2000). Possibly one of the largest consequences climate change may have on this class of species if that certain reptiles have temperature dependent sex-determination of hatchlings (Janzen 1994). Furthermore, since reptiles are slow dispersers, shifts in climatic niches may also form a large threat. We assessed the impact of climate change on the geographic distribution of six reptile species currently occuring in or just south of the Barents Region: the smooth snake (Coronella austriaca), the grass snake (Natrix natrix), the common European adder (Vipera berus), the slow worm (Anguis fragilis), the sand lizard (Lacerta agilis), and the viviparous lizard (Zootoca vivipara) (also see Appendix Table 1e.). Of these six species, the sand lizard may be able to establish itself in the Barents Region in future (Figure 26). At present it is not occurring in the Barents Region, but the species has been recorded south from the region.

From Figure 26 it becomes clear how important it is to take dispersal ability into account. Reptiles are slow dispersers. Whilst the sand lizard may be able to reach some areas in the south of the region that become climatically suitable for the species to occur, it is highly unlikely that it will reach the potentially suitable areas in the north of the region. The five other species were all expected to expand their ranges. All species were expected to shift their geographic distribution to the north. However, three species are expected to go northwest, whilst the other three were expected to go northeast. 
Figure 26. Future climatic suitability of the Barents Region for the sand lizard to occur

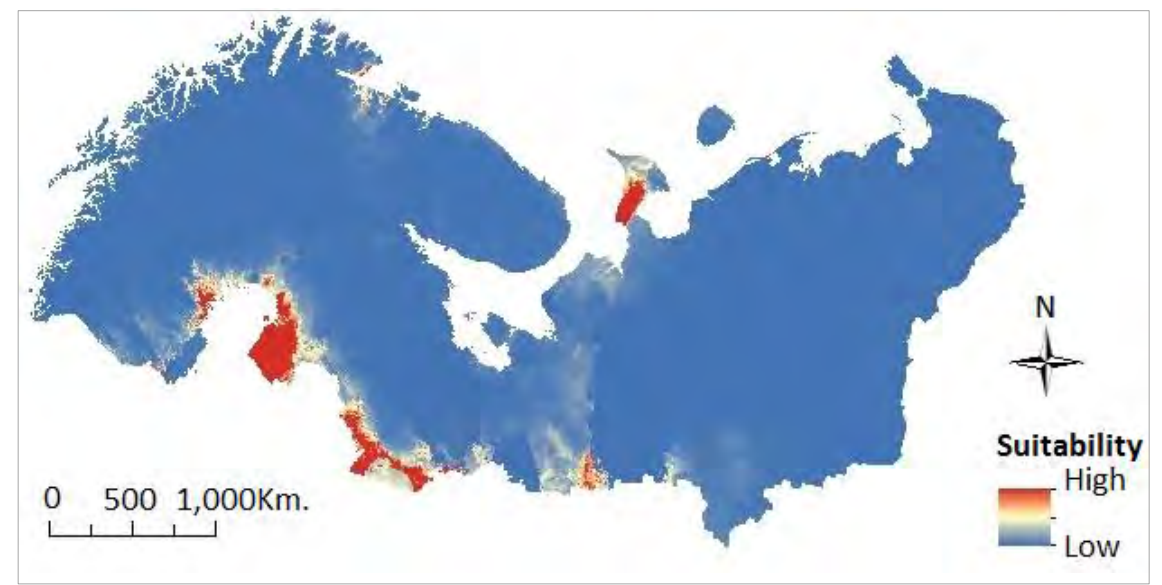




\section{Trees and plants}

A limited number of species of the kingdom Plantae was assessed: 116 species. The results presented below are therefore not necessary representative for the impact of future climate change on tree and plant species in the Barents Region. Of the species assessed, 27 do not occur or are very rare (present in $<0.1 \%$ of the Barents Region) at present. However, all of these species are predicted to be able to become marginally or a lot more common in future because of improving climatic conditions, if they are able to disperse. One of these species is the crested wood fern (Dryopteris cristata). This species is associated with wetlands and temperate to subarctic climates (Landergott et al. 2001). Warmer and wetter conditions in the Barents Region may therefore benefit this species. The majority $(n=89)$ of the species assessed were however already established in the Barents Region. Climatic conditions for nearly all of these $(n=82)$ were predicted to become better. This may be positive for a large range of species but may also have negative consequences. A species like the European silver fir is currently, although rare in the Barents Region, classified as invasive in both Norway and Sweden according to the European Network On Invasive Alien Species (http://www.nobanis.org/). The prediction that nearly a third of the Barents Region may become suitable for its needs may therefore present difficulties for a range of other species. On the other hand, Elling et al (2009) suggest that the European silver fir may be used as an alternative to Norway spruce (Picea abies) for forestry practices in future, as this species has a higher resistance to drought, storm and bark beetle attacks when conditions are suitable to its needs.

Only seven species of the species assessed are thought to decrease their range in future. These were the Alpine bearberry (Arctostaphylos alpina), the Alpine lady-fern (Athyrium distentifolium), the pygmy buttercup (Ranunculus pygmaeus), the dwarf willow (Salix herbacea), the polar willow (Salix polaris), and the purple saxifrage (Saxifraga oppositifolia), which are all related to cold-climate habitats, and lanceleaf grapefern (Botrychium lanceolatum), which is related to pastures, haymeadows and roadsides. Figure 27 shows the mean percentage of the area in the Barents Region that is predicted to be climatically suitable for plant species of nine orders for which we assessed a relatively large number of species. 
Figure 27. The mean percentage area of the Barents Region that is predicted to be suitable for plant species of the most common orders assessed in 2000 (C), and in 2080 ( $B$ = Best case scenario: all species are able to fully disperse and utilize their future climatic niche, $W=$ Worst case scenario: none of the species is able to disperse beyond its current climatic niche but they are all able to maintain in the areas they occupy at present) under the CGM2 A2 scenario for 2080

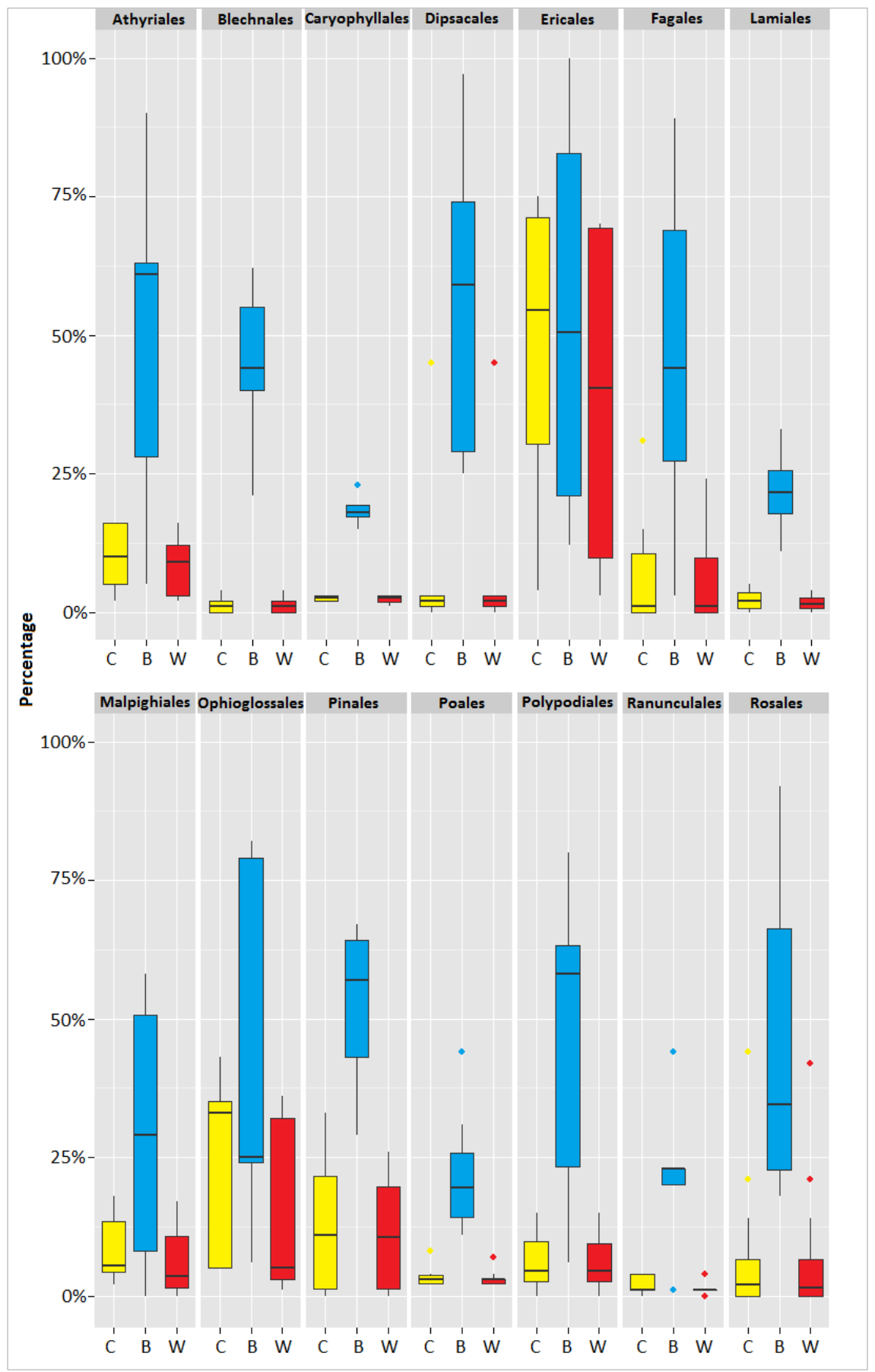




\section{Land use and protected areas}

The objective of this project was to identify future hotspots of species diversity and the possible need for additional protected areas in the Barents Region. We included in total 399 species representing 5 classes in the analyses: amphibians $(\mathrm{n}=12)$, birds $(\mathrm{n}=231)$, butterflies and moths $(n=92)$, mammals $(n=65)$, and reptiles $(n=6)$. We excluded 62 species from the analyses because we either were unable to obtain sufficient species occurrences or the performance of the models was deemed unsufficient. Analyses were therefore limited to 337 species (See Table 2a-e in the appendix). In chapters 4, 5, 6, 7 and 9 we reported on the findings for the specific taxonomic classes. Here we report on general findings and the results of the spatial conservation planning using Zonation.

In total $57 \%$ of all species assessed were predicted to be able to increase their geographic distribution range in the Barents Region in future (Figure 28). However, $10 \%$ of the species may become losers and $4 \%$ may even lose their entire range in the region. (NB we classified species as near extinct when their geographic distribution range comprised $<0.5 \%$ of the Barents Region). There were seven species for which the models predicted that there will not be any region climatically suitable for them to occur. Amongst these were two bird species, the red-flanked bluetail (Tarsiger cyanurus) and the Siberian jay (Perisoreus infaustus), and five butterflies/moths, the dingy fritillary, the mountain fritillary, the pale arctic clouded yellow, the scarce heath, and the Alpine grizzled skipper. It must however be noted that more detailed research is needed to confirm these findings.

Figure 28. The fate of the species assessed

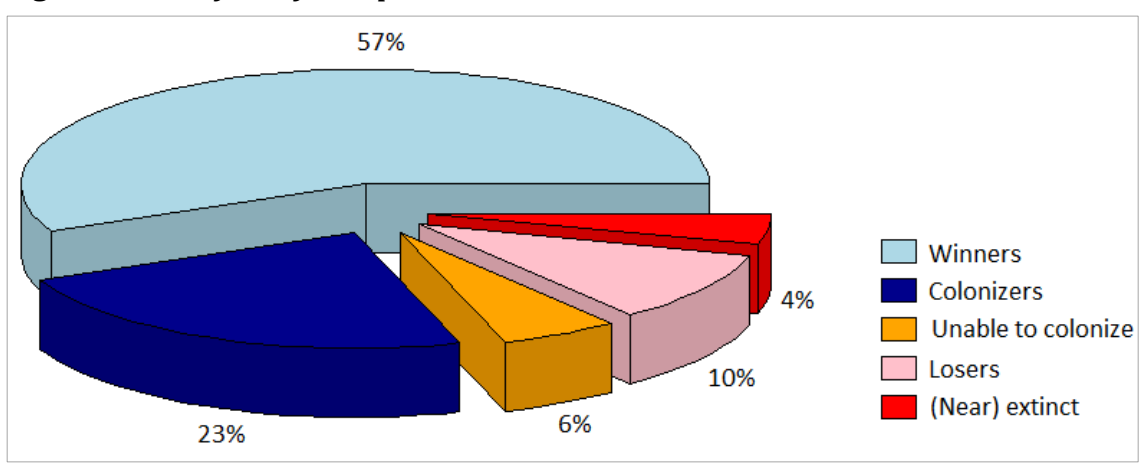


The general trend for all classes assessed was that species richness may increase in the Barents Region in future if species are able to disperse and fully utilize their future climatic niches (Figure 29). However, when species are not able to disperse beyond their current climatic niche, but are able to maintain in the areas they occupy at present, species richness will decrease. The truth is likely to lie somewhere in between these scenarios where some species are able to disperse fully, some only partly and some not at all. It is however difficult to account for dispersal rates of species and at best they are based upon estimates. Not only are the dispersal rates for many species unknown, poorly documented or highly fluctuating, species may unintentionally be introduced to new areas by humans. This occurs relatively often amongst for instance insects. Roques et al. (2009) report that approximately $90 \%$ of the alien invertebrates present in Europe were unintentionally introduced through human activity. Such unintentional introductions often occur via "stowaway" or via the transport of goods. We envisage that volant mammals and birds may be able to adjust their ranges without dispersal limitation. Their average dispersal rate is estimated to be $25 \mathrm{~km}$ yr-1 (Gaston and Blackburn 2002). Non-volant mammals disperse on average considerably slower, especially small mammals. The average colonization rate of the invasive grey squirrel (Sciurus carolinensis) and muskrat (Ondatra zibethicus) was approximately $7.9 \mathrm{~km}$ yr-1 (Fløjgaard et al. 2009). Although large predators and ungulates may easily reach this rate, small rodents may not. Lepidoptera are apt dispersers with reported dispersal rates between 3-170 km yr-1 (Liebhold and Tobin 2008; Parmesan et al. 1999). Amphibians are generally thought to be slow dispersers (Blaustein et al. 2001) with a number of exceptions that are able to disperse remarkably far (Funk et al. 2005; Smith and Green 2005). The median rate for a large number of amphibian species was $0.5 \mathrm{~km}$ yr-1 (Smith and Green 2005). The best case scenario is therefore unlikely to be reached by amphibians. Reptiles on the other hand are thought to be more apt colonizers (Carlquist et al. 1965). The smooth snake is for instance able to disperse $\sim 4.9 \mathrm{~km}$ yr-1 (Gent and Spellerberg 1993). 
Figure 29. Boxplot of the percentage of the Barents Region covered by the geographic distribution ranges of all species present in the Barents Region at present $(C)$ and in 2070 (B = Best case scenario: all species are able to fully disperse and utilize their future climatic niche, $W=$ Worst case scenario: none of the species is able to disperse beyond its current climatic niche but they are all able to maintain in the areas they occupy at present) according to the 4.5 Representative Concentration Pathway of the downscaled general circulation model HadGEM2-ES

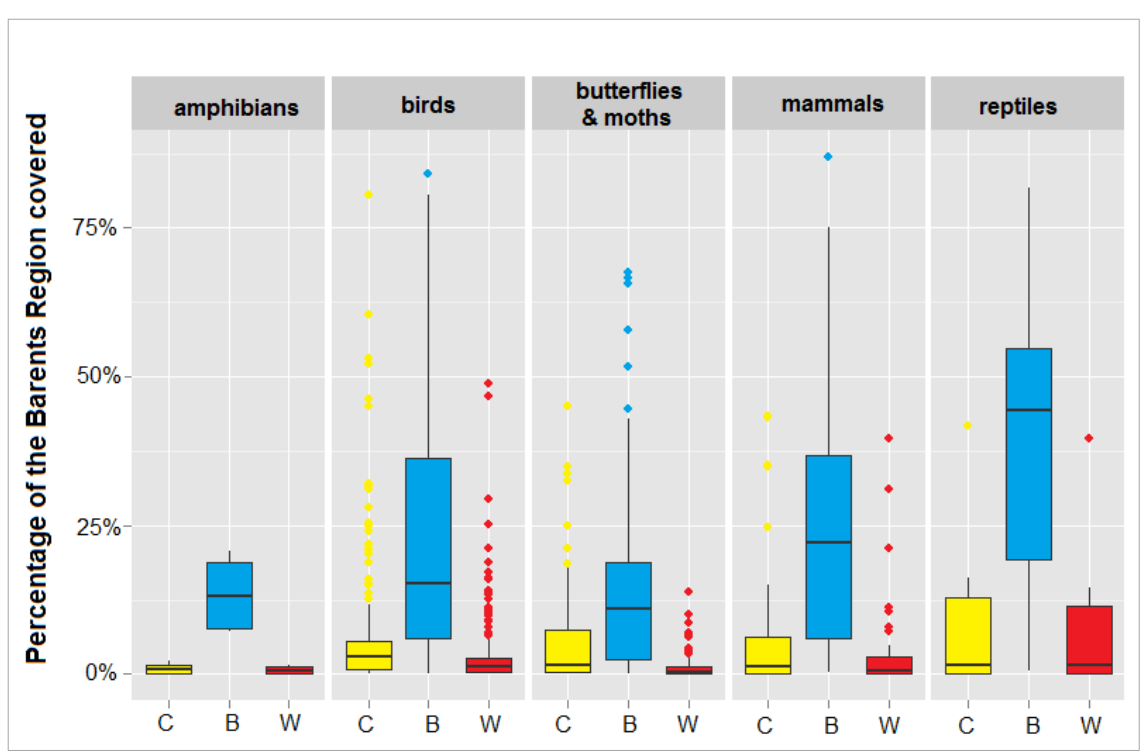

Changes in the mean annual temperature were most often related to changes in the geographical distribution of species (Figure 30). In total $38 \%$ of the species assessed responded most strong to changes in this variable according to the modelling. These species were primarily amphibians, birds and mammals. A further $25 \%$ was related most strongly to the mean temperature of the warmest quarter of the year. These species were primarily butterflies and moths, and reptiles. Landcover was the most important predictor of a number of birds that have a strong preference for certain habitat types like the little gull (Larus minutus) that breeds on freshwater marshes.

Figure 30. The frequency of occurrence of the most important predictor variables

Annual mean temperature
$\begin{aligned} & \text { Mean temperature of the warmest quarter } \\ & \text { Mean temperature of the warmest month } \\ & \text { Population density } \\ & \text { Temperature seasonality } \\ & \text { Landcover }\end{aligned}$
$\begin{aligned} & \text { Mean temperature of the wettest quarter } \\ & \text { Other }\end{aligned}$


The spatial conservation planning exercise showed us that there is large overlap in areas that need prioritization in conservation among classes (Figure 31). Especially the coastal areas of Fennoscandia and the southwestern parts of Northwest Russia should receive prioritization for conservation. These areas are going to be climatologically increasingly suitable for a large range of species to occur. However, these areas also have the highest human activity with the highest human population density. The majority of the large protected areas that currently exist within the region are situated in areas where the priority for conservation remains low. It is therefore anticipated that additional areas in the Barents Region may need to be protected, or that land outside protected areas are managed to accommodate new species. However, political and socio-economic issues may undermine choosing the areas that are predicted to have the highest biodiversity. Organizational, social, economic and logistical factors may overrun ecological choices in practice and although the cost component in conservation priority setting is often neglected (Carwardine et al. 2008), resources are not endless. In addition, some species may need to receive extra attention. We partly incorporated this by adding extra weight to species currently listed on the IUCN red list for threatened species. Nevertheless, more detailed studies focusing on particular species in combination with assessments of what is possible economically, politically, logistically and socially is necessary to optimize conservation.

\section{The little gull prefers to breed on freshwater marshes}

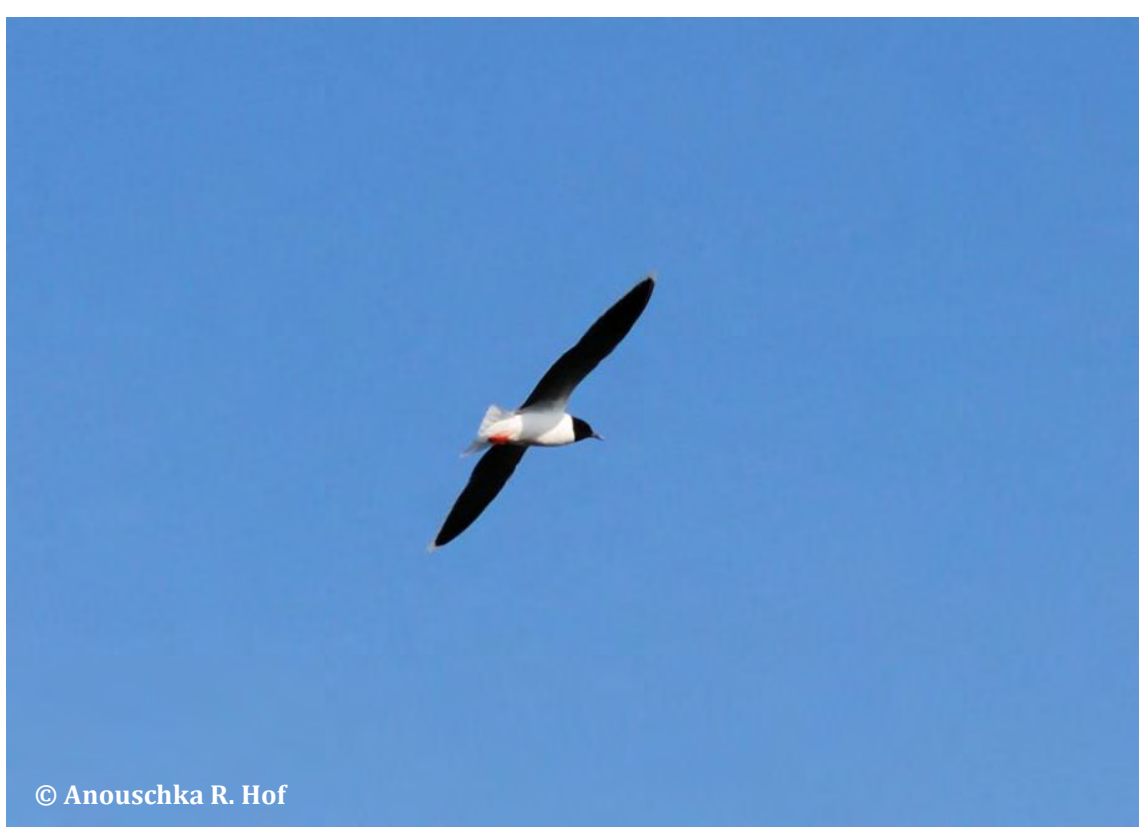


Figure 31. Areas that need prioritization for different classes. The majority of existing protected areas are shown for reference. A large number of these are classified as low priority for receiving conservation effort because they already receive protection

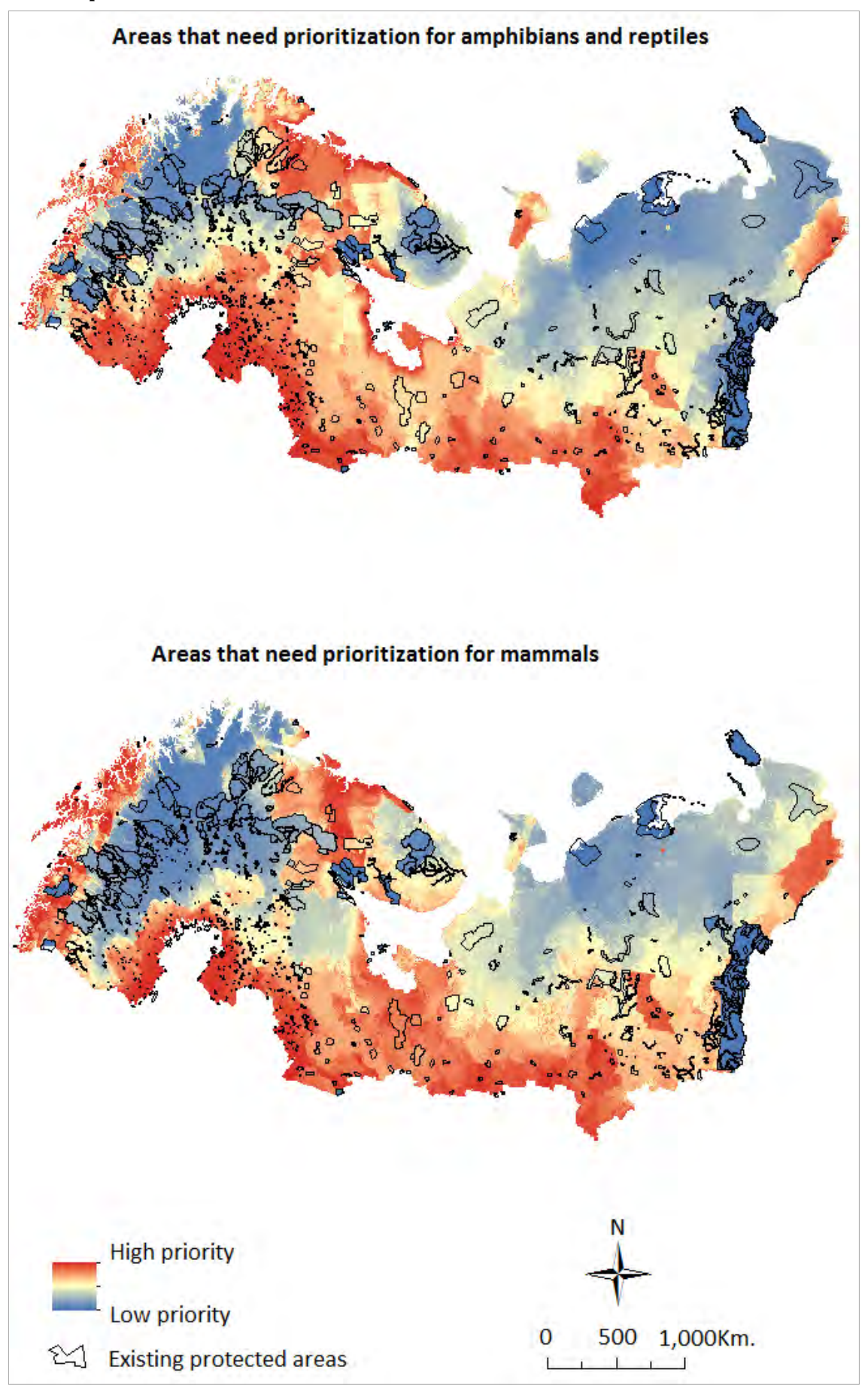





\section{Svensk sammanfattning}

Klimatet ändras snabbt vilket påverkar utbredningen och mängden av många arter. För att bevara biologisk mångfald är det viktigt att lära sig mer om hur klimatförändringar kan påverka de arter som redan finns i Barentsområdet, dvs. norra delarna av Norge, Sverige och Finland samt nordvästra Ryssland, och de arter som kan tänkas etablera sig i området i framtiden. Detta projekt finansierades av Nordiska ministerrådet och utfördes av Landskapsekologigruppen vid Institutionen för ekologi, miljö och geovetenskap vid Umeå universitet och hade följande syften:

- Att bedöma effekterna av klimatförändring på arterna i Barentsområdet.

- Att utvärdera hur effektivt det befintliga nätverket av skyddade områden värnar arterna i Barentsområdet vid klimatförändring.

- Att ge råd och rekommendationer för att anpassa ekosystemförvaltning och bevarandestrategier i Barentsområdet.

- Att bedöma effekten av förutsedda ökningar av mänsklig påverkan och markanvändningsförändringar på framtida artsamhällen $\mathrm{i}$ Barentsområdet.

Vi använde en rad modelleringstekniker och litteraturöversikter för att bedöma klimatförändringens påverkan på den biologiska mångfalden genom att studera ungefär 500 arter av groddjur, dagfjärilar, fåglar, däggdjur, nattfjärilar, växter, sniglar och kräldjur. Dessutom undersökte vi ett flertal arter mer i detalj. De viktigaste resultaten var:

- I framtiden kommer Barentsområdet att vara fuktigare och varmare än idag. Vegetationen kommer i högre grad att domineras av barrskog medan gräsmarker blir mycket ovanliga.

- Artrikedomen kan öka i Barentsområdet i framtiden om arter kan spridas och fullt utnyttja sina framtida klimatiska miljöer. Om arter inte kan sprida sig utanför sina nuvarande klimatiska miljöer, men ändå hålla sig kvar, kommer artrikedomen att minska i framtiden. Därför rekommenderar vi en utvidgning av nätverket av skyddade områden samt ett skapande av möjliga spridningsvägar för att ge 
arter möjlighet att sprida sig mellan sina nuvarande och framtida klimatiska miljöer.

- Förutom de effekter framtida klimatförändringar kan ha på arter bör även arter med livsegenskaper som kan vara potentiella riskfaktorer i en varmare miljö, som om arterna flyttar eller inte och om arterna är känsliga för rovdjur eller inte, beaktas när man utformar bevarandestrategier.

- Specialister på kalla klimat och arter som sprids långsamt är särskilt sårbara och kan även utrotas lokalt. Möjliga negativa effekter av klimatförändring, såsom ökad konkurrens och predation, anses skapa stora utmaningar för specialister på kalla klimat. Dessa effekter ska därför inte försummas.

- Det är viktigt att beakta artinteraktioner vid bedömning av en arts sårbarhet vid klimatförändring. Om ett betydelsefullt rovdjur exempelvis anses gynnas av klimatförändring kommer ett stort antal bytesdjur också att påverkas märkbart, oberoende av huruvida bytesdjuret gynnas av klimatförändring eller inte. På samma sätt kan en möjlig minskning av ett viktigt bytesdjur, såsom fjällämmel, orsaka en minskning av en hel rad rovdjur, oberoende av om rovdjuren gynnas av klimatförändring eller inte.

- De områden som behöver prioriteras när man utvecklar nätverket av skyddade områden är belägna i Fennoskandiens kusttrakter och i de sydvästra delarna av nordvästra Ryssland. Dessa områden kommer att bli klimatiskt mer lämpade för ett stort antal arter. Dessa områden har emellertid också den högsta mänskliga aktiviteten och politiska och socio-ekonomiska förhållanden kan underminera ett skydd av de områden som förutsägs få den högsta biologiska mångfalden.

- Organisatoriska, sociala, ekonomiska och logistiska faktorer kan omintetgöra ekologiska val i praktiken och även om kostnaden för naturvårdsprioriteringar ofta förbises är resurserna inte oändliga. Detta manar till att sköta landskap och regioner på ett sätt som medger samexistens av människor och andra arter. Mer detaljerade studier som fokuserar på särskilda arter i kombination med bedömningar av vad som är möjligt ekonomiskt, politiskt, logistiskt och socialt är nödvändiga för att optimera bevarande.

Vi fann att specialister på kalla klimat är särskilt sårbara inför klimatförändringar. Detta är inte förvånande eftersom Barentsområdet anses bli fuktigare och varmare i framtiden. Dessa arter kan komma att förlora 
ansenliga delar av sina geografiska utbredningsområden i Barentsregionen i framtiden och deras bevarande bör prioriteras. Arter som förtjänar omedelbar uppmärksamhet är de för vilka modellerna förutsade att miljöförhållandena inte längre kommer att vara lämpliga i området $\mathrm{i}$ framtiden. Bland dem finns två fågelarter, blåstjärten (Tarsiger cyanurus) och lavskrikan (Perisoreus infaustus), och fem dagfjärilar/nattfjärilar: dvärgpärlemorfjärilen (Boloria improba), fjällpärlemorfjärilen (Boloria napaea), fjällhöfjärilen (Colias werdandi), den bruna gräsfjärilen (Coenonympha hero), och blomvisslaren (Pyrgus andromedae). Vi rekommenderar noggranna studier för att bekräfta våra fynd och för att undersöka andra faktorer som kan innebära problem för dessa arter. Indirekt påverkan av klimatförändring, såsom ökad konkurrens och predation, och minskad födotillgång, kan bli allvarlig. Det kan också finnas en hel rad andra hot mot arterna, såsom förstörelse av livsmiljöer, jakt, oljespill och annan antropogen påverkan. Dessa hot är sannolikt inte begränsade till de politiska gränserna för Barentsområdet. Gränsöverskridande insatser bör därför göras. Dessutom kommer detaljerade studier att ge en bättre insikt om vilka arter som bör bevaras på en mer detaljerad nivå och vilka ytterligare åtgärder som bör vidtas. Kontroll av rovdjur, tillförsel av extra föda, begränsningar av jaktandelar eller att ge särskilda arter skyddsstatus kan vara viktiga åtgärder. Fördjupade studier av de arter som hotas kan ge nödvändig kunskap för att utforma förnuftiga bevarandeplaner och -strategier.

De klimatiska förhållandena för de flesta arter vi studerat bedöms bli bättre. Artrikedomen bedöms därför komma att öka i Barentsområdet i framtiden. Det är emellertid inte säkert att arterna kan nå sina framtida klimatiska miljöer. Detta är i högsta grad beroende av deras spridningsförmåga och av tillgången på lämpliga spridningsvägar. Även om lättspridda arter, såsom de flesta fåglar och fladdermöss, troligtvis är väl anpassade för att kolonisera små isolerade livsmiljöer, även om deras livsmiljökrav är restriktiva, är de flesta grod- och kräldjur och även ett antal däggdjur som hasselmusen (Muscardinus avellanarius), starkt beroende av sammanhängande livsmiljöer för att kunna spridas till nya områden. Assisterad spridning kan därför vara en möjlighet för ett begränsat antal arter, förutsatt att arterna inte stör de nuvarande ekosystemen. Det är emellertid viktigt att det finns ett vidsträckt nätverk av spridningskorridorer som binder samman skyddade och andra lämpliga områden. Sådana korridorer och nya skyddade områden kan bäst placeras i kustområden i Fennoskandien och i de sydvästra delarna av nordvästra Ryssland. Organisatoriska, sociala, ekonomiska och logistiska faktorer kan dock överskugga de ekologiska alternativ som beaktas när 
områden får bevarandeprioritet. Vi rekommenderar därför att undersöka möjligheter att bevara arter i samarbete mellan ekologer, samhällsvetare, praktiker och andra intressenter i Barentsländerna.

Många av de arter som för närvarande finns söder om Barentsområdet kan kolonisera området i framtiden om miljöförhållandena blir lämpliga. De arter som kan komma att etablera sig i befintliga samhällen anses kunna innebära större utmaningar för inhemska arter än direkta klimateffekter. Även om inte alla dessa arter kan förväntas bli invasiva kan klimatförändringar komma att gynna invasionsförmågan. Invasiva främmande arter har varit en av de främsta anledningarna till tidigare artutrotningar och driver tillsammans med förlust av livsmiljöer dagens artutdöenden. Klimatdrivna artinvasioner kan omvandla ekosystemen i sådan grad att främmande arter blir dominanta och mångfalden av inhemska arter minskar. Vi förutsäger att ett antal skadedjur såsom vedlevande skalbaggar och fjärilar kan öka sin utbredning i framtiden. Dessutom anses några trädarter såsom pinjer (Pinus spp.) och silvergran (Abies alba) komma att bli vanligare och de klassificeras för närvarande som invasiva i delar av Barentsområdet.

Alla arter kan bli invasiva, dvs. de har potentialen att sprida sig över vidsträckta områden i stor mängd, oberoende av om de redan finns i Barentsområdet eller om de kommer att kunna etablera sig i framtiden. De kan också bidra till återhämtning av ekosystem genom att fullgöra viktiga ekosystemfunktioner eller genom att bidra med ekosystemtjänster när inhemska arter är sämre anpassade. Dessutom kan främmande arter komma att förlora sina ursprungliga utbredningsområden på grund av klimatförändring, vilket innebär att en yta de nyligen etablerat sig på är enda möjligheten till överlevnad. Enligt mångfaldskonventionen är främmande arter kostsamma för världens ekonomi, och kostnaden ökar sannolikt ännu mer framöver. Dilemman kring lämpligt bevarande och skötsel av arter kommer därför att bli vanligare, särskilt eftersom det inte är självklart hur man identifierar de arter som kommer att bli invasiva, och vilka som fullgör viktiga ekosystemfunktioner eller bidrar med ekosystemtjänster när inhemska arter blir sämre anpassade. Framtida forskning behöver således riktas in på att bedöma, art för art, om en introduktion har negativa eller positiva effekter på inhemska arter eller ekosystemfunktioner och ekosystemprocesser. Vi behöver veta och förstå deras inverkan och framtida roll i ekosystemen eftersom tillgångarna inte är oändliga. 


\section{References}

ACIA (2005). Arctic climate impact assessment. Cambridge Univ. Press, Cambridge.

Algar, A.C., Kharouba, H.M., Young, E.R. \& Kerr, J.T. (2009). Predicting the future of species diversity: macroecological theory, climate change, and direct tests of alternative forecasting methods. Ecography, Vol. 32, p. 22-33.

http://dx.doi.org/10.1111/j.1600-0587.2009.05832.x

Anderson, R.P. \& Raza, A. (2010). The effect of the extent of the study region on gis models of species geographic distributions and estimates of niche evolution: preliminary tests with montane rodents (genus Nephelomys) in Venezuela. J. Biogeogr. Vol. 37, p. 1378-1393. http://dx.doi.org/10.1111/j.13652699.2010.02290.x

Angerbjörn, A., Henttonen, H., Eide, N., Landa, A. \& Elmhagen, B. (2005). Saving the endangered Fennoscandian Alopex lagopus. Life03 Nat/S/000073 Interim Report. SEFALO+, Stockholm.

Angerbjörn, A., Henttonen, H., Eide, N.E., Landa, A., Norén, K. \& Meier, T. (2008). Saving the endangered Fennoscandian Alopex lagopus. Life 03 Nat/S/000073 final report. SEFALO+, Stockholm.

Angerbjörn, A., Tannerfeldt, M., Bjärvall, A., Ericson, M., From, J. \& Noren, E. (1995). Dynamics of the arctic fox population in Sweden. Ann. Zool. Fennici Vol. 32, p. 55-68.

Angerbjörn, A., Tannerfeldt, M. \& Erlinge, S. (1999). Predator-prey relationships: arctic foxes and lemmings. J. Anim. Ecol. Vol. 68, p. 34-49. http://dx.doi.org/10.1046/j.1365-2656.1999.00258.x

Aragón, P., Rodríguez, M.A., Olalla Tárraga, M.A. \& Lobo, J.M. (2010). Predicted impact of climate change on threatened terrestrial vertebrates in central Spain highlights differences between endotherms and ectotherms. Anim. Conserv. Vol. 13, p. 363-373. http://dx.doi.org/10.1111/j.1469-1795.2009.00343.x

Araújo, M.B., Alagador, D., Cabeza, M., Nogués-Bravo, D. \& Thuiller, W. (2011). Climate change threatens European conservation areas. Ecol. Lett. Vol. 14, p. 484-492. http://dx.doi.org/10.1111/j.1461-0248.2011.01610.x

Araújo, M.B. \& Luoto, M. (2007). The importance of biotic interactions for modelling species distributions under climate change. Glob. Ecol. Biogeogr. Vol. 16, p. 743-753. http://dx.doi.org/10.1111/j.1466-8238.2007.00359.x

Archaux, F. (2004). Breeding upwards when climate is becoming warmer: no bird response in the French Alps. Ibis Vol. 146, p. 138-144. http://dx.doi.org/10.1111/j.1474-919X.2004.00246.x

Bailey, E.P. (1992). Red foxes, Vulpes vulpes, as biological control agents for introduced arctic foxes, Alopex lagopus, on Alaskan islands. Can. Field-Naturalist. Vol. 106, p. 200-205.

Barclay, R.M.R., Baerwald, E.F. \& Gruver, J.C. (2007). Variation in bat and bird fatalities at wind energy facilities: assessing the effects of rotor size and tower height. Can. J. Zool. Vol. 85, p. 381-387. http://dx.doi.org/10.1139/Z07-011 
Barve, N., Barve, V., Jiménez-Valverde, A., Lira-Noriega, A., Maher, S.P., Peterson, A.T., Soberón, J. \& Villalobos, F. (2011). The crucial role of the accessible area in ecological niche modeling and species distribution modeling. Ecol. Model. Vol. 222, p. 1810-1819. http://dx.doi.org/10.1016/j.ecolmodel.2011.02.011

Baur, B. (1988). Microgeographical variation in shell size of the land snail Chondrina clienta. Biol. J. Linn. Soc. Vol. 35, p. 247-259. http://dx.doi.org/10.1111/j.10958312.1988.tb00469.x

Beebee, T.J.C. (1995). Amphibian breeding and climate. Nature Vol. 374, p. 219-220. http://dx.doi.org/10.1038/374219a0

Bellard, C., Bertelsmeier, C., Leadley, P., Thuiller, W. \& Courchamp, F. (2012). Impacts of climate change on the future of biodiversity. Ecol. Lett. Vol. 15, p. 365-377. http://dx.doi.org/10.1111/j.1461-0248.2011.01736.x

Berggren, L. (2005). Occurrence of Swiss stone pine (Pinus cembra) in a boreal forest landscape in relation to regeneration characteristics and habitat preferences by nutcrackers (Nucifraga caryocatactes). MSc thesis, Swedish Univ. Agricultural Sciences.

Berglind, S.-Å. (2007). Coenonympha hero. ArtDatabanken, Swedish Univ. Agricultural Sciences 2011-02-17.

Bertness, M.D. \& Coverdale, T.C. (2013). An invasive species facilitates the recovery of salt marsh ecosystems on Cape Cod. Ecology. Vol. 94, p. 1937-1943. http://dx.doi.org/10.1890/12-2150.1

Blaustein, A.R., Belden, L.K., Olson, D.H., Green, D.M., Root, T.L. \& Kiesecker, J.M. (2001) Amphibian breeding and climate change. Conserv. Biol. Vol. 15, p. 1804-1809 . http://dx.doi.org/10.1046/j.1523-1739.2001.00307.x

Braestrup, F.W. (1941). A study of the arctic fox in Greenland. Meddelelser om Grønland. Vol. 131, p. 1-101.

Bright, P.W. (1998). Behaviour of specialist species in habitat corridors: arboreal dormice avoid corridor gaps. Anim. Behav. Vol. 56, p. 1485-1490. http://dx.doi.org/10.1006/anbe.1998.0921

Brommer, J.E. (2004). The range margins of northern birds shift polewards. Ann. Zool. Fenn. Vol. 41, p. 391-397.

Brown A. and McLachlan, A. (2002). Sandy shore ecosystems and the threats facing them: some predictions for the year 2025. Env. Conserv. Vol. 29, p. 62-77. http://dx.doi.org/10.1017/S037689290200005X

Callaghan, T.V, Björn, L.O., Chernov, Y., Chapin, T., Christensen, T.R., Huntley, B., Ims, R.A., Johansson, M., Jolly, D. \& Jonasson, S. (2004). Biodiversity, distributions and adaptations of arctic species in the context of environmental change. AMBIO Vol. 33, p. 404-417.

Callaghan, T.V, Jonasson, S., Nichols, H., Heywood, R.B. \& Wookey, P.A. (1995). Arctic terrestrial ecosystems and environmental change [and discussion]. Philos. Trans. R. Soc. London. Ser. A Phys. Eng. Sci. Vol. 352, p. 259-276. http://rsta.royalsocietypublishing.org/content/352/1699/259.abstract

Carlquist, S.J., Janish, J.R. \& Papp, C.S. (1965). Island life: a natural history of the islands of the world. American Museum of Natural History.

Carroll, C., Dunk, J.R. \& Moilanen, A. (2010). Optimizing resiliency of reserve networks to climate change: multispecies conservation planning in the Pacific Northwest, USA. Glob. Change Biol. Vol. 16, p. 891-904. http://dx.doi.org/10.1111/j.1365-2486.2009.01965.x 
Carwardine, J., Wilson, K.A., Ceballos, G., Ehrlich, P.R., Naidoo, R., Iwamura, T., Hajkowicz, S.A. \& Possingham, H.P. (2008). Cost-effective priorities for global mammal conservation. Proc. Natl. Acad. Sci. Vol. 105, p. 11446-11450. http://dx.doi.org/10.1073/pnas.0707157105

Chown, S.L., Hoffmann, A.A., Kristensen, T.N., Angilletta Jr, M.J., Stenseth, N.C. \& C. Pertoldi (2010). Adapting to climate change: a perspective from evolutionary physiology. Clim. Res. Vol. 43, p. 3-15. http://dx.doi.org/10.3354/cr00879

Christiansen, E. \& Bakke, A. (1988). The spruce bark beetle of Eurasia. In: Dynamics of forest insect populations. Ed.: A.A. Berryman. New York: Plenum Press, p. 479-503. http://dx.doi.org/10.1007/978-1-4899-0789-9_23

Cornelissen, J.H.C., Callaghan, T.V., Alatalo, J.M., Michelsen, A., Graglia, E., Hartley, A.E., Hik, D.S., Hobbie, S.E., Press, M.C. \& Robinson, C.H. (2001). Global change and arctic ecosystems: is lichen decline a function of increases in vascular plant biomass? J. Ecol. Vol. 89, p. 984-994. http://dx.doi.org/10.1111/j.13652745.2001.00625.x

Crawford-Sidebotham, T.J. (1972). The influence of weather upon the activity of slugs. Oecologia, Vol. 9, p. 141-154. http://dx.doi.org/10.1007/BF00345879

Dalerum, F. \& Angerbjörn, A. (2000). Arctic fox (Alopex lagopus) diet in Karupelv valley, East Greenland, during a summer with low lemming density. Arctic, Vol. 53, p. 1-8. http://dx.doi.org/10.14430/arctic828

Daunt, F. \& Mitchell, I. (2013). Impacts of climate change on seabirds. MCCIP Science Review, 2013, p. 125-133.

Davis, M.B. \& Shaw, R.G. (2001). Range shifts and adaptive responses to quaternary climate change. Science, Vol. 292, p. 673-679. http://dx.doi.org/10.1126/science.292.5517.673

Deutsch, C.A., Tewksbury, J.J., Huey, R.B., Sheldon, K.S., Ghalambor, C.K., Haak, D.C. \& Martin, P.R. (2008). Impacts of climate warming on terrestrial ectotherms across latitude. Proc. Natl. Acad. Sci. Vol. 105, p. 6668-6672. http://dx.doi.org/10.1073/pnas.0709472105

Didier, L. (2001). Invasion patterns of european larch and Swiss stone pine in subalpine pastures in the French Alps. For. Ecol. Manage. Vol. 145, p. 67-77. http://dx.doi.org/10.1016/S0378-1127(00)00575-2

Drost, C.A. \& Fellers, G.M. (1996). Collapse of a regional frog fauna in the Yosemite area of the California Sierra Nevada, USA. Conserv. Biol. Vol. 10, p. 414-425. http://dx.doi.org/10.1046/j.1523-1739.1996.10020414.x

Eidmann, H.H. (1992). Impact of bark beetles on forests and forestry in Sweden. J. Appl. Entomol. Vol. 114, p. 193-200. http://dx.doi.org/10.1111/j.14390418.1992.tb01114.x

Elith, J., Phillips, S.J., Hastie, T., Dudík, M., Chee, Y.E. \& Yates, C.J. (2011). A statistical explanation of maxent for ecologists. Divers. Distrib. Vol. 17, p. 43-57. http://dx.doi.org/10.1111/j.1472-4642.2010.00725.x

Eliasson, C.U. (2012). Boloria improba. ArtDatabanken, Swedish Univ. Agricultural Sciences 2012-09-05.

Elling, W., Dittmar, C., Pfaffelmoser, K. \& Rötzer, T. (2009). Dendroecological assessment of the complex causes of decline and recovery of growth of silver fir (Abies alba Mill.) in Southern Germany. For. Ecol. Manage. Vol. 257, p. 1175-1187. http://dx.doi.org/10.1016/j.foreco.2008.10.014

Elmhagen, B., Tannerfeldt, M., Verucci, P. \& Angerbjörn, A. (2000). The arctic fox (Alopex lagopus): an opportunistic specialist. J. Zool. Vol. 251, p. 139-149. http://dx.doi.org/10.1111/j.1469-7998.2000.tb00599.x 
Elphick, J. (2007). The atlas of bird migration: tracing the great journeys of the world's birds. London: Natural History Museum.

Engler, R., Randin, C.F., Vittoz, P., Czaka, T., Beniston, M., Zimmermann, N.E. \& Guisan, A. (2009). Predicting future distributions of mountain plants under climate change: does dispersal capacity matter? Ecography, Vol. 32, p. 34-45. http://dx.doi.org/10.1111/j.1600-0587.2009.05789.x

Eriksson, M., Pouttu, A. \& Roininen, H. (2005). The influence of windthrow area and timber characteristics on colonization of wind-felled spruces by Ips typographus (L.). For. Ecol. Manage. Vol. 216, p. 105-116. http://dx.doi.org/10.1016/j.foreco.2005.05.044

Fielding, A.H., Whitfield, D.P. \& McLeod, D.R.A. (2006). Spatial association as an indicator of the potential for future interactions between wind energy developments and golden eagles Aquila chrysaetos in Scotland. Biol. Conserv. Vol. 131, p. 359-369. http://dx.doi.org/10.1016/j.biocon.2006.02.011

Fløjgaard, C., Morueta-Holme, N., Skov, F., Madsen, A.B. \& Svenning, J.C. (2009). Potential 21st century changes to the mammal fauna of Denmark: implications of climate change, land-use, and invasive species. In: IOP Conference Series: Earth and Environmental Science, IOP Publishing, 12016.

Fuglei, E. \& Ims, R.A. (2008). Global warming and effects on the arctic fox. Sci. Prog. Vol. 91, p. 175-191. http://dx.doi.org/10.3184/003685008X327468

Fuglei, E., \& Øritsland, N.A. (1999). Seasonal trends in body mass, food intake and resting metabolic rate, and induction of metabolic depression in arctic foxes (Alopex lagopus) at Svalbard. J. Comp. Physiol. B Biochem. Syst. Environ. Physiol. Vol. 169, p. 361-369. http://dx.doi.org/10.1007/s003600050232

Funk, W.C., Greene, A.E., Corn, P.S. \& Allendorf, F.W. (2005). High dispersal in a frog species suggests that it is vulnerable to habitat fragmentation. Biol. Lett. Vol. 1, p. 13-16. http://dx.doi.org/10.1098/rsbl.2004.0270

Gaston, K.J. \& Blackburn, T.M. (2002). Large-scale dynamics in colonization and extinction for breeding birds in Britain. J. Anim. Ecol. Vol. 71, p. 390-399. http://dx.doi.org/10.1046/j.1365-2656.2002.00607.x

Gent, A.H. \& Spellerberg, I.F. (1993). Movement rates of the smooth snake Coronella austriaca (Colubridae): a radiotelemetric study. Herpetol. J. Vol. 3, p. 140-146.

Gibbons, J.W., Scott, D.E., Ryan, T.J., Buhlmann, K.A., Tuberville, T.D., Metts, B.S., Greene, J.L., Mills, T., Leiden, Y., Poppy, S. \& Winne, C.T. (2000). The global decline of reptiles, déjà vu amphibians. BioScience, Vol. 50, p. 653-666. http://dx.doi.org/10.1641/0006-3568(2000)050[0653:TGDORD]2.0.C0;2

Gritti, E.S., Smith, B. \& Sykes, M.T. (2006). Vulnerability of Mediterranean basin ecosystems to climate change and invasion by exotic plant species. J. Biogeogr. Vol. 33, p. 145-157. http://dx.doi.org/10.1111/j.1365-2699.2005.01377.x

Hastie, T., Tibshirani, R. \& Friedman, J. (2009). The elements of statistical learning: data mining, inference and prediction. 27 Springer series in Statistics, 2nd ed. New York: Springer. http://dx.doi.org/10.1007/978-0-387-84858-7

Hausdorf, B. (2000). Biogeography of the Limacoidea Sensu Lato (Gastropoda: Stylommatophora): vicariance events and long distance dispersal. J. Biogeogr. Vol. 27, p. 379-390. http://dx.doi.org/10.1046/j.1365-2699.2000.00403.x

Henden, J.A., Ims, R.A., Yoccoz, N.G., Hellström, P. \& Angerbjörn, A. (2010). Strength of asymmetric competition between predators in food webs ruled by fluctuating prey: the case of foxes in tundra. Oikos, Vol. 119, p. 27-34. http://dx.doi.org/10.1111/j.1600-0706.2009.17604.x 
Herfindal, I., Linnell, J.D.C., Elmhagen, B., Andersen, R., Eide, N.E., Frafjord, K., Henttonen, H., Kaikusalo, A., Mela, M. \& Tannerfeldt, M. (2010). Population persistence in a landscape context: the case of endangered arctic fox populations in Fennoscandia. Ecography, Vol. 33, p. 932-941. http://dx.doi.org/10.1111/j.1600-0587.2009.05971.x

Hersteinsson, P., Landa, A., Eide, N.E., Linnell, J.D.C., Henttonnen, H., Tikhonov, A. \& Angerbjörn, A. (2006). Alopex lagopus. In IUCN 2011. IUCN Red List of Threatened Species. Version 2011.1.

Hersteinsson, P. \& Macdonald, D.W. (1992). Interspecific competition and the geographical distribution of red and arctic foxes Vulpes vulpes and Alopex lagopus. Oikos, Vol 64 p. 505-515. http://dx.doi.org/10.2307/3545168

Hickling, R., Roy, D.B., Hill, J.K., Fox, R. \& Thomas, C.D. (2006). The distributions of a wide range of taxonomic groups are expanding polewards. Glob. Change Biol. Vol. 12, p. 450-455. http://dx.doi.org/10.1111/j.1365-2486.2006.01116.x

Hill, J.K., Thomas, C.D., Fox, R., Telfer, M.G., Willis, S.G., Asher, J. \& Huntley, B. (2002). Responses of butterflies to twentieth century climate warming: implications for future ranges. Proc. R. Soc. B Biol. Sci. Vol. 269, p. 2163-2171.

Hof, A.R., Jansson, R. \& Nilsson, C. (2012a). Future climate change will favour nonspecialist mammals in the (Sub)arctics. Plos One, Vol. 7, p. E52574. http://dx.doi.org/10.1371/journal.pone.0052574

Hof, A.R., Jansson, R. \& Nilsson, C. (2012b). How biotic interactions may alter future predictions of species distributions: future threats to the persistence of the arctic fox in Fennoscandia. Divers. Distrib. Vol. 18, p. 554-562. http://dx.doi.org/10.1111/j.1472-4642.2011.00876.x

Hof, C., Levinsky, I., Araujo, M.B. \& Rahbek, C. (2011). Rethinking species' ability to cope with rapid climate change. Glob. Change Biol. Vol. 17, p. 2987-2990. http://dx.doi.org/10.1111/j.1365-2486.2011.02418.x

Hoffmann, M., Hilton-Taylor, C., Angulo, A., Böhm, M., Brooks, T.M., Butchart, S.H.M., Carpenter, K.E., Chanson, J., Collen, B., Cox, N.A., Darwall, W.R.T., Dulvy, N.K., Harrison, L.R., Katariya, V., Pollock, C.M., Quader, S., Richman, N.I., Rodrigues, A.S.L., Tognelli, M.F., Vié, J.-C., Aguiar, J.M., Allen, D.J., Allen, G.R., Amori, G., Ananjeva, N.B., Andreone, F., Andrew, P., Ortiz, A.L.A., Baillie, J.E.M., Baldi, R., Bell, B.D., Biju, S.D., Bird, J.P., Black-Decima, P., Blanc, J.J., Bolaños, F., Bolivar-G., W., Burfield, I.J., Burton, J.A., Capper, D.R., Castro, F., Catullo, G., Cavanagh, R.D., Channing, A., Chao, N.L., Chenery, A.M., Chiozza, F., Clausnitzer, V., Collar, N.J., Collett, L.C., Collette, B.B., Fernandez, C.F.C., Craig, M.T., Crosby, M.J., Cumberlidge, N., Cuttelod, A., Derocher, A.E., Diesmos, A.C., Donaldson, J.S., Duckworth, J.W., Dutson, G., Dutta, S.K., Emslie, R.H., Farjon, A., Fowler, S., Freyhof, J., Garshelis, D.L., Gerlach, J., Gower, D.J., Grant, T.D., Hammerson, G.A., Harris, R.B., Heaney, L.R., Hedges, S.B., Hero, J.-M., Hughes, B., Hussain, S.A., Icochea M., J., Inger, R.F., Ishii, N., Iskandar, D.T., Jenkins, R.K.B., Kaneko, Y., Kottelat, M., Kovacs, K.M., Kuzmin, S.L., La Marca, E., Lamoreux, J.F., Lau, M.W.N., Lavilla, E.O., Leus, K., Lewison, R.L., Lichtenstein, G., Livingstone, S.R., Lukoschek, V., Mallon, D.P., Mcgowan, P.J.K., Mcivor, A., Moehlman, P.D., Molur, S., Alonso, A.M., Musick, J.A., Nowell, K., Nussbaum, R.A., Olech, W., Orlov, N.L., Papenfuss, T.J., Parra-Olea, G., Perrin, W.F., Polidoro, B.A., Pourkazemi, M., Racey, P.A., Ragle, J.S., Ram, M., Rathbun, G., Reynolds, R.P., Rhodin, A.G.J., Richards, S.J., Rodríguez, L.O., Ron, S.R., Rondinini, C., Rylands, A.B., Sadovy de Mitcheson, Y., Sanciangco, J.C., Sanders, K.L., Santos-Barrera, G., Schipper, J., Self-Sullivan, C., Shi, Y., Shoemaker, A., Short, F.T., Sillero-Zubiri, C., Silvano, D.L., Smith, K.G., Smith, A.T., Snoeks, J., Stattersfield, A.J., Symes, A.J., Taber, A.B., Talukdar, B.K., Temple, H.J., Timmins, R., 
Tobias, J.A., Tsytsulina, K., Tweddle, D., Ubeda, C Valenti, ., S. V., Paul van Dijk, P., Veiga, L.M., Veloso, A., Wege, D.C., Wilkinson, M., Williamson, E.A., Xie, F., Young, B.E., Akçakaya, H.R., Bennun, L., Blackburn, T.M., Boitani, L., Dublin, H.T., da Fonseca, G.A.B., Gascon, C., Lacher, T.E., Mace, G.M., Mainka, S.A., McNeely, J.A., Mittermeier, R.A., Reid, G.M., Rodriguez, J.P., Rosenberg, A.A., Samways, M.J., Smart, J., Stein, B.A. \& Stuart, S.N. (2010). The impact of conservation on the status of the world's vertebrates. Science, Vol. 330, p. 1503-1509. http://dx.doi.org/10.1126/science.1194442

Houlahan, J. E., Findlay, C.S., Schmidt, B.R., Meyer, A.H. \& Kuzmin, S.L. (2000). Quantitative evidence for global amphibian population declines. Nature, Vol. 404, p. 752-755. http://dx.doi.org/10.1038/35008052

Hunt, W.G. (2002). Golden eagles in a perilous landscape: predicting the effects of mitigation for wind turbine blade-strike mortality. Consultant report to California Energy Commission under contract P500-02-043F, Public Interest Energy Research. California Energy Commission, Sacramento, USA.

Illner, H. (2011). Comments on the report Wind Energy Developments and Natura 2000. National Wind Watch.

IPCC (2007). IPCC fourth assessment report: climate change 2007 (AR4). Cambridge, UK and New York.

Jakt \& Jägare (2005). Mink tog hela fågelkolonin. Jakt \& Jägare, http://www.jaktojagare.se/mink-tog-hela-fagelkolonin

Janzen, F.J. (1994). Climate change and temperature-dependent sex determination in reptiles. Proc. Nat. Ac. Sci. Vol. 91, p. 7487-7490. http://dx.doi.org/10.1073/pnas.91.16.7487

Joubert, D. \& Bijlsma, R. (2010). Interplay between habitat fragmentation and climate change: inbreeding affects the response to thermal stress in Drosophila melanogaster. Clim. Res. Vol. 43, p. 57-70. http://dx.doi.org/10.3354/cr00883

Jönsson, A., Appelberg, G., Harding, S. \& Bärring, L. (2009). Spatio-temporal impact of climate change on the activity and voltinism of the spruce bark beetle, Ips typographus. Glob. Change Biol. Vol. 15, p. 486-499. http://dx.doi.org/10.1111/j.1365-2486.2008.01742.x

Kaikusalo, A. \& Angerbjörn, A. (1995). The arctic fox population in Finnish Lapland during 30 years, 1964-93. Ann. Zool. Fennici, Vol. 32, p. 69-77.

Karban, R. \& Strauss, S.Y. (2004). Physiological tolerance, climate change, and a northward range shift in the spittlebug, Philaenus. Ecol. Entomol. Vol. 29, p. 251-254. http://dx.doi.org/10.1111/j.1365-2311.2004.00576.x

Kiesecker, J.M., Blaustein, A.R. \& Belden, L.K. (2001). Complex causes of amphibian population declines. Nature, Vol. 410, p. 681-684. http://dx.doi.org/10.1038/35070552

Kullman, L. (2002). Rapid recent range-margin rise of tree and shrub species in the Swedish Scandes. J. Ecol. Vol. 90, p. 68-77. http://dx.doi.org/10.1046/j.00220477.2001.00630.x

Landergott, U., Holderegger, R., Kozlowski, G. \& Schneller, J.J. (2001). Historical bottlenecks decrease genetic diversity in natural populations of Dryopteris cristata. Heredity, Vol. 87, p. 344-355. http://dx.doi.org/10.1046/j.13652540.2001.00912.x

Lehtomäki, J. \& Moilanen, A. (2013). Methods and workflow for spatial conservation prioritization using Zonation. Env. Model. Softw. Vol. 47, p. 128-137. http://dx.doi.org/10.1016/j.envsoft.2013.05.001 
Liebhold, A.M. \& Tobin, P.C. (2008). Population ecology of insect invasions and their management. Annu. Rev. Entomol. Vol. 53, p. 387-408. http://dx.doi.org/10.1146/annurev.ento.52.110405.091401

Liu, C., Berry, P.M., Dawson, T.P. \& Pearson, R.G. (2005). Selecting thresholds of occurrence in the prediction of species distributions. Ecography. Vol. 28, p. 385-393. http://dx.doi.org/10.1111/j.0906-7590.2005.03957.x

Loarie, S.R., Duffy, P.B., Hamilton, H., Asner, G.P., Field, C.B. \& Ackerly, D.D. (2009). The velocity of climate change. Nature, Vol. 462, p. 1052-1055. http://dx.doi.org/10.1038/nature08649

López-López, P., Garcia-Ripollés, C., Soutullo, Á., Cadahia, L. \& Urios, V. (2007). Identifying potentially suitable nesting habitat for golden eagles applied to 'important bird areas' design. Anim. Conserv. Vol.10, p. 208-218. http://dx.doi.org/10.1111/j.1469-1795.2006.00089.x

Madders, M. \& Whitfield, D.P. (2006). Upland raptors and the assessment of wind farm impacts. Ibis, Vol. 148, p. 43-56. http://dx.doi.org/10.1111/j.1474919X.2006.00506.X

Mack, R.N., Simberloff, D., Lonsdale, W.M., Evans, H., Clout, M. \& Bazzaz, F.A. (2000). Biotic invasions: causes, epidemiology, global consequences, and control. Ecol. Appl. Vol. 10, p. 689-710. http://dx.doi.org/10.1890/10510761(2000)010[0689:BICEGC]2.0.C0;2

Markham, A. (1996). Potential impacts of climate change on ecosystems: a review of implications for policymakers and conservation biologists. Clim. Res. Vol. 6, p. 179-191. http://dx.doi.org/10.3354/cr006179

Mattes, H. (1994). Coevolutional aspects of stone pines and nutcracker. In: Proceedings of the International Workshop on Subalpine Stone Pines and Their Environment: the Status of Our Knowledge, INT-GTR 309 St. Moritz, Switzerland, 511 September 1992., eds.: W C Schmidt and F K Holtmeier. UT, USA: Intermountain Research Station, p. 31-35.

McLeod, D.R.A., Whitfield, D.P., Fielding, A.H., Haworth, P.F. \& McGrady, M.J. (2002). Predicting home range use by golden eagles Aquila chrysaetos in western Scotland. Avian Science, Vol. 2, p. 183-198.

Moilanen, A., Franco, A.M.A., Early, R., Fox, R., Wintle, B. \& Thomas, C.D. (2005). Prioritising multiple-use landscapes for conservation: methods for large multispecies planning problems. Proc. Roy. Soc. L. B. Vol. 272, p. 1885-1891. http://dx.doi.org/10.1098/rspb.2005.3164

Moilanen, A. \& Wintle, B.A. (2007). The boundary-quality penalty: a quantitative method for approximating species responses to fragmentation in reserve selection. Conserv. Biol. Vol. 21, p. 355-364. http://dx.doi.org/10.1111/j.15231739.2006.00625.x

Moilanen, A., Kujala, H. \& Leathwick, J. (2009). The zonation framework and software for conservation prioritization. In: Spatial Conservation Prioritization: Quantitative Methods and Computational Tools., eds.: A. Moilanen, K.A. Wilson, H.P. Possingham. Oxford University Press, Oxford, UK.

Morueta-Holme, N., Fløjgaard, C. \& Svenning, J.C. (2010). Climate change risks and conservation implications for a threatened small-range mammal species. Plos One, Vol. 5, p. E10360. http://dx.doi.org/10.1371/journal.pone.0010360

Moss, E. (2011). Golden eagle (Aquila chrysaetos) ecology and forestry. SLU Introductory Research Essay. Department of Wildlife, Fish, and Environmental Studies. Swedish Univ. Agricultural Sciences, Umeå, Sweden. 
Nakicenovic, N., Alcamo, J., Davis, G., De Vries, B., Fenhann, J., Gaffin, S., Gregory, K., Grubler, A., Jung, T.Y., Kram, T., La Rovere, E.L., Michaelis, L., Mori, S., Morita, T., Pepper, W., Pitcher, H.M., Price, L., Riahi, K., Roehrl, A., Rogner, H-H., Sankovski, A., Schlesinger, M., Shukla, P., Smith, S.J., Swart, R., Van Rooijen, S., Victor, N. \& Dadi, Z. (2000). Special report on emissions scenarios: a special report of Working Group III of the Intergovernmental Panel on Climate Change. Cambridge University Press, Cambridge.

Nilsson, C., Jansson, R., Keskitalo, E.C.H., Vlassova, T., Sutinen, M.L., Moen, J. \& Chapin, F.S. (2010). Challenges to adaptation in northernmost Europe as a result of global climate change. $A M B I O$, Vol. 39, p. 81-84. http://dx.doi.org/10.1007/s13280009-0010-y

Nordström, M., Högmander, J., Laine, J., Nummelin, J., Laanetu, N. \& Korpimäki, E. (2003). Effects of feral mink removal on seabirds, waders and passerines on small islands in the Baltic sea. Biol. Conserv. Vol. 109, p. 359-368. http://dx.doi.org/10.1016/S0006-3207(02)00162-3

Nyström, J., Ekenstedt, J., Angerbjörn, A., Thulin, L., Hellström, P. \& Dalén, L. (2006). Golden eagles on the Swedish mountain tundra: diet and breeding success in relation to prey fluctuations. Ornis Fenn. Vol. 83, p. 145-152.

Öhrn, P. (2012). 18 Introductory Research Essay. The spruce bark beetle Ips typographus in a changing climate - effects of weather conditions on the biology of Ips typographus. Thesis, Uppsala: Department of Ecology, Swedish Univ. Agricultural Sciences.

Opdam, P. \& Wascher, D. (2004). Climate change meets habitat fragmentation: linking landscape and biogeographical scale levels in research and conservation. Biol. Conserv. Vol. 117, p. 285-297. http://dx.doi.org/10.1016/j.biocon.2003.12.008

Orloff, S. \& Flannery, A. (1992). Wind turbine effects on avian activity, habitat use and mortality in Altamont Pass and Solano County Wind Resource Areas. Report to the Planning Departments of Alameda, Contra Costa and Solano Counties and the California Energy Commission, Grant No. 990-89-003 to BioSystems Analysis, Inc., Tiburon, CA.

Parmesan, C., Ryrholm, N., Stefanescu, C., Hill, J.K., Thomas, C.D., Descimon, H., Huntley, B., Kaila, L., Kullberg, J., Tammaru, T., Tennent, W.J., Thomas, J.A. \& Warren, M. (1999). Poleward shifts in geographical ranges of butterfly species associated with regional warming. Nature, Vol. 399, p. 579-583. http://dx.doi.org/10.1038/21181

Parmesan, C. \& Yohe, G. (2003). A globally coherent fingerprint of climate change impacts across natural systems. Nature, Vol. 421, p. 37-42. http://dx.doi.org/10.1038/nature01286

Peterson, A.T., Ortega-Huerta, M.A., Bartley, J., Sanchez-Cordero, V., Soberon, J., Buddemeier, R.H. \& Stockwell, D.R.B. (2002). Future projections for Mexican faunas under global climate change scenarios. Nature, Vol. 416, p. 626-629. http://dx.doi.org/10.1038/416626a

Phillips, S.J., Anderson, R.P. \& Schapire, R.E. (2006). Maximum entropy modeling of species geographic distributions. Ecol. Modell. Vol. 190, p. 231-259. http://dx.doi.org/10.1016/j.ecolmodel.2005.03.026

Pounds, J.A., Fogden, M.P.L. \& Campbell, J.H. (1999). Biological response to climate change on a tropical mountain. Nature, Vol. 398, p. 611-615. http://dx.doi.org/10.1038/19297 
Van der Putten, W.H., Macel, M. \& Visser, M.E. (2010). Predicting species distribution and abundance responses to climate change: why it is essential to include biotic interactions across trophic levels. Philos. Trans. R. Soc. B Biol. Sci. Vol. 365, p. 2025-2034.

R Core Development Team (2014). R: A language and environment for statistical computing. R Foundation for Statistical Computing: Vienna. URL: http://www.R-project.org/.

Riahi, K., Rao, S., Krey, V., Cho, C., Chirkov, V., Fischer, G., Kindermann, G., Nakicenovic, N. \& Rafaj, P. (2011). RCP 8.5: a scenario of comparatively high greenhouse gas emissions. Clim. Change, Vol. 109, p. 33-57. http://dx.doi.org/10.1007/s10584011-0149-y

Roderfeld, H., Blyth, E., Dankers, R., Huse, G., Slagstad, D., Ellingsen, I., Wolf, A. \& Lange, M.A. (2008). Potential impact of climate change on ecosystems of the Barents sea region. Clim. Change, Vol. 87, p. 283-303. http://dx.doi.org/10.1007/s10584-007-9350-4

Rodríguez-Castañeda, G., Hof, A.R., Jansson, R. \& Harding, L.E. (2012). Predicting the fate of biodiversity using species' distribution models: enhancing model comparability and repeatability. Plos One, Vol. 7, p. E44402. http://dx.doi.org/10.1371/journal.pone.0044402

Roques, A., Rabitsch, W., Rasplus, J.Y., Lopez-Vaamonde, C., Nentwig, W. \& Kenis, M. (2009). Alien terrestrial invertebrates of Europe. In: J.A. Drake, editor. Handbook of alien species in Europe. Springer Dordrecht; p. 63-79. http://dx.doi.org/10.1007/978-1-4020-8280-1_5

Sala, O.E., Chapin III, F.S., Armesto, J.J., Berlow, E., Bloomfield, J., Dirzo, R., HuberSanwald, E., Huenneke, L.F., Jackson, R.B., Kinzig, A., Leemans, R., Lodge, D.M., Mooney, H.A., Oesterheld, M., Leroy Poff, N., Sykes, M.T., Walker, B.H., Walker, M. $\&$ Wall, D.H. (2000). Global biodiversity scenarios for the year 2100. Science, Vol. 287, p. 1770-1774. http://dx.doi.org/10.1126/science.287.5459.1770

Sauvard, D. (2004). General biology of bark beetles. In: Bark wood boring insects in living trees in Europe: a synthesis. Springer, Dordrecht. p. 63-88. http://dx.doi.org/10.1007/978-1-4020-2241-8_7

Schlyter, P., Stjernquist, I., Bärring, L., Jönsson, A.M. \& Nilsson, C. (2006). Assessment of the impacts of climate change and weather extremes on boreal forests in northern europe, focusing on Norway spruce. Clim. Res. Vol. 31, p. 75-84. http://dx.doi.org/10.3354/cr031075

Selås, V. \& Vik, J.O. (2007). The arctic fox Alopex lagopus in Fennoscandia: a victim of human-induced changes in interspecific competition and predation? Biodivers. Conserv. Vol. 16, p. 3575-3583. http://dx.doi.org/10.1007/s10531-006-9118-6

Senn, J., Schonenberger, W. \& Wasem, U. (1994). Survival and growth of planted cembran pines at the alpine timberline. In: Proceedings of the International Workshop on subalpine stone pines and their environment: the status of our knowledge, INT-GTR 309, St. Moritz, Switzerland, 5-11 September 1992., eds.: Schmidt, W.C. \& Holtmeier, F.K.. UT, USA: Intermountain Research Station, 105-109.

Serreze, M.C., Maslanik, J.A., Scambos, T.A., Fetterer, F., Stroeve, J., Knowles, K., Fowler, C., Drobot, S., Barry, R.G. \& Haran, T.M. (2003). A record minimum arctic sea ice extent and area in 2002. Geophys. Res. Lett. Vol. 30, 1110. http://dx.doi.org/10.1029/2002GL016406

Serreze, M.C., Walsh, J.E., Chapin, F.S., Osterkamp, T., Dyurgerov, M., Romanovsky, V., Oechel, W.C., Morison, J., Zhang, T. \& Barry, R.G. (2000). Observational evidence of recent change in the northern high-latitude environment. Clim. Change, Vol. 46, p. 159-207. http://dx.doi.org/10.1023/A:1005504031923 
Smith, M.A. \& Green, D.M. (2005). Dispersal and the metapopulation paradigm in amphibian ecology and conservation: are all amphibian populations metapopulations?. Ecography, Vol. 28, p. 110-128. http://dx.doi.org/10.1111/j.0906-7590.2005.04042.x

Steenhof, K. \& Kochert, M.N. (1988). Dietary responses of three raptor species to changing prey densities in a natural environment. J. Anim. Ecol. Vol. 57, p. 37-48. http://dx.doi.org/10.2307/4761

Steenhof, K., Kochert, M.N. \& McDonald, T.L. (1997). Interactive effects of prey and weather on golden eagle reproduction. J. Anim. Ecol. Vol. 66, p. 350-362. http://dx.doi.org/10.2307/5981

Soja, A.J., Tchebakova, N.M., French, N.H., Flannigan, M.D., Shugart, H.H., Stocks, B.J., Sukhinin, A.I., Parfenova, E.I., Chapin III, F.S. \& Stackhouse Jr., P.W. (2007). Climateinduced boreal forest change: predictions versus current observations. Glob. Planet. Change, Vol. 56, p. 274-296. http://dx.doi.org/10.1016/j.gloplacha.2006.07.028

Sydeman, W.J., Thompson, S.A. \& Kitaysky, A. (2012). Seabirds and climate change: roadmap for the future. Marine Ecol. Prog. Ser. Vol. 454, p. 107-117. http://dx.doi.org/10.3354/meps09806

Systad, G., Nygård, T., Johnsen, T., Jacobsen, K.-O., Halley, D., Håkenrud, B., Østlyngen, A., Johansen, K., Bustnes, J.O. \& Strann, K.-B. (2007). Kongeørn i Finnmark 2001-2006. Norsk Institutt for Naturforskning Rapport, Vol. 236, p. 1-40.

Tannerfeldt, M., Elmhagen, B. \& Angerbjörn, A. (2002). Exclusion by interference competition? The relationship between red and arctic foxes. Oecologia, Vol. 132, p. 213-220. http://dx.doi.org/10.1007/s00442-002-0967-8

Thomas, C.D., Bodsworth, E.J., Wilson, R.J., Simmons, A.D., Davies, Z.G., Musche, M. \& Conradt, L. (2001). Ecological and evolutionary processes at expanding range margins. Nature, Vol. 411, p. 577-581. http://dx.doi.org/10.1038/35079066

Thomas, C.D., Cameron, A., Green, R.E., Bakkenes, M., Beaumont, L.J., Collingham, Y.C., Erasmus, B.F.N., Ferreira de Siqueira, M., Grainger, A. \& Hannah, L. (2004). Extinction risk from climate change. Nature, Vol. 427, p. 145-148. http://dx.doi.org/10.1038/nature02121

Thomas, C.D., Franco, A. \& Hill, J.K. (2006). Range retractions and extinction in the face of climate warming. Trends Ecol. Evol. Vol. 21, p. 415-416. http://dx.doi.org/10.1016/j.tree.2006.05.012

Thomson, A.M., Calvin, K.V., Smith, S.J., Kyle, G.P., Volke, A., Patel, P., Delgado-Arias, S., Bond-Lamberty, B., Wise, M.A., Clarke, L.E. \& Edmonds, J.A. (2011). RCP4. 5: a pathway for stabilization of radiative forcing by 2100. Clim. Change, Vol. 109, p. 77-94. http://dx.doi.org/10.1007/s10584-011-0151-4

Thuiller, W. (2004). Patterns and uncertainties of species' range shifts under climate change. Glob. Change Biol. Vol. 10, p. 2020-2027. http://dx.doi.org/10.1111/j.1365-2486.2004.00859.x

Thuiller, W., Brotons, L., Araújo, M.B. \& Lavorel, S. (2004). Effects of restricting environmental range of data to project current and future species distributions. Ecography. Vol. 27, p. 165-172. http://dx.doi.org/10.1111/j.09067590.2004.03673.x

Thulin, C.G. (2003). The distribution of mountain hares Lepus timidus in Europe: a challenge from brown hares L. europaeus?. Mamm. Rev. Vol. 33, p. 29-42. http://dx.doi.org/10.1046/j.1365-2907.2003.00008.x

Tjernberg, M. (1981). Diet of the golden eagle Aquila chrysaetos during the breeding season in Sweden. Ecography, Vol. 4, p. 12-19. http://dx.doi.org/10.1111/j.16000587.1981.tb00975.x 
Tjernberg, M. (1983). Habitat and nest site features of golden eagles (Aquila chrysaetos) in Sweden. Swedish Wild. Res. Vol. 12, p. 131-163.

Tjernberg, M. (2010). Nucifraga caryocatactes. Birds. ArtDatabanken, Swedish Univ. Agricultural Sciences 2011-12-22.

Tomback, D.F. \& Linhart, Y.B. (1990). The evolution of bird dispersed pines. Evol. Ecol. Vol. 4, p. 185-219. http://dx.doi.org/10.1007/BF02214330

Vagvolgyi, J. (1975). Body size, aerial dispersal, and origin of the pacific land snail fauna. Syst. Zool. Vol. 24, p. 465-488. http://dx.doi.org/10.2307/2412906

Virkkala, R., Marmion, M., Heikkinen, R.K., Thuiller, W. \& Luoto, M. (2010). Predicting range shifts of northern bird species: influence of modelling technique and topography. Acta Oecologica, Vol. 36, p. 269-281. http://dx.doi.org/10.1016/j.actao.2010.01.006

Walker, D., McGrady, M., McCluskie, A., Madders, M. \& McLeod, D.R.A. (2005). Resident golden eagle ranging behaviour before and after construction of a windfarm in Argyll. Scot. Birds, Vol. 25, p. 24-40.

Walther, G.R., Post, E., Convey, P., Menzel, A., Parmesan, C., Beebee, T.J.C., Fromentin, J.M., Hoegh-Guldberg, O. \& Bairlein, F. (2002). Ecological responses to recent climate change. Nature, Vol. 416, p. 389-395. http://dx.doi.org/10.1038/416389a

Walther, G.-R., Roques, A., Hulme, P.E., Sykes, M.T., Pyšek, P., Kühn, I., Zobel, M., Bacher, S., Botta-Dukát, Z. \& Bugmann, H. (2009). Alien species in a warmer world: risks and opportunities. Trends Ecol. Evol. Vol. 24, p. 686-693. http://dx.doi.org/10.1016/j.tree.2009.06.008

Warren, M.S., Hill, J.K., Thomas, J.A., Asher, J., Fox, R., Huntley, B., Roy, D.B., Telfer, M.G., Jeffcoate, S. \& Harding, P. (2001). Rapid responses of British butterflies to opposing forces of climate and habitat change. Nature, Vol. 414, p. 65-69. http://dx.doi.org/10.1038/35102054

Welter-Schultes, F.W (1998). Human-dispersed land snails in Crete, with special reference to Albinaria (Gastropoda: Clausiliidae). Biol. Gall. Vol. 24, p. 83-106.

Wermelinger, B. (2004). Ecology and management of the spruce bark beetle Ips typographus: a review of recent research. For. Ecol. Manage. Vol. 202, p. 67-82. http://dx.doi.org/10.1016/j.foreco.2004.07.018

Whitfield, D.P., McLeod, D.R.A., Fielding, A.H., Broad, R.A., Evans, R.J. \& Haworth, P.F. (2001). The effects of forestry on golden eagles on the island of Mull, western Scotland. J. Appl. Ecol. Vol. 38, p. 1208-1220. http://dx.doi.org/10.1046/j.00218901.2001.00675.x

Wolf, A., Callaghan, T.V. \& Larson, K. (2008). Future changes in vegetation and ecosystem function of the Barents region. Clim. Change, Vol. 87, p. 51-73. http://dx.doi.org/10.1007/s10584-007-9342-4

Woodward, F.I. (1987). Climate and plant distribution at global and local scales. Vegetatio, Vol. 69, p. 189-197. http://dx.doi.org/10.1007/BF00038700 


\section{Based on}

This report is largely based on the work contained in the following papers:

Chapter 5: Hof, A.R., Rodríguez Castañeda, G., Jansson, R. \& Nilsson, C. (In preparation) The vulnerability of birds breeding in the subarctic and arctic region.

Chapter 5.1: Buchadas, A.R.C. \& Hof, A.R. (In preparation). Future breeding and foraging sites of a locally endangered seabird.

Chapter 5.2: Cordier, C. (2012). Predicting the potential distribution of the golden eagle in Sweden in the face of future climate change in connection to wind power planning. MSC thesis, Umeå University, Umeå.

Chapter 5.3: Hof, A. R. (2014). Alien species in a warming climate: a case study of the nutcracker and stone pines. Biological Invasions. DOI: 10.1007/s10530-014-0813-z

Chapter 6: Hof, A.R. (2011). European terrestrial gastropod distribution. How may climate change affect their diversity and current distribution. In Gastropods: Diversity, habitat and genetics. Bianchi, A. , Fields, J. (Eds.). Hauppauge, New York: Nova Science Publishers, Inc.

Chapter 7.1: Hof, A.R. \& Svahlin, A. (In 2nd Review). The effect of climate change on the geographical distribution of insect pest species in the Swedish boreal forest. Scandinavian Journal of Forest Research.

Chapter 8: Hof, A.R., Jansson, R. \& Nilsson, C. (2012). Future climate change will favour non-specialist mammals in the (Sub)arctics. PLoS One, 7, e52574.

Chapter 8.1: Hof, A.R., Jansson, R. \& Nilsson, C. (2012). How biotic interactions may alter future predictions of species distributions: future threats to the persistence of the arctic fox in Fennoscandia. Diversity \& Distributions, 18, 554-562.

Chapter 10: Hof, A.R., Jansson, R. \& Nilsson, C. (In preparation) The subarctic and arctic region, a future species hotspot or a trap? 


\section{Appendix}

Table 2. The results of the assessment of the impact of climate change on the geographical distribution of a) amphibians, b) birds, c) butterflies and moths, d) mammals, and e) reptiles. Values are based on the average of ten models per species. Current: The percentage of the Barents Region currently climatically suitable for occurrence of the species. Future: The percentage of the Barents Region climatically suitable for the species in 2070 under the 4.5 Representative Concentration Pathway of the downscaled general circulation model HadGEM2-ES. Stable: The percentage of the Barents Region climatically suitable for the occurrence of the species currently and in 2070. Trend: $C$ = colonizer, $\mathrm{E}=$ extinct, $\mathrm{L}=$ loser, $\mathrm{U}=$ unable to colonize, $\mathrm{W}=$ winner. \% Change: The percentage range gain or loss. NA $=$ Not Applicable (when a species is able or unable to colonize).

a) Amphibians

\begin{tabular}{llrrrrr}
\hline Order & Species & Current & Future & Stable & Trend & \% Change \\
\hline Anura & Bufo bufo & $2 \%$ & $18 \%$ & $1 \%$ & W & $1,106 \%$ \\
Anura & Epidalea calamita & $0 \%$ & $0 \%$ & $0 \%$ & U & NA \\
Anura & Hyla arborea & $0 \%$ & $0 \%$ & $0 \%$ & U & NA \\
Anura & Pelophylax lessonae & $0 \%$ & $8 \%$ & $0 \%$ & C & NA \\
Anura & Rana arvalis & $2 \%$ & $21 \%$ & $1 \%$ & W & $783 \%$ \\
Anura & Rana dalmatina & $0 \%$ & $0 \%$ & $0 \%$ & U & NA \\
Anura & Rana temporaria & $2 \%$ & $19 \%$ & $2 \%$ & W & $1,049 \%$ \\
Caudata & Lissotriton vulgaris & $0 \%$ & $8 \%$ & $0 \%$ & C & NA \\
Caudata & Triturus cristatus & $0 \%$ & $7 \%$ & $0 \%$ & C & NA \\
\hline
\end{tabular}

b) Birds

\begin{tabular}{|c|c|c|c|c|c|c|}
\hline Order & Species & Current & Future & Stable & Trend & \% Change \\
\hline Accipitriformes & Accipiter gentilis & $2 \%$ & $25 \%$ & $2 \%$ & W & $1,300 \%$ \\
\hline Accipitriformes & Accipiter nisus & $1 \%$ & $52 \%$ & $1 \%$ & w & $4,221 \%$ \\
\hline Accipitriformes & Buteo buteo & $1 \%$ & $46 \%$ & $1 \%$ & w & $3,352 \%$ \\
\hline Accipitriformes & Buteo lagopus & $5 \%$ & $3 \%$ & $2 \%$ & $\mathrm{~L}$ & $-40 \%$ \\
\hline Accipitriformes & Circus aeruginosus & $1 \%$ & $42 \%$ & $1 \%$ & w & $7,258 \%$ \\
\hline Accipitriformes & Circus cyaneus & $0 \%$ & $18 \%$ & $0 \%$ & C & NA \\
\hline Accipitriformes & Haliaeetus albicilla & $3 \%$ & $7 \%$ & $2 \%$ & w & $118 \%$ \\
\hline Accipitriformes & Milvus migrans & $3 \%$ & $13 \%$ & $2 \%$ & w & $296 \%$ \\
\hline Accipitriformes & Milvus milvus & $0 \%$ & $0 \%$ & $0 \%$ & $u$ & NA \\
\hline Accipitriformes & Pandion haliaetus & $20 \%$ & $64 \%$ & $14 \%$ & W & $215 \%$ \\
\hline Accipitriformes & Pernis apivorus & $19 \%$ & $55 \%$ & $17 \%$ & W & $192 \%$ \\
\hline Anseriformes & Anas acuta & $2 \%$ & $20 \%$ & $1 \%$ & w & $1,075 \%$ \\
\hline Anseriformes & Anas crecca & $4 \%$ & $14 \%$ & $2 \%$ & w & $235 \%$ \\
\hline Anseriformes & Anas platyrhynchos & $7 \%$ & $19 \%$ & $3 \%$ & w & $176 \%$ \\
\hline Anseriformes & Anser anser & $0 \%$ & $13 \%$ & $0 \%$ & $\mathrm{C}$ & NA \\
\hline Anseriformes & Aythya ferina & $0 \%$ & $3 \%$ & $0 \%$ & $\mathrm{C}$ & NA \\
\hline Anseriformes & Aythya fuligula & $3 \%$ & $10 \%$ & $2 \%$ & W & $264 \%$ \\
\hline Anseriformes & Aythya marila & $7 \%$ & $30 \%$ & $4 \%$ & w & $360 \%$ \\
\hline Anseriformes & Branta canadensis & $1 \%$ & $36 \%$ & $1 \%$ & w & $3,693 \%$ \\
\hline Anseriformes & Bucephala clangula & $4 \%$ & $12 \%$ & $3 \%$ & w & $193 \%$ \\
\hline Anseriformes & Clangula hyemalis & $8 \%$ & $4 \%$ & $3 \%$ & $\mathrm{~L}$ & $-52 \%$ \\
\hline Anseriformes & Cygnus cygnus & $7 \%$ & $50 \%$ & $5 \%$ & W & $669 \%$ \\
\hline Anseriformes & Cygnus olor & $0 \%$ & $18 \%$ & $0 \%$ & $C$ & NA \\
\hline Anseriformes & Mareca penelope & $3 \%$ & $11 \%$ & $2 \%$ & w & $223 \%$ \\
\hline Anseriformes & Mareca strepera & $0 \%$ & $6 \%$ & $0 \%$ & $C$ & NA \\
\hline Anseriformes & Melanitta fusca & $5 \%$ & $30 \%$ & $4 \%$ & w & $494 \%$ \\
\hline
\end{tabular}




\begin{tabular}{|c|c|c|c|c|c|c|}
\hline Order & Species & Current & Future & Stable & Trend & $\%$ Change \\
\hline Anseriformes & Melanitta nigra & $3 \%$ & $1 \%$ & $0 \%$ & $\mathrm{~L}$ & $-64 \%$ \\
\hline Anseriformes & Mergellus albellus & $8 \%$ & $5 \%$ & $3 \%$ & $\mathrm{~L}$ & $-36 \%$ \\
\hline Anseriformes & Mergus merganser & $4 \%$ & $10 \%$ & $3 \%$ & w & $167 \%$ \\
\hline Anseriformes & Mergus serrator & $5 \%$ & $39 \%$ & $4 \%$ & W & $746 \%$ \\
\hline Anseriformes & Spatula clypeata & $0 \%$ & $34 \%$ & $0 \%$ & $\mathrm{C}$ & NA \\
\hline Anseriformes & Tadorna tadorna & $2 \%$ & $15 \%$ & $1 \%$ & w & $767 \%$ \\
\hline Caprimulgiformes & Apus apus & $2 \%$ & $5 \%$ & $1 \%$ & w & $153 \%$ \\
\hline Caprimulgiformes & Caprimulgus europaeus & $0 \%$ & $0 \%$ & $0 \%$ & $\mathrm{C}$ & NA \\
\hline Charadriiformes & Actitis hypoleucos & $2 \%$ & $3 \%$ & $1 \%$ & w & $15 \%$ \\
\hline Charadriiformes & Calidris alpina & $1 \%$ & $5 \%$ & $0 \%$ & w & $527 \%$ \\
\hline Charadriiformes & Calidris falcinellus & $9 \%$ & $56 \%$ & $7 \%$ & w & $510 \%$ \\
\hline Charadriiformes & Calidris pugnax & $32 \%$ & $44 \%$ & $19 \%$ & w & $38 \%$ \\
\hline Charadriiformes & Calidris temminckii & $4 \%$ & $11 \%$ & $2 \%$ & w & $194 \%$ \\
\hline Charadriiformes & Charadrius dubius & $0 \%$ & $59 \%$ & $0 \%$ & $\mathrm{C}$ & NA \\
\hline Charadriiformes & Charadrius hiaticula & $5 \%$ & $23 \%$ & $4 \%$ & w & $325 \%$ \\
\hline Charadriiformes & Gallinago gallinago & $3 \%$ & $7 \%$ & $1 \%$ & w & $175 \%$ \\
\hline Charadriiformes & Gallinago media & $4 \%$ & $14 \%$ & $0 \%$ & w & $275 \%$ \\
\hline Charadriiformes & Haematopus ostralegus & $1 \%$ & $50 \%$ & $1 \%$ & w & $4,219 \%$ \\
\hline Charadriiformes & Hydroprogne caspia & $1 \%$ & $66 \%$ & $1 \%$ & w & $4,573 \%$ \\
\hline Charadriiformes & Larus argentatus & $2 \%$ & $39 \%$ & $2 \%$ & w & $1,751 \%$ \\
\hline Charadriiformes & Larus canus & $4 \%$ & $27 \%$ & $4 \%$ & w & $581 \%$ \\
\hline Charadriiformes & Larus fuscus & $1 \%$ & $71 \%$ & $1 \%$ & w & $5,120 \%$ \\
\hline Charadriiformes & Larus marinus & $1 \%$ & $34 \%$ & $1 \%$ & w & $2,752 \%$ \\
\hline Charadriiformes & Larus minutus & $8 \%$ & $44 \%$ & $7 \%$ & w & $426 \%$ \\
\hline Charadriiformes & Larus ridibundus & $1 \%$ & $21 \%$ & $1 \%$ & w & $1,433 \%$ \\
\hline Charadriiformes & Limosa lapponica & $0 \%$ & $10 \%$ & $0 \%$ & $\mathrm{C}$ & NA \\
\hline Charadriiformes & Numenius arquata & $3 \%$ & $33 \%$ & $3 \%$ & w & $896 \%$ \\
\hline Charadriiformes & Numenius phaeopus & $5 \%$ & $6 \%$ & $2 \%$ & w & $12 \%$ \\
\hline Charadriiformes & Phalaropus lobatus & $46 \%$ & $55 \%$ & $25 \%$ & w & $19 \%$ \\
\hline Charadriiformes & Pluvialis squatarola & $11 \%$ & $29 \%$ & $6 \%$ & w & $157 \%$ \\
\hline Charadriiformes & Scolopax rusticola & $13 \%$ & $70 \%$ & $11 \%$ & w & $452 \%$ \\
\hline Charadriiformes & Stercorarius longicaudus & $24 \%$ & $3 \%$ & $2 \%$ & $\mathrm{~L}$ & $-87 \%$ \\
\hline Charadriiformes & Sterna hirundo & $21 \%$ & $51 \%$ & $16 \%$ & w & $143 \%$ \\
\hline Charadriiformes & Sterna paradisaea & $6 \%$ & $8 \%$ & $3 \%$ & w & $38 \%$ \\
\hline Charadriiformes & Tringa erythropus & $60 \%$ & $67 \%$ & $49 \%$ & w & $12 \%$ \\
\hline Charadriiformes & Tringa glareola & $52 \%$ & $77 \%$ & $47 \%$ & w & $48 \%$ \\
\hline Charadriiformes & Tringa ochropus & $12 \%$ & $29 \%$ & $8 \%$ & w & $147 \%$ \\
\hline Charadriiformes & Tringa totanus & $15 \%$ & $53 \%$ & $13 \%$ & w & $248 \%$ \\
\hline Charadriiformes & Vanellus vanellus & $1 \%$ & $17 \%$ & $1 \%$ & w & $1,399 \%$ \\
\hline Columbiformes & Columba oenas & $0 \%$ & $1 \%$ & $0 \%$ & $\mathrm{C}$ & NA \\
\hline Columbiformes & Columba palumbus & $3 \%$ & $54 \%$ & $3 \%$ & w & $1,816 \%$ \\
\hline Columbiformes & Streptopelia decaocto & $0 \%$ & $3 \%$ & $0 \%$ & $\mathrm{C}$ & NA \\
\hline Columbiformes & Streptopelia turtur & $11 \%$ & $84 \%$ & $11 \%$ & w & $664 \%$ \\
\hline Coraciiformes & Alcedo atthis & $0 \%$ & $1 \%$ & $0 \%$ & $\mathrm{C}$ & NA \\
\hline Cuculiformes & Cuculus canorus & $5 \%$ & $10 \%$ & $1 \%$ & w & $106 \%$ \\
\hline Falconiformes & Falco columbarius & $7 \%$ & $8 \%$ & $1 \%$ & w & $9 \%$ \\
\hline Falconiformes & Falco peregrinus & $1 \%$ & $55 \%$ & $1 \%$ & w & $4,107 \%$ \\
\hline Falconiformes & Falco subbuteo & $1 \%$ & $54 \%$ & $0 \%$ & w & $8,473 \%$ \\
\hline Falconiformes & Falco tinnunculus & $5 \%$ & $10 \%$ & $2 \%$ & w & $121 \%$ \\
\hline Galliformes & Bonasa bonasia & $4 \%$ & $9 \%$ & $2 \%$ & w & $101 \%$ \\
\hline Galliformes & Lagopus lagopus & $6 \%$ & $0 \%$ & $0 \%$ & $\mathrm{~L}$ & $-98 \%$ \\
\hline Galliformes & Lagopus muta & $10 \%$ & $16 \%$ & $4 \%$ & w & $54 \%$ \\
\hline Galliformes & Lyrurus tetrix & $4 \%$ & $4 \%$ & $1 \%$ & $\mathrm{~L}$ & $-4 \%$ \\
\hline Galliformes & Perdix perdix & $0 \%$ & $1 \%$ & $0 \%$ & $\mathrm{C}$ & NA \\
\hline Galliformes & Phasianus colchicus & $2 \%$ & $7 \%$ & $1 \%$ & w & $189 \%$ \\
\hline Galliformes & Tetrao urogallus & $5 \%$ & $1 \%$ & $0 \%$ & $\mathrm{~L}$ & $-90 \%$ \\
\hline Gaviiformes & Gavia arctica & $3 \%$ & $4 \%$ & $1 \%$ & w & $60 \%$ \\
\hline Gaviiformes & Gavia stellata & $4 \%$ & $8 \%$ & $2 \%$ & w & $125 \%$ \\
\hline Gruiformes & Crex crex & $0 \%$ & $3 \%$ & $0 \%$ & $\mathrm{C}$ & NA \\
\hline Gruiformes & Fulica atra & $0 \%$ & $6 \%$ & $0 \%$ & C & NA \\
\hline Gruiformes & Gallinula chloropus & $0 \%$ & $0 \%$ & $0 \%$ & $\mathrm{C}$ & NA \\
\hline Gruiformes & Grus grus & $2 \%$ & $4 \%$ & $1 \%$ & w & $71 \%$ \\
\hline Gruiformes & Porzana porzana & $3 \%$ & $66 \%$ & $3 \%$ & w & $1,800 \%$ \\
\hline
\end{tabular}




\begin{tabular}{|c|c|c|c|c|c|c|}
\hline Order & Species & Current & Future & Stable & Trend & $\%$ Change \\
\hline Gruiformes & Rallus aquaticus & $0 \%$ & $9 \%$ & $0 \%$ & C & NA \\
\hline Passeriformes & Acrocephalus dumetorum & $16 \%$ & $47 \%$ & $14 \%$ & w & $193 \%$ \\
\hline Passeriformes & Acrocephalus palustris & $0 \%$ & $20 \%$ & $0 \%$ & $C$ & NA \\
\hline Passeriformes & Acrocephalus schoenobaenus & $1 \%$ & $6 \%$ & $1 \%$ & W & $326 \%$ \\
\hline Passeriformes & Acrocephalus scirpaceus & $0 \%$ & $42 \%$ & $0 \%$ & $\mathrm{C}$ & NA \\
\hline Passeriformes & Aegithalos caudatus & $0 \%$ & $26 \%$ & $0 \%$ & c & NA \\
\hline Passeriformes & Alauda arvensis & $0 \%$ & $22 \%$ & $0 \%$ & c & NA \\
\hline Passeriformes & Anthus cervinus & $6 \%$ & $5 \%$ & $2 \%$ & L & $-20 \%$ \\
\hline Passeriformes & Anthus pratensis & $5 \%$ & $14 \%$ & $0 \%$ & w & $161 \%$ \\
\hline Passeriformes & Anthus trivialis & $3 \%$ & $15 \%$ & $2 \%$ & w & $375 \%$ \\
\hline Passeriformes & Bombycilla garrulus & $9 \%$ & $1 \%$ & $0 \%$ & L & $-91 \%$ \\
\hline Passeriformes & Carduelis cannabina & $0 \%$ & $9 \%$ & $0 \%$ & C & NA \\
\hline Passeriformes & Carduelis carduelis & $0 \%$ & $8 \%$ & $0 \%$ & $C$ & NA \\
\hline Passeriformes & Carduelis chloris & $2 \%$ & $10 \%$ & $1 \%$ & w & $484 \%$ \\
\hline Passeriformes & Carduelis flammea & $8 \%$ & $7 \%$ & $3 \%$ & L & $-14 \%$ \\
\hline Passeriformes & Carduelis hornemanni & $10 \%$ & $1 \%$ & $0 \%$ & $\mathrm{~L}$ & $-95 \%$ \\
\hline Passeriformes & Carduelis spinus & $4 \%$ & $15 \%$ & $3 \%$ & w & $326 \%$ \\
\hline Passeriformes & Carpodacus erythrinus & $1 \%$ & $16 \%$ & $1 \%$ & w & $1,653 \%$ \\
\hline Passeriformes & Certhia familiaris & $2 \%$ & $37 \%$ & $2 \%$ & w & $1,653 \%$ \\
\hline Passeriformes & Cinclus cinclus & $5 \%$ & $1 \%$ & $1 \%$ & L & $-72 \%$ \\
\hline Passeriformes & Coccothraustes coccothraustes & $0 \%$ & $30 \%$ & $0 \%$ & $\mathrm{C}$ & NA \\
\hline Passeriformes & Corvus corax & $5 \%$ & $6 \%$ & $1 \%$ & w & $19 \%$ \\
\hline Passeriformes & Corvus corone & $4 \%$ & $19 \%$ & $4 \%$ & w & $380 \%$ \\
\hline Passeriformes & Corvus frugilegus & $0 \%$ & $16 \%$ & $0 \%$ & $C$ & NA \\
\hline Passeriformes & Corvus monedula & $1 \%$ & $34 \%$ & $1 \%$ & w & $5,717 \%$ \\
\hline Passeriformes & Delichon urbicum & $2 \%$ & $7 \%$ & $2 \%$ & w & $188 \%$ \\
\hline Passeriformes & Emberiza citrinella & $2 \%$ & $25 \%$ & $2 \%$ & w & $1,223 \%$ \\
\hline Passeriformes & Emberiza hortulana & $3 \%$ & $13 \%$ & $3 \%$ & w & $356 \%$ \\
\hline Passeriformes & Emberiza rustica & $14 \%$ & $2 \%$ & $1 \%$ & L & $-89 \%$ \\
\hline Passeriformes & Emberiza schoeniclus & $3 \%$ & $7 \%$ & $1 \%$ & w & $144 \%$ \\
\hline Passeriformes & Eremophila alpestris & $5 \%$ & $0 \%$ & $0 \%$ & L & $-99 \%$ \\
\hline Passeriformes & Erithacus rubecula & $3 \%$ & $10 \%$ & $1 \%$ & w & $257 \%$ \\
\hline Passeriformes & Ficedula hypoleuca & $4 \%$ & $12 \%$ & $2 \%$ & w & $178 \%$ \\
\hline Passeriformes & Fringilla coelebs & $3 \%$ & $53 \%$ & $3 \%$ & w & $1,472 \%$ \\
\hline Passeriformes & Fringilla montifringilla & $11 \%$ & $6 \%$ & $3 \%$ & $\mathrm{~L}$ & $-50 \%$ \\
\hline Passeriformes & Garrulus glandarius & $2 \%$ & $4 \%$ & $0 \%$ & w & $122 \%$ \\
\hline Passeriformes & Hippolais icterina & $1 \%$ & $56 \%$ & $1 \%$ & w & $5,246 \%$ \\
\hline Passeriformes & Hirundo rustica & $2 \%$ & $32 \%$ & $1 \%$ & w & $1,215 \%$ \\
\hline Passeriformes & Lanius collurio & $0 \%$ & $9 \%$ & $0 \%$ & C & NA \\
\hline Passeriformes & Lanius excubitor & $6 \%$ & $32 \%$ & $2 \%$ & w & $448 \%$ \\
\hline Passeriformes & Locustella fluviatilis & $0 \%$ & $39 \%$ & $0 \%$ & C & NA \\
\hline Passeriformes & Locustella naevia & $0 \%$ & $11 \%$ & $0 \%$ & $\mathrm{C}$ & NA \\
\hline Passeriformes & Loxia curvirostra & $3 \%$ & $21 \%$ & $3 \%$ & w & $561 \%$ \\
\hline Passeriformes & Loxia leucoptera & $4 \%$ & $13 \%$ & $3 \%$ & w & $212 \%$ \\
\hline Passeriformes & Loxia pytyopsittacus & $3 \%$ & $17 \%$ & $3 \%$ & w & $430 \%$ \\
\hline Passeriformes & Lullula arborea & $0 \%$ & $4 \%$ & $0 \%$ & C & NA \\
\hline Passeriformes & Luscinia luscinia & $0 \%$ & $50 \%$ & $0 \%$ & $C$ & NA \\
\hline Passeriformes & Luscinia svecica & $22 \%$ & $56 \%$ & $10 \%$ & w & $154 \%$ \\
\hline Passeriformes & Motacilla alba & $3 \%$ & $15 \%$ & $2 \%$ & w & $419 \%$ \\
\hline Passeriformes & Motacilla cinerea & $0 \%$ & $12 \%$ & $0 \%$ & $C$ & NA \\
\hline Passeriformes & Motacilla flava & $7 \%$ & $13 \%$ & $3 \%$ & w & $94 \%$ \\
\hline Passeriformes & Muscicapa striata & $4 \%$ & $38 \%$ & $4 \%$ & w & $889 \%$ \\
\hline Passeriformes & Nucifraga caryocatactes & $1 \%$ & $21 \%$ & $0 \%$ & w & $1,720 \%$ \\
\hline Passeriformes & Oenanthe oenanthe & $4 \%$ & $6 \%$ & $1 \%$ & w & $47 \%$ \\
\hline Passeriformes & Panurus biarmicus & $0 \%$ & $1 \%$ & $0 \%$ & C & NA \\
\hline Passeriformes & Parus ater & $1 \%$ & $3 \%$ & $0 \%$ & w & $306 \%$ \\
\hline Passeriformes & Parus caeruleus & $1 \%$ & $17 \%$ & $0 \%$ & w & $1,377 \%$ \\
\hline Passeriformes & Parus cinctus & $53 \%$ & $12 \%$ & $8 \%$ & $\mathrm{~L}$ & $-78 \%$ \\
\hline Passeriformes & Parus cristatus & $2 \%$ & $29 \%$ & $2 \%$ & w & $1,097 \%$ \\
\hline Passeriformes & Parus major & $3 \%$ & $7 \%$ & $1 \%$ & w & $167 \%$ \\
\hline Passeriformes & Parus montanus & $4 \%$ & $12 \%$ & $3 \%$ & w & $160 \%$ \\
\hline Passeriformes & Parus palustris & $0 \%$ & $6 \%$ & $0 \%$ & C & NA \\
\hline Passeriformes & Passer domesticus & $2 \%$ & $29 \%$ & $2 \%$ & w & $1,477 \%$ \\
\hline
\end{tabular}




\begin{tabular}{|c|c|c|c|c|c|c|}
\hline Order & Species & Current & Future & Stable & Trend & \% Change \\
\hline Passeriformes & Passer montanus & $0 \%$ & $58 \%$ & $0 \%$ & C & NA \\
\hline Passeriformes & Perisoreus infaustus & $6 \%$ & $0 \%$ & $0 \%$ & $E$ & $-100 \%$ \\
\hline Passeriformes & Phoenicurus ochruros & $4 \%$ & $59 \%$ & $3 \%$ & W & $1,342 \%$ \\
\hline Passeriformes & Phylloscopus borealis & $81 \%$ & $18 \%$ & $16 \%$ & $\mathrm{~L}$ & $-77 \%$ \\
\hline Passeriformes & Phylloscopus collybita & $21 \%$ & $81 \%$ & $21 \%$ & W & $279 \%$ \\
\hline Passeriformes & Phylloscopus sibilatrix & $25 \%$ & $58 \%$ & $16 \%$ & W & $128 \%$ \\
\hline Passeriformes & Phylloscopus trochiloides & $28 \%$ & $73 \%$ & $25 \%$ & w & $162 \%$ \\
\hline Passeriformes & Pica pica & $2 \%$ & $12 \%$ & $1 \%$ & W & $485 \%$ \\
\hline Passeriformes & Plectrophenax nivalis & $25 \%$ & $0 \%$ & $0 \%$ & $\mathrm{~L}$ & $-98 \%$ \\
\hline Passeriformes & Pyrrhula pyrrhula & $5 \%$ & $6 \%$ & $2 \%$ & W & $28 \%$ \\
\hline Passeriformes & Regulus regulus & $3 \%$ & $39 \%$ & $2 \%$ & W & $1,043 \%$ \\
\hline Passeriformes & Riparia riparia & $32 \%$ & $26 \%$ & $9 \%$ & $\mathrm{~L}$ & $-19 \%$ \\
\hline Passeriformes & Saxicola rubetra & $15 \%$ & $39 \%$ & $9 \%$ & W & $154 \%$ \\
\hline Passeriformes & Sitta europaea & $0 \%$ & $3 \%$ & $0 \%$ & C & NA \\
\hline Passeriformes & Sturnus vulgaris & $5 \%$ & $40 \%$ & $5 \%$ & w & $652 \%$ \\
\hline Passeriformes & Sylvia atricapilla & $3 \%$ & $61 \%$ & $3 \%$ & W & $1,777 \%$ \\
\hline Passeriformes & Sylvia borin & $15 \%$ & $63 \%$ & $13 \%$ & w & $314 \%$ \\
\hline Passeriformes & Sylvia communis & $10 \%$ & $77 \%$ & $10 \%$ & w & $640 \%$ \\
\hline Passeriformes & Sylvia curruca & $31 \%$ & $54 \%$ & $29 \%$ & W & $72 \%$ \\
\hline Passeriformes & Tarsiger cyanurus & $45 \%$ & $0 \%$ & $0 \%$ & $E$ & $-100 \%$ \\
\hline Passeriformes & Troglodytes troglodytes & $1 \%$ & $9 \%$ & $1 \%$ & W & $701 \%$ \\
\hline Passeriformes & Turdus merula & $1 \%$ & $31 \%$ & $1 \%$ & W & $2,120 \%$ \\
\hline Passeriformes & Turdus pilaris & $5 \%$ & $33 \%$ & $4 \%$ & W & $535 \%$ \\
\hline Passeriformes & Turdus torquatus & $6 \%$ & $0 \%$ & $0 \%$ & $\mathrm{~L}$ & $-96 \%$ \\
\hline Pelecaniformes & Ardea cinerea & $1 \%$ & $21 \%$ & $1 \%$ & w & $2,901 \%$ \\
\hline Piciformes & Dendrocopos major & $2 \%$ & $7 \%$ & $0 \%$ & w & $284 \%$ \\
\hline Piciformes & Dryobates minor & $1 \%$ & $10 \%$ & $0 \%$ & W & $774 \%$ \\
\hline Piciformes & Dryocopus martius & $2 \%$ & $12 \%$ & $1 \%$ & W & $437 \%$ \\
\hline Piciformes & Jynx torquilla & $0 \%$ & $22 \%$ & $0 \%$ & $\mathrm{C}$ & NA \\
\hline Piciformes & Picoides tridactylus & $6 \%$ & $17 \%$ & $4 \%$ & W & $205 \%$ \\
\hline Piciformes & Picus canus & $2 \%$ & $34 \%$ & $2 \%$ & w & $1,820 \%$ \\
\hline Piciformes & Picus viridis & $0 \%$ & $3 \%$ & $0 \%$ & C & NA \\
\hline Podicipediformes & Podiceps auritus & $5 \%$ & $46 \%$ & $4 \%$ & w & $770 \%$ \\
\hline Podicipediformes & Podiceps cristatus & $0 \%$ & $4 \%$ & $0 \%$ & C & NA \\
\hline Podicipediformes & Podiceps grisegena & $2 \%$ & $10 \%$ & $1 \%$ & w & $439 \%$ \\
\hline Podicipediformes & Tachybaptus ruficollis & $0 \%$ & $4 \%$ & $0 \%$ & $\mathrm{C}$ & NA \\
\hline Procellariiformes & Fulmarus glacialis & $3 \%$ & $2 \%$ & $1 \%$ & $\mathrm{~L}$ & $-47 \%$ \\
\hline Strigiformes & Asio otus & $1 \%$ & $20 \%$ & $1 \%$ & W & $2,188 \%$ \\
\hline Strigiformes & Glaucidium passerinum & $1 \%$ & $1 \%$ & $0 \%$ & $\mathrm{~L}$ & $-46 \%$ \\
\hline Strigiformes & Strix aluco & $0 \%$ & $0 \%$ & $0 \%$ & U & NA \\
\hline Suliformes & Phalacrocorax carbo & $0 \%$ & $17 \%$ & $0 \%$ & C & NA \\
\hline
\end{tabular}

c) Butterflies and moths

\begin{tabular}{|c|c|c|c|c|c|c|}
\hline Order & Species & Current & Future & Stable & Trend & $\%$ Change \\
\hline Lepidoptera & Aglais io & $0 \%$ & $2 \%$ & $0 \%$ & $\mathrm{C}$ & NA \\
\hline Lepidoptera & Aglais urticae & $1 \%$ & $2 \%$ & $0 \%$ & W & $271 \%$ \\
\hline Lepidoptera & Anthocharis cardamines & $4 \%$ & $41 \%$ & $3 \%$ & W & $978 \%$ \\
\hline Lepidoptera & Aphantopus hyperantus & $33 \%$ & $24 \%$ & $9 \%$ & $\mathrm{~L}$ & $-25 \%$ \\
\hline Lepidoptera & Aporia crataegi & $1 \%$ & $15 \%$ & $0 \%$ & w & $2,621 \%$ \\
\hline Lepidoptera & Argynnis adippe & $0 \%$ & $11 \%$ & $0 \%$ & $\mathrm{C}$ & NA \\
\hline Lepidoptera & Argynnis aglaja & $1 \%$ & $16 \%$ & $1 \%$ & W & $1,621 \%$ \\
\hline Lepidoptera & Argynnis paphia & $1 \%$ & $28 \%$ & $1 \%$ & w & $2,887 \%$ \\
\hline Lepidoptera & Aricia artaxerxes & $7 \%$ & $3 \%$ & $0 \%$ & $\mathrm{~L}$ & $-56 \%$ \\
\hline Lepidoptera & Aricia eumedon & $10 \%$ & $30 \%$ & $3 \%$ & w & $208 \%$ \\
\hline Lepidoptera & Aricia nicias & $0 \%$ & $12 \%$ & $0 \%$ & C & NA \\
\hline Lepidoptera & Boloria aquilonaris & $19 \%$ & $29 \%$ & $10 \%$ & w & $55 \%$ \\
\hline Lepidoptera & Boloria eunomia & $34 \%$ & $12 \%$ & $6 \%$ & $\mathrm{~L}$ & $-64 \%$ \\
\hline Lepidoptera & Boloria euphrosyne & $4 \%$ & $7 \%$ & $1 \%$ & w & $77 \%$ \\
\hline Lepidoptera & Boloria freija & $14 \%$ & $14 \%$ & $4 \%$ & Stable & $0 \%$ \\
\hline Lepidoptera & Boloria frigga & $21 \%$ & $14 \%$ & $4 \%$ & $\mathrm{~L}$ & $-32 \%$ \\
\hline
\end{tabular}




\begin{tabular}{|c|c|c|c|c|c|c|}
\hline Order & Species & Current & Future & Stable & Trend & \% Change \\
\hline Lepidoptera & Boloria improba & $3 \%$ & $0 \%$ & $0 \%$ & $E$ & $-100 \%$ \\
\hline Lepidoptera & Boloria napaea & $8 \%$ & $0 \%$ & $0 \%$ & $E$ & $-100 \%$ \\
\hline Lepidoptera & Boloria selene & $14 \%$ & $23 \%$ & $2 \%$ & W & $67 \%$ \\
\hline Lepidoptera & Boloria thore & $13 \%$ & $0 \%$ & $0 \%$ & $\mathrm{~L}$ & $-97 \%$ \\
\hline Lepidoptera & Brenthis ino & $2 \%$ & $9 \%$ & $1 \%$ & w & $401 \%$ \\
\hline Lepidoptera & Callophrys rubi & $8 \%$ & $7 \%$ & $0 \%$ & $\mathrm{~L}$ & $-5 \%$ \\
\hline Lepidoptera & Carterocephalus palaemon & $10 \%$ & $52 \%$ & $6 \%$ & w & $423 \%$ \\
\hline Lepidoptera & Carterocephalus silvicola & $2 \%$ & $5 \%$ & $1 \%$ & W & $178 \%$ \\
\hline Lepidoptera & Celastrina argiolus & $17 \%$ & $66 \%$ & $14 \%$ & w & $283 \%$ \\
\hline Lepidoptera & Coenonympha arcania & $0 \%$ & $0 \%$ & $0 \%$ & $U$ & NA \\
\hline Lepidoptera & Coenonympha hero & $9 \%$ & $0 \%$ & $0 \%$ & $\mathrm{E}$ & $-100 \%$ \\
\hline Lepidoptera & Coenonympha pamphilus & $0 \%$ & $0 \%$ & $0 \%$ & $U$ & NA \\
\hline Lepidoptera & Coenonympha tullia & $18 \%$ & $19 \%$ & $7 \%$ & w & $5 \%$ \\
\hline Lepidoptera & Colias hecla & $1 \%$ & $12 \%$ & $0 \%$ & w & $1,230 \%$ \\
\hline Lepidoptera & Colias palaeno & $7 \%$ & $10 \%$ & $1 \%$ & w & $58 \%$ \\
\hline Lepidoptera & Colias werdandi & $7 \%$ & $0 \%$ & $0 \%$ & $E$ & $-100 \%$ \\
\hline Lepidoptera & Cupido minimus & $0 \%$ & $1 \%$ & $0 \%$ & $C$ & NA \\
\hline Lepidoptera & Cyaniris semiargus & $8 \%$ & $43 \%$ & $2 \%$ & w & $429 \%$ \\
\hline Lepidoptera & Erebia embla & $35 \%$ & $7 \%$ & $0 \%$ & $\mathrm{~L}$ & $-81 \%$ \\
\hline Lepidoptera & Erebia ligea & $9 \%$ & $14 \%$ & $4 \%$ & w & $69 \%$ \\
\hline Lepidoptera & Erebia pandrose & $6 \%$ & $0 \%$ & $0 \%$ & $\mathrm{E}$ & $-100 \%$ \\
\hline Lepidoptera & Erynnis tages & $0 \%$ & $1 \%$ & $0 \%$ & c & NA \\
\hline Lepidoptera & Euphydryas iduna & $11 \%$ & $0 \%$ & $0 \%$ & E & $-100 \%$ \\
\hline Lepidoptera & Favonius quercus & $0 \%$ & $1 \%$ & $0 \%$ & C & NA \\
\hline Lepidoptera & Glaucopsyche alexis & $0 \%$ & $2 \%$ & $0 \%$ & 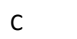 & NA \\
\hline Lepidoptera & Gonepteryx rhamni & $1 \%$ & $15 \%$ & $1 \%$ & w & $1,849 \%$ \\
\hline Lepidoptera & Hesperia comma & $0 \%$ & $0 \%$ & $0 \%$ & $C$ & NA \\
\hline Lepidoptera & Hipparchia semele & $0 \%$ & $2 \%$ & $0 \%$ & c & NA \\
\hline Lepidoptera & Issoria lathonia & $0 \%$ & $3 \%$ & $0 \%$ & C & NA \\
\hline Lepidoptera & Lasiommata maera & $0 \%$ & $7 \%$ & $0 \%$ & c & NA \\
\hline Lepidoptera & Lasiommata megera & $0 \%$ & $2 \%$ & $0 \%$ & $C$ & NA \\
\hline Lepidoptera & Lasiommata petropolitana & $6 \%$ & $6 \%$ & $1 \%$ & W & $7 \%$ \\
\hline Lepidoptera & Leptidea reali & $0 \%$ & $3 \%$ & $0 \%$ & $C$ & NA \\
\hline Lepidoptera & Leptidea sinapis & $4 \%$ & $13 \%$ & $1 \%$ & w & $220 \%$ \\
\hline Lepidoptera & Limenitis populi & $2 \%$ & $14 \%$ & $1 \%$ & w & $755 \%$ \\
\hline Lepidoptera & Lycaena helle & $6 \%$ & $2 \%$ & $0 \%$ & $\mathrm{~L}$ & $-58 \%$ \\
\hline Lepidoptera & Lycaena hippothoe & $0 \%$ & $12 \%$ & $0 \%$ & $C$ & NA \\
\hline Lepidoptera & Lycaena phlaeas & $2 \%$ & $11 \%$ & $0 \%$ & w & $406 \%$ \\
\hline Lepidoptera & Lycaena virgaureae & $4 \%$ & $67 \%$ & $4 \%$ & w & $1,540 \%$ \\
\hline Lepidoptera & Maniola jurtina & $0 \%$ & $0 \%$ & $0 \%$ & $U$ & NA \\
\hline Lepidoptera & Melitaea athalia & $0 \%$ & $4 \%$ & $0 \%$ & c & NA \\
\hline Lepidoptera & Melitaea cinxia & $0 \%$ & $1 \%$ & $0 \%$ & C & NA \\
\hline Lepidoptera & Melitaea diamina & $0 \%$ & $0 \%$ & $0 \%$ & $C$ & NA \\
\hline Lepidoptera & Nymphalis antiopa & $4 \%$ & $58 \%$ & $3 \%$ & w & $1,505 \%$ \\
\hline Lepidoptera & Ochlodes sylvanus & $1 \%$ & $8 \%$ & $0 \%$ & w & $1,225 \%$ \\
\hline Lepidoptera & Oeneis jutta & $25 \%$ & $15 \%$ & $4 \%$ & $\mathrm{~L}$ & $-41 \%$ \\
\hline Lepidoptera & Oeneis norna & $7 \%$ & $11 \%$ & $2 \%$ & w & $64 \%$ \\
\hline Lepidoptera & Papilio machaon & $0 \%$ & $5 \%$ & $0 \%$ & C & NA \\
\hline Lepidoptera & Pararge aegeria & $0 \%$ & $21 \%$ & $0 \%$ & $C$ & NA \\
\hline Lepidoptera & Parnassius apollo & $4 \%$ & $27 \%$ & $2 \%$ & w & $539 \%$ \\
\hline Lepidoptera & Pieris brassicae & $0 \%$ & $20 \%$ & $0 \%$ & $c$ & NA \\
\hline Lepidoptera & Pieris napi & $1 \%$ & $41 \%$ & $1 \%$ & w & $4792 \%$ \\
\hline Lepidoptera & Pieris rapae & $0 \%$ & $16 \%$ & $0 \%$ & C & NA \\
\hline Lepidoptera & Plebejus argus & $0 \%$ & $0 \%$ & $0 \%$ & 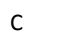 & NA \\
\hline Lepidoptera & Plebejus idas & $1 \%$ & $3 \%$ & $0 \%$ & w & $78 \%$ \\
\hline Lepidoptera & Plebejus optilete & $1 \%$ & $3 \%$ & $1 \%$ & w & $143 \%$ \\
\hline Lepidoptera & Polygonia c-album & $1 \%$ & $12 \%$ & $0 \%$ & w & $1,275 \%$ \\
\hline Lepidoptera & Polyommatus amandus & $0 \%$ & $8 \%$ & $0 \%$ & C & NA \\
\hline Lepidoptera & Polyommatus icarus & $2 \%$ & $31 \%$ & $1 \%$ & w & $1,301 \%$ \\
\hline Lepidoptera & Pyrgus alveus & $1 \%$ & $68 \%$ & $1 \%$ & w & $4,638 \%$ \\
\hline Lepidoptera & Pyrgus andromedae & $9 \%$ & $0 \%$ & $0 \%$ & $\mathrm{E}$ & $-100 \%$ \\
\hline Lepidoptera & Pyrgus centaureae & $45 \%$ & $14 \%$ & $7 \%$ & $\mathrm{~L}$ & $-70 \%$ \\
\hline Lepidoptera & Pyrgus malvae & $1 \%$ & $12 \%$ & $0 \%$ & w & $2,047 \%$ \\
\hline
\end{tabular}




\begin{tabular}{llrrrrr}
\hline Order & Species & Current & Future & Stable & Trend & \% Change \\
\hline Lepidoptera & Satyrium w-album & $0 \%$ & $1 \%$ & $0 \%$ & C & NA \\
Lepidoptera & Thecla betulae & $0 \%$ & $21 \%$ & $0 \%$ & C & NA \\
Lepidoptera & Thymelicus lineola & $1 \%$ & $10 \%$ & $1 \%$ & W & $817 \%$ \\
Lepidoptera & Vanessa atalanta & $1 \%$ & $25 \%$ & $1 \%$ & W & $3,559 \%$ \\
Lepidoptera & Vanessa cardui & $2 \%$ & $45 \%$ & $1 \%$ & W & $2,746 \%$ \\
\hline
\end{tabular}

d) Mammals

\begin{tabular}{|c|c|c|c|c|c|c|}
\hline Order & Species & Current & Future & Stable & Trend & $\%$ Change \\
\hline Carnivora & Dama dama & $0 \%$ & $7 \%$ & $0 \%$ & C & NA \\
\hline Carnivora & Lepus europaeus & $0 \%$ & $15 \%$ & $0 \%$ & C & NA \\
\hline Carnivora & Myotis brandtii & $0 \%$ & $27 \%$ & $0 \%$ & C & NA \\
\hline Carnivora & Myotis daubentonii & $0 \%$ & $18 \%$ & $0 \%$ & C & NA \\
\hline Carnivora & Myotis mystacinus & $0 \%$ & $1 \%$ & $0 \%$ & C & NA \\
\hline Carnivora & Myotis nattereri & $0 \%$ & $3 \%$ & $0 \%$ & C & NA \\
\hline Carnivora & Oryctolagus cuniculus & $0 \%$ & $19 \%$ & $0 \%$ & C & NA \\
\hline Carnivora & Pipistrellus pygmaeus & $0 \%$ & $2 \%$ & $0 \%$ & C & NA \\
\hline Carnivora & Plecotus auritus & $0 \%$ & $14 \%$ & $0 \%$ & C & NA \\
\hline Carnivora & Vespertilio murinus & $0 \%$ & $1 \%$ & $0 \%$ & C & NA \\
\hline Cetartiodactyla & Canis lupus & $6 \%$ & $3 \%$ & $2 \%$ & $\mathrm{~L}$ & $-43 \%$ \\
\hline Cetartiodactyla & Martes martes & $12 \%$ & $65 \%$ & $10 \%$ & w & $440 \%$ \\
\hline Cetartiodactyla & Neomys fodiens & $35 \%$ & $67 \%$ & $31 \%$ & w & $90 \%$ \\
\hline Cetartiodactyla & Sorex minutus & $4 \%$ & $75 \%$ & $4 \%$ & w & $1,669 \%$ \\
\hline Cetartiodactyla & Ursus arctos & $43 \%$ & $87 \%$ & $40 \%$ & w & $100 \%$ \\
\hline Chiroptera & Apodemus flavicollis & $8 \%$ & $6 \%$ & $0 \%$ & $\mathrm{~L}$ & $-15 \%$ \\
\hline Chiroptera & Apodemus sylvaticus & $0 \%$ & $37 \%$ & $0 \%$ & $\mathrm{C}$ & NA \\
\hline Chiroptera & Arvicola amphibius & $1 \%$ & $65 \%$ & $1 \%$ & w & $7,099 \%$ \\
\hline Chiroptera & Castor fiber & $1 \%$ & $30 \%$ & $0 \%$ & w & $4,248 \%$ \\
\hline Chiroptera & Eptesicus nilssonii & $0 \%$ & $64 \%$ & $0 \%$ & $\mathrm{C}$ & NA \\
\hline Chiroptera & Gulo gulo & $43 \%$ & $13 \%$ & $11 \%$ & L & $-69 \%$ \\
\hline Chiroptera & Lemmus lemmus & $6 \%$ & $0 \%$ & $0 \%$ & $\mathrm{~L}$ & $-94 \%$ \\
\hline Chiroptera & Lynx lynx & $25 \%$ & $7 \%$ & $1 \%$ & $\mathrm{~L}$ & $-73 \%$ \\
\hline Chiroptera & Meles meles & $0 \%$ & $29 \%$ & $0 \%$ & C & NA \\
\hline Chiroptera & Micromys minutus & $1 \%$ & $1 \%$ & $0 \%$ & $\mathrm{~L}$ & $-21 \%$ \\
\hline Chiroptera & Muscardinus avellanarius & $0 \%$ & $0 \%$ & $0 \%$ & $U$ & NA \\
\hline Chiroptera & Mustela erminea & $35 \%$ & $31 \%$ & $21 \%$ & $\mathrm{~L}$ & $-11 \%$ \\
\hline Chiroptera & Myotis dasycneme & $0 \%$ & $0 \%$ & $0 \%$ & U & NA \\
\hline Eulipotyphla & Eptesicus serotinus & $0 \%$ & $0 \%$ & $0 \%$ & $U$ & NA \\
\hline Eulipotyphla & Nyctalus leisleri & $0 \%$ & $0 \%$ & $0 \%$ & U & NA \\
\hline Eulipotyphla & Nyctalus noctula & $0 \%$ & $0 \%$ & $0 \%$ & C & NA \\
\hline Eulipotyphla & Pipistrellus nathusii & $0 \%$ & $0 \%$ & $0 \%$ & $U$ & NA \\
\hline Lagomorpha & Cervus elaphus & $1 \%$ & $6 \%$ & $1 \%$ & W & $975 \%$ \\
\hline Lagomorpha & Pteromys volans & $1 \%$ & $4 \%$ & $0 \%$ & w & $430 \%$ \\
\hline Lagomorpha & Sus scrofa & $1 \%$ & $5 \%$ & $0 \%$ & w & $725 \%$ \\
\hline Rodentia & Alces alces & $4 \%$ & $46 \%$ & $2 \%$ & w & $917 \%$ \\
\hline Rodentia & Capreolus capreolus & $1 \%$ & $27 \%$ & $1 \%$ & w & $2,376 \%$ \\
\hline Rodentia & Erinaceus europaeus & $3 \%$ & $34 \%$ & $3 \%$ & w & $1,167 \%$ \\
\hline Rodentia & Lepus timidus & $15 \%$ & $36 \%$ & $7 \%$ & w & $138 \%$ \\
\hline Rodentia & Lutra lutra & $8 \%$ & $49 \%$ & $8 \%$ & w & $498 \%$ \\
\hline Rodentia & Microtus agrestis & $3 \%$ & $19 \%$ & $1 \%$ & w & $503 \%$ \\
\hline Rodentia & Mus musculus & $6 \%$ & $26 \%$ & $3 \%$ & W & $307 \%$ \\
\hline Rodentia & Mustela nivalis & $5 \%$ & $55 \%$ & $5 \%$ & w & $909 \%$ \\
\hline Rodentia & Myodes glareolus & $6 \%$ & $32 \%$ & $3 \%$ & w & $387 \%$ \\
\hline Rodentia & Sciurus vulgaris & $1 \%$ & $12 \%$ & $1 \%$ & w & $947 \%$ \\
\hline Rodentia & Sorex araneus & $4 \%$ & $25 \%$ & $3 \%$ & w & $463 \%$ \\
\hline Rodentia & Vulpes vulpes & $2 \%$ & $42 \%$ & $2 \%$ & w & $1,774 \%$ \\
\hline
\end{tabular}


e) Reptiles

\begin{tabular}{llrrrrr}
\hline Order & Species & Current & Future & Stable & Trend & \% Change \\
\hline Squamata & Anguis fragilis & $3 \%$ & $47 \%$ & $3 \%$ & W & $1,441 \%$ \\
Squamata & Coronella austriaca & $0 \%$ & $12 \%$ & $0 \%$ & C & NA \\
Squamata & Lacerta agilis & $0 \%$ & $1 \%$ & $0 \%$ & C & NA \\
Squamata & Natrix natrix & $0 \%$ & $42 \%$ & $0 \%$ & C & NA \\
Squamata & Vipera berus & $16 \%$ & $57 \%$ & $15 \%$ & W & $252 \%$ \\
Squamata & Zootoca vivipara & $42 \%$ & $82 \%$ & $40 \%$ & W & $96 \%$ \\
\hline
\end{tabular}


Nordic Council of Ministers

Ved Stranden 18

DK-1061 Copenhagen K

www.norden.org

Future of biodiversity in the Barents Region

Climate change may affect biodiversity to a large extent. Its effects have already caused shifts in species distributions and even species extinctions. Since especially high latitude regions are expected to be affected, this publication assesses the impact of future climate change on the biodiversity in the Barents Region (northern parts of Norway, Sweden and Finland, and Northwest Russia). It reports on the impact of climate change on a large range of species, including amphibians, butterflies, birds, mammals, moths, plants, slugs, snails, and reptiles, of which a few were studied more in depth. It further identifies future hotspots of species diversity and gives recommendations on species that should be prioritized for conservation and on areas that should be included in the network of protected areas in future. Lastly, it provides guidance on which aspects require further study

TemaNord 2015:519

ISBN 978-92-893-3988-9 (PRINT)

ISBN 978-92-893-3990-2 (PDF)

ISBN 978-92-893-3989-6 (EPUB)

ISSN 0908-6692 